Prepared for the U.S. Department of Energy

under Contract DE-AC05-76RL01830

\title{
High-Performance Buildings - Value, Messaging, Financial and Policy Mechanisms
}

MJ McCabe

February 2011

Pacific Northwest

NATIONAL LABORATORY

Proudly Operated by Battelle Since 1965 


\title{
DISCLAIMER
}

This report was prepared as an account of work sponsored by an agency of the United States Government. Neither the United States Government nor any agency thereof, nor Battelle Memorial Institute, nor any of their employees, makes any warranty, express or implied, or assumes any legal liability or responsibility for the accuracy, completeness, or usefulness of any information, apparatus, product, or process disclosed, or represents that its use would not infringe privately owned rights. Reference herein to any specific commercial product, process, or service by trade name, trademark, manufacturer, or otherwise does not necessarily constitute or imply its endorsement, recommendation, or favoring by the United States Government or any agency thereof, or Battelle Memorial Institute. The views and opinions of authors expressed herein do not necessarily state or reflect those of the United States Government or any agency thereof.

\author{
PACIFIC NORTHWEST NATIONAL LABORATORY \\ operated by \\ BATTELLE \\ for the \\ UNITED STATES DEPARTMENT OF ENERGY \\ under Contract DE-AC05-76RL01830
}

Printed in the United States of America
Available to DOE and DOE contractors from the Office of Scientific and Technical Information,

\footnotetext{
Available to the public from the National Technical Information Service, U.S. Department of Commerce, 5285 Port Royal Rd., Springfield, VA 22161 ph: (800) 553-6847 fax: $(703) 605-6900$ email: orders@ntis.fedworld.gov online ordering: http://www.ntis.gov/ordering.htm
}

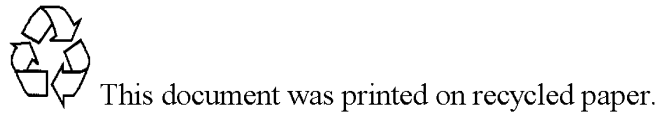




\section{High-Performance Buildings - Value, Messaging, Financial and Policy Mechanisms}

MJ McCabe ${ }^{1}$

February 2011

Prepared for

the U.S. Department of Energy

under Contract DE-AC05-76RL01830

Pacific Northwest National Laboratory

Richland, Washington 99352

\footnotetext{
${ }^{1}$ HaydenTanner, LLC, Bigfork, Montana.
} 


\begin{abstract}
At the request of the Pacific Northwest National Laboratory, an in-depth analysis of the rapidly evolving state of real estate investments, high-performance building technology, and interest in efficiency was conducted by HaydenTanner, LLC, for the U.S. Department of Energy (DOE) Building Technologies Program.

The analysis objectives were

- to evaluate the link between high-performance buildings and their market value

- to identify core messaging to motivate owners, investors, financiers, and others in the real estate sector to appropriately value and deploy high-performance strategies and technologies across new and existing buildings

- to summarize financial mechanisms that facilitate increased investment in these buildings.

To meet these objectives, work consisted of a literature review of relevant writings, examination of existing and emergent financial and policy mechanisms, interviews with industry stakeholders, and an evaluation of the value implications through financial modeling.

This report documents the analysis methodology and findings, conclusion and recommendations. Its intent is to support and inform the DOE Building Technologies Program on policy and program planning for the financing of high-performance new buildings and building retrofit projects.
\end{abstract}




\section{Summary}

Investment in high-performance building lags behind the available technology. So why aren't more property owners and investors taking action?

The perceived market risks of doing energy efficiency are greater than any potential benefits. Many in the commercial building sector believe there is a significant cost premium associated with the design and construction of high-performance buildings. ${ }^{1}$

This report will support and inform the U.S. Department of Energy (DOE) Building Technologies Program (BTP) on policy and program planning for the financing of high-performance new buildings and building retrofit projects. The objectives of this analysis are to

1. Evaluate the link between high-performance buildings and their market value.

2. Identify core messaging to motivate owners, investors, financiers, and others in the real estate sector to appropriately value and deploy high-performance strategies and technologies across new and existing buildings.

3. Summarize financial mechanisms that facilitate increased investment in these buildings.

To meet these objectives, we reviewed relevant writings, examined existing and emergent financial and policy mechanisms, interviewed industry stakeholders, and evaluated the value implications through financial modeling.

Findings from the completed analysis include, but are not limited to, the following:

- Current technology is capable of delivering substantial efficiency. However, technology alone cannot solve the problem.

- While there is an increasing level of consciousness around energy efficiency, this does not reflect a concrete commitment to actual investment in, or implementation of, efficiency or highperformance measures.

- The equipment must be purchased, installed, and properly run for efficiency to be realized.

- Deployment is accelerated with the right mix of financial tools.

- Direct funding for efficiency retrofits is neither sustainable nor scaleable; tactics must leverage a range of options.

- Deployment must incorporate a multidisciplinary approach and collectively address the issues of finance, investment, and incentives; metrics and verification; operations and maintenance; awareness, education, and training; design and construction; and the energy and utility landscape.

- For real estate investors, owners, and financiers, investment analysis and decision-making are led by traditional bottom-line factors such as revenue, expenses, risk, and return, rather than by the narrower life-cycle cost analysis.

\footnotetext{
${ }^{1}$ Adapted from the Commercial Buildings Integration Multi-Year Program Plan FY 2010-2015 Opportunities and Gaps, excerpt on Financing.
} 
- Real estate investment decisions are multi-faceted and complex. Different owner strata have differing motivations. Decisions involve numerous stakeholders with both competing and complementary objectives. To be successful, solutions and messaging must directly address value and bottom-line results.

- Value considerations are important in framing the message.

- Broadly speaking, the industry judges the market risks associated with high-performance attributes to be greater than potential benefits. This judgment is based partly in reality and partly on cultural barriers, business norms, and competing stakeholder interests.

- The perception of value depends on the stakeholders, investment objectives, access to and cost of capital, property type, and lease structure.

- To monetize energy savings, the savings must be bankable. To be bankable, the investment community must believe the efficiency is meaningful and will be persistent over time, or else they will not invest in or finance the improvements.

- Monitoring and verification, ongoing commissioning, and robust maintenance are critical. Through metering and response, they provide transparency and enable persistent efficiency, increasing stability and continuity and reducing uncertainty over time.

- There is a need to create partnerships between disparate groups with competing agendas and differing financial and regulatory incentives. Partnership creation includes engaging the regulated utility market and addressing inherent complexities that serve to dampen rather than promote investment in efficiency.

- To forge common understanding and shared objectives, language needs to be broadened to incorporate financial and energy metrics in the same medium; for example, cost per kilowatt-hour needs to be translated easily to cost per square foot.

To support and encourage investment in and deployment of high-performance measures in all building classes, both quickly and at scale, DOE needs to engage real estate professionals on the basis of financial returns over the holding period of the property and include a wide variety of inputs beyond energy or resource cost. The following criteria must be addressed:

- value proposition that articulates the link between efficiency and returns

- leadership modeled and best practices publicized

- clear action steps that set the framework for success

- transparency and certainty around energy use and efficiency performance

- persistence of high-performance measures over time

- education/training tailored for key stakeholders such as occupants, operators, and investors

- investment/financing that values high performance and efficiency as a bankable asset

- ease and simplicity of solutions that make adoption of high-performance measures effortless. 
Many of these needs can be addressed effectively by DOE alone, or in partnership to promote investments in high-performance buildings. Needs-driven promotion efforts include, but are not limited to, the following:

- Facilitate (and publicize) retrofit pilot projects between property owners, utilities, and financing sources, incorporating high-performance measures and investment vehicles, which ascribe value to resource efficiency.

- Develop a set of consistent, agreed-upon standardized metrics and valuation methodology so that properties can be evaluated across the sector, allowing for comparison between assets and enhancing uniform lending and investment strategies.

- Develop a prototype "energy usage sticker" to provide a visible indicator of usage, thereby impacting tenant and occupant interest in building performance and demand for high-performance buildings.

- Partner with industry organizations to present tailored and targeted training for major stakeholder groups, such as the Building Owners and Managers Association, Urban Land Institute, Institute of Real Estate Managers, National Association of State Energy Officials, and the American Bankers Association. For example, for property owner organizations, training should focus on how to reduce risk and maximize value impact through efficiency measures. For real estate managers, attention would be on best practices for monitoring and verification of performance and maintaining persistence through operations and management protocols.

- Develop databases to collect and disseminate meaningful performance and valuation data on highperformance buildings, allowing real estate professionals to compare properties more effectively and ultimately allowing for data to be standardized, risk analyzed, and financial market mechanisms crafted.

The allocation of capital and financing remain critical components in deploying the necessary technology and are significant impediments to seeing substantial investment in high-performance attributes. Hurdles can be pivotal and include a lack of data, first cost, capital versus operating budgets, risk exposure, the low ratio of energy costs to total operating expenses, high transaction costs, discount factor issues, and the inadequacy of traditional financing mechanisms for energy efficiency projects. Further complicating investment decisions are the large number of small to mid-sized buildings, wide geographic dispersion, and varying regional incentives. While some companies and property owners see the value of energy efficiency and choose to finance projects from their own budgets/accounts, others look at their available capital and make a different choice. The decision to invest is not necessarily tied to the decision to seek outside financing.

Several new and reformulated ideas are emerging to facilitate the movement of investment capital to the sector. The most promising of these financing structures aim to monetize energy efficiency, identify new types of collateral and means of ensuring repayment, and extend financing terms to address long payback periods. For commercial property, they include

- on-bill financing (OBF) - A utility company (or some other entity) finances the energy efficiency improvements. The property owner receives the benefit of the efficiency reduction in the form of a partial reduction in his monthly utility bill, with the balance between the actual savings and the rate payment used to amortize the improvements plus interest. The obligation runs with the property, is attached to the utility bill, and would be passed along to subsequent purchasers 
- energy and efficiency services agreements (ESAs) - An ESA requires no up-front capital from the commercial property owner; third-party financing cover all project costs. The provider initiates and maintains the contractual relationship with the efficiency retrofit contractor and handles ongoing management of the systems. The client continues to pay the energy bill plus an energy services payment to the provider, who takes a fee for managing the process and repays the debt and equity. The combined net payment is intended to be equal to or less than the pre-retrofit energy cost.

- property-assessed clean energy (PACE) - A municipality loans money to owners to make improvements to their property. To secure the loan, a lien is placed on the property in the form of an additional property tax assessment. Liens are repaid via an add-on to the property tax bill at an established rate of interest over a specific period, generally 20 years. The lien remains with the property, even upon sale, until fully repaid. The lien sits in priority to the property's first mortgage.

In conclusion, the DOE Building Technologies Program can act as a catalyst to deploy energy efficiency and high-performance buildings. While we have the technology to achieve increased efficiency, we have to speak the real estate industry's language and address their financial concerns in order to be successful. 


\section{Acknowledgments}

The state of real estate investments, high-performance building technology, and the interest in efficiency, particularly deep efficiency, continues to evolve rapidly. Competing priorities, increased complexity, changing regulations, and the competitive environment mean business practices are constantly evolving. This report provides a window onto the current landscape. Special thanks must be given Diane Vrkic (Waypoint Building Group), Theddi Wright-Chappell (Cushman \& Wakefield), David Wood (Initiative for Responsible Investment, Harvard University), Kim Fowler (Pacific Northwest National Laboratory), and most significantly to Dave Hunt (Pacific Northwest National Laboratory), who helped guide me through the changing circumstances - answering questions, providing updates on new legislation and shifting programs - and reviewed this document with an eye toward accuracy, clarity, and comprehensive coverage of relevant issues. Many others through the course of this work contributed greatly of their time and expertise - property owners, appraisers, investors, lenders, engineers, architects, those in the private sector, and those in the public sector, non-profits, and the utility industry. To each of you, I offer my profound gratitude. 


\section{Abbreviations and Acronyms}

\begin{tabular}{|c|c|}
\hline ASHRAE & American Society of Heating, Refrigerating and Air-Conditioning Engineers \\
\hline BEPC & Building Energy Performance Contract \\
\hline BOMA & Building Owners and Managers Association \\
\hline ВTP & DOE Building Technologies Program \\
\hline CAFÉ & Corporate Average Fuel Economy \\
\hline CBD & climate benefit districts \\
\hline CBIF & climate benefit increment financing \\
\hline CCI & Clinton Climate Initiative \\
\hline CCX & Chicago Climate Exchange \\
\hline $\mathrm{CDM}$ & Clean Development Mechanism \\
\hline CER & certified emissions reduction \\
\hline $\mathrm{CO}_{2}$ & carbon dioxide \\
\hline CSR & corporate social responsibility \\
\hline $\mathrm{DCF}$ & discounted cash flow \\
\hline DEC & display energy certificate \\
\hline DOE & U.S. Department of Energy \\
\hline EECBG & Energy Efficiency and Conservation Block Grant \\
\hline eePPA ${ }^{\mathrm{TM}}$ & Energy efficiency power purchase agreement \\
\hline EIA & U.S. Energy Information Administration \\
\hline EPA & U.S. Environmental Protection Agency \\
\hline EPC & energy performance certificate \\
\hline EPCRA & Emergency Planning and Community Right-to-Know Act \\
\hline ESA & efficiency or energy services agreement \\
\hline ESCO & energy services company \\
\hline ESPC & energy services performance contract \\
\hline ETS & energy trading scheme \\
\hline EU & European Union \\
\hline FOMC & Federal Open Market Committee \\
\hline GAO & U.S. Government Accountability Office \\
\hline HUD & U.S. Department of Housing and Urban Development \\
\hline HVAC & heating, ventilating, and air conditioning \\
\hline LBNL & Lawrence Berkeley National Laboratory \\
\hline LCCA & life-cycle cost analysis \\
\hline LEED & Leadership in Energy and Environmental Design \\
\hline LTV & loan-to-value (ratio) \\
\hline $\mathrm{M} \& \mathrm{~V}$ & measurement and verification \\
\hline
\end{tabular}


MESA

MUSH

MYPP

NAESCO

NNN

NOI

NRDC

NREL

O\&M

OBF

PACE

PNNL

PPA

PR

REALpac

REC

REIT

RESPA

RGGI

TAF

$\mathrm{tCO}_{2} \mathrm{e}$

UCC

UK

USGBC

WBCSD managed energy services agreement

municipalities (state/local governments), universities, K-12 schools, and hospitals Commercial Buildings Integration Multi-Year Program Plan FY 2010-2015

National Association of Energy Service Companies

triple net lease

net operating income

Natural Resources Defense Council

National Renewable Energy Laboratory

operations and maintenance

on-bill pay or on-bill financing

property-assessed clean energy

Pacific Northwest National Laboratory

power purchase agreement

public relations

Real Property Association of Canada

renewable and energy efficiency certificate/credit

real estate investment trust

Real Estate Settlement Procedures Act

Regional Greenhouse Gas Initiative

Toronto Atmospheric Fund

1 ton of greenhouse gas emissions

Uniform Commercial Code

United Kingdom

U.S. Green Building Council

World Business Council for Sustainable Development 


\section{Glossary}

absorption period - The period of time it takes for a building to reach fully leased status.

bankable - A project or proposal that has sufficient collateral, future cash flow, and high probability of success to be acceptable to institutional lenders for financing.

basis points - One hundredth of a percentage point ( $0.01 \%)$; used to measure the change in financial returns such as interest rates; 100 basis points $=1 \%$.

capitalization rate - The percentage number used to determine the current value of a property based on estimated future operating income. Net operating income/property value $=$ the cap rate. The higher the cap rate, the greater risk the investor perceives with the property returns.

churn - The costs associated with moving tenants and/or re-leasing space after a tenant vacates. This includes the period of time the space remains unoccupied with no rental income as well as the cost of brokerage commissions and tenant improvements.

Community Reinvestment Act - An act of Congress enacted in 1977 with the intention of encouraging depository institutions to help meet the credit needs of surrounding communities (particularly low- and moderate-income neighborhoods).

competitive (economic) obsolescence - Occurs when the property owner can no longer earn a fair rate of return on the ownership/operation of the subject property. As referenced to high-performance properties, this is due to more efficient or "greener" competing properties. (Current thinking here is that buildings with no ratings or lower Energy Star or LEED ratings will be less competitive than their peers with higher ratings.)

corporate social responsibility (CSR) - "Corporate social responsibility is the continuing commitment by business to contribute to economic development while improving the quality of life of the workforce and their families as well as the community and society at large" (World Business Council for Sustainable Development).

discount rate - The required rate of return as dictated by the most likely set of market rate investors; the rate of return an investor will apply to the cash flows of the property over the anticipated investment hold period. The higher the discount rate, the higher the risk an investor perceives in the cash flows and, consequently, the lower the net present value of the property.

display energy certificate (DEC) - In the UK, a DEC is required to be posted for larger public buildings. The DEC reflects the energy usage of the particular building and should be displayed at all times in a prominent place clearly visible to the public. They are accompanied by an Advisory Report that lists cost-effective measures to improve the energy rating of the building.

energy performance certificate - The certificate provides energy efficiency A-G ratings and recommendations for improvement. The ratings - similar to those found on consumer products such as refrigerators - are standardized so the energy efficiency of one building can easily be compared with another building of a similar type. These are required on all property sales and leases. 
full-service gross lease - A lease in which the stated rent includes the operating expenses (including utilities) and taxes for the building. It is the opposite of a net lease (NNN).

lease-up - The process of leasing space to full occupancy in a building. The period of time it takes to reach full lease up is called the "absorption period".

Leadership in Energy and Environmental Design (LEED) - Green building ratings provided by the U.S. Green Building Council (USGBC).

loan to value - The ratio between the value of an asset as compared to the amount of debt that is (or could) finance it. Generally speaking, the higher the loan to value, the greater the risk to the lending institution.

net lease - A lease requiring the tenant to pay in addition to a fixed rental, the expenses of the property, such as utilities, taxes, insurance, maintenance, cleaning. The tenant is responsible for the payment of these costs either directly or as additional rent. Opposite of a full-service gross lease.

net operating income - Income (in an investment property - rental income) after deducting operating expenses (e.g., utilities, janitorial, supplies, accounting, management, maintenance) for the property but before interest and taxes.

net present value - Includes the outflow and inflow of cash (the cost and benefits) as well as the time value of money.

public relations - The art or science of establishing and promoting a positive relationship with the public.

real estate investment trust - A corporation or trust that uses pooled investor capital to buys and manages shares in a real estate portfolio, direct real estate or real estate loans. A REIT can be one of three types: a listed public REIT, which trades on a public stock exchange, an unlisted/non-exchange traded REIT, or a private REIT. REITs enjoy certain tax benefits and must distribute out $95 \%$ of their annual earnings to shareholders. The United States Congress created the REIT concept in 1960.

vacancy factor - A normalized number applied to a financial model to calculate average vacancy for a specific property over time. (Buildings are naturally vacant for some period of time over the course of their operations, either for retrofit or between tenants.) 


\section{Contents}

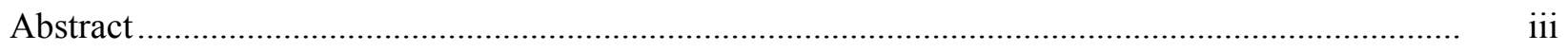

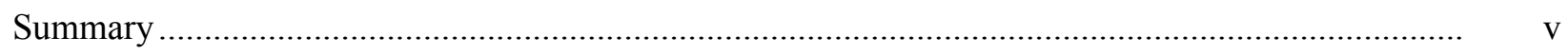

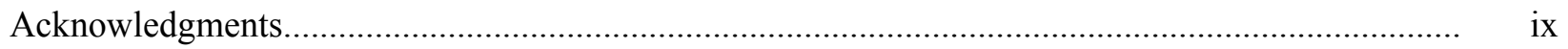

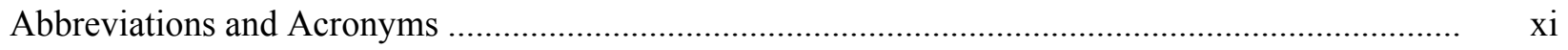

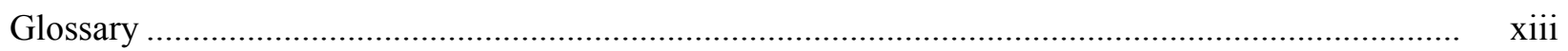

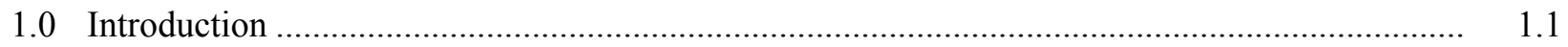

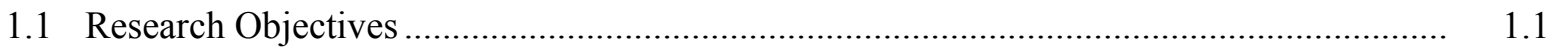

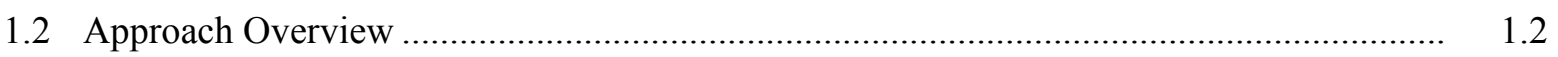

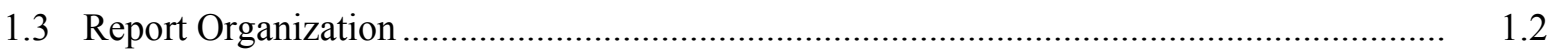

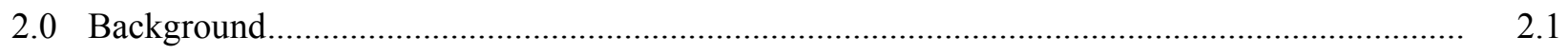

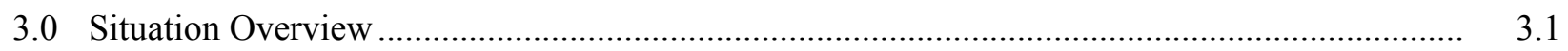

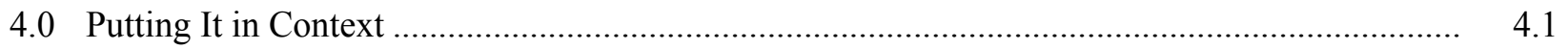

4.1 Commercial Real Estate Markets .................................................................................. 4.1

4.2 Perspective on Energy and Efficiency..................................................................... 4.2

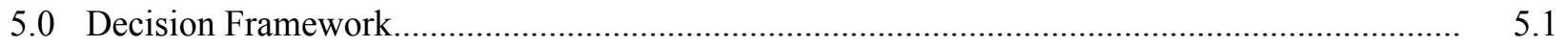

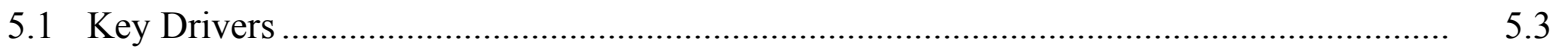

5.2 The Agency Issue or "Split Incentives" ................................................................. 5.4

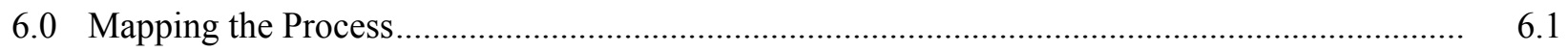

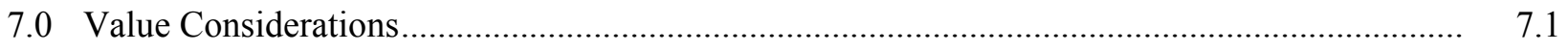

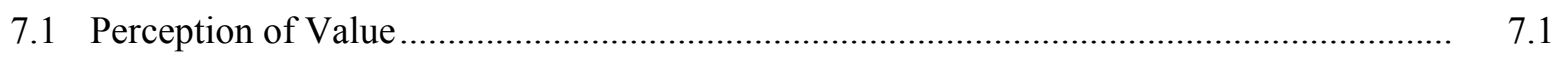

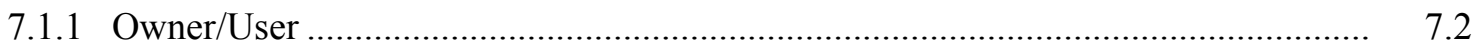

7.1.2 Investor Owner/Developer .......................................................................... 7.2

7.1.3 Portfolio Investor and Asset Manager............................................................. 7.3

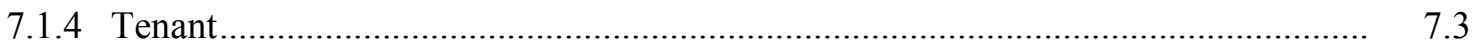

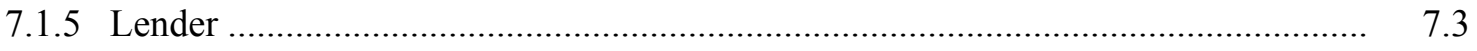

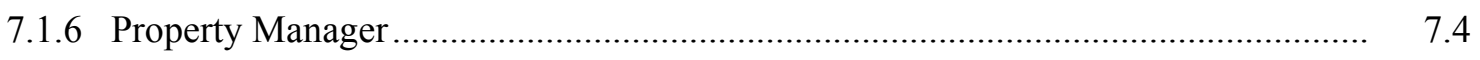

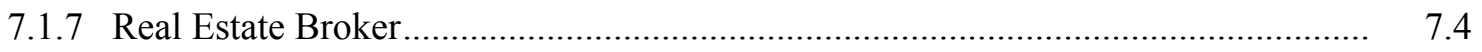

7.2 Value Analysis ................................................................................................. 7.4

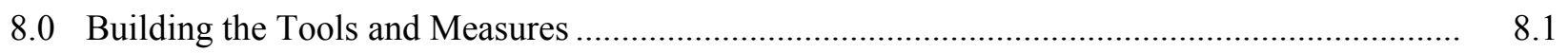

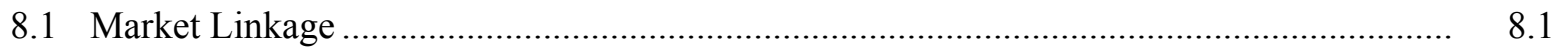

8.2 Validating Energy Efficiency ….............................................................................. 8.1

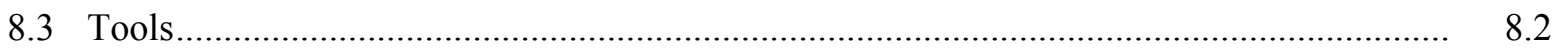

8.3.1 Industry Consensus Metrics, Third-Party Standards, and Reporting …................... 8.2

8.3.2 Access to Real-Time Numbers ............................................................................ 8.3

8.3.3 Robust Operations and Maintenance............................................................ 8.3

8.3.4 Monetizing Energy Efficiency ……................................................................. 8.3 


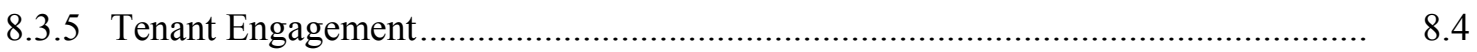

8.3.6 Public/Private Partnerships....................................................................... 8.4

8.4 Communication Strategies and Messaging …............................................................. 8.5

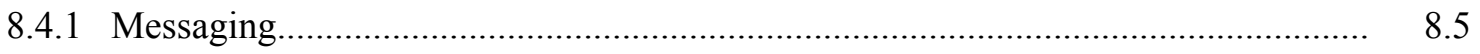

8.4.2 Communication Strategies …................................................................... 8.7

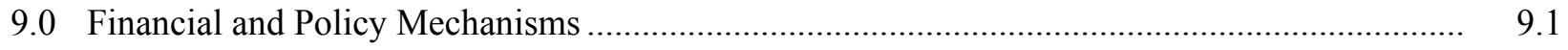

9.1 Currently Available Mechanisms ............................................................................ 9.2

9.1.1 On-Bill Pay or On-Bill Financing .................................................................. 9.2

9.1.2 Energy Services Companies ……....................................................................... 9.4

9.1.3 Power Purchase Agreements .................................................................... 9.6

9.1.4 Revolving Loan Funds ............................................................................ 9.7

9.1.5 Utility-, Federal-, and State-Based Incentives, Grants, and Rebates....................... 9.7

9.2 New and Emerging Innovative Strategies ................................................................ 9.8

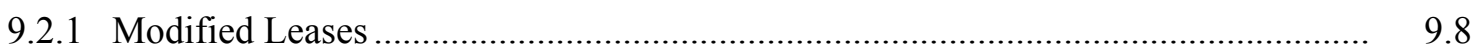

9.2.2 Energy and/or Efficiency Services Agreements and Managed Energy Services Agreements ..................................................................................... 9.9

9.2.3 Energy Efficiency Power Purchase Agreement ................................................. 9.9

9.2.4 Climate Benefit Districts/Climate Benefit Increment Financing ........................... 9.11

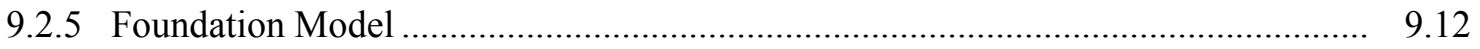

9.2.6 Green Loans/Loan Guarantees ................................................................... 9.12

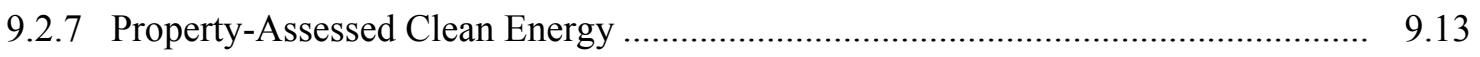

9.3 Government- and Policy-Supported Mechanisms .......................................................... 9.15

9.3.1 Utility and Government Incentives ................................................................ 9.15

9.3.2 Energy Performance Certificates and Display Energy Certificates......................... 9.17

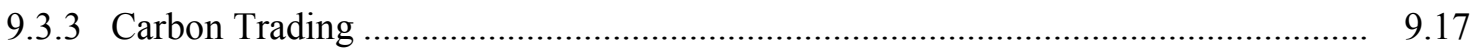

9.3.4 Efficient Building Trading Scheme............................................................... 9.19

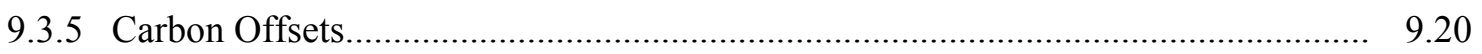

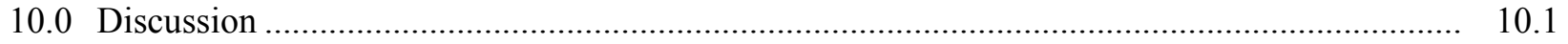

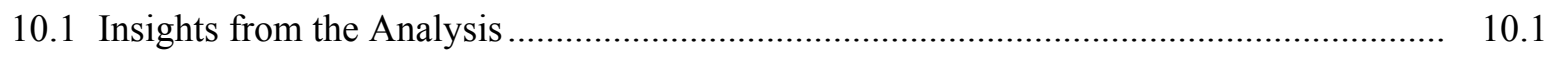

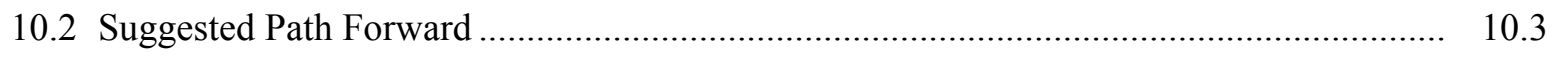

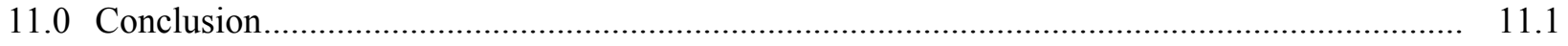

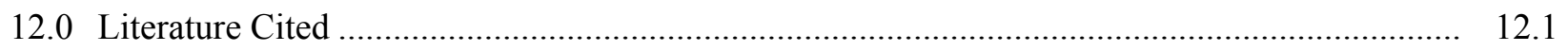

Appendix A - Commercial Buildings Integration Multi-Year Program Plan FY 2010-2015 Opportunities and Gaps Excerpt on Financing ........................................................... A. A

Appendix B - High-Performance Buildings - Literature Reviewed ............................................... B.1 


\section{Figures}

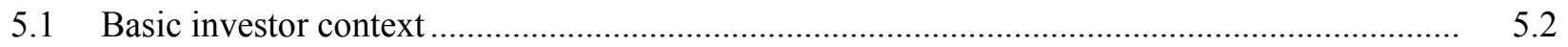

7.1 Impact of energy efficiency retrofit on net operating income, property cash flow, and

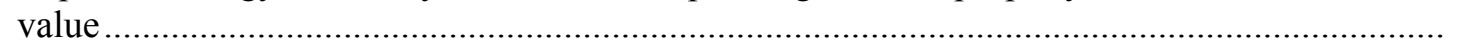

\section{Tables}

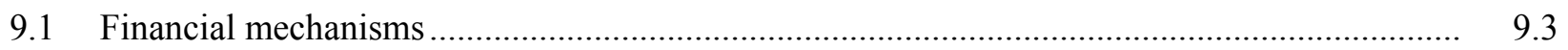

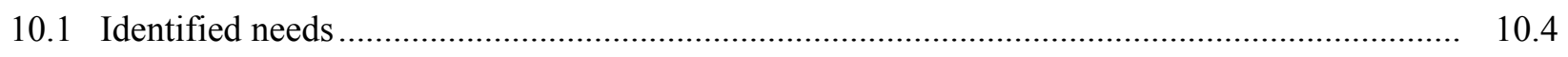




\subsection{Introduction}

The purpose of this report is to support and inform the U.S. Department of Energy (DOE) Building Technologies Program (BTP) in the area of policy and program planning for the financing of highperformance new buildings and building retrofit projects. ${ }^{1}$ The report addresses, in part, the financing analysis needs identified in the Commercial Buildings Integration Multi-Year Program Plan FY 2010-2015 (MYPP). The specific topic area was identified through the opportunities and gaps assessment completed by the Commercial Buildings Team in support of the MYPP development (see Appendix A for the full opportunities and gaps discussion on financing). This need was later prioritized in the FY10 Statement of Needs (Section 3.7, Analysis in Support of Decision-Making) as follows:

\subsubsection{Finance}

Many in the commercial building development and design communities feel that there is a significant cost premium associated with the design and construction of highperformance buildings. Further, these cost premiums are not recovered when the buildings are sold and or leased after the completion of construction. These perceptions provide a disincentive to developers to design and build high-performance buildings. DOE seeks proposals that accomplish the following:

- Work with the commercial building development and design communities to determine if there is a first cost differential for high-performance buildings.

- Explore with building developers and owners the financial mechanisms that can provide an incentive to invest in high-performance buildings.

Two specific needs are identified in the analysis description above. The identification of cost differentials is being completed as a separate effort at Pacific Northwest National Laboratory (PNNL), where a data collection protocol has been developed and data collection efforts have begun. Findings from the data collection effort will be available in FY 2011.

The second analysis need identified above is addressed in this report. Molly McCabe (HaydenTanner, LLC) was commissioned by PNNL to complete this analysis in FY 2010. Dave Hunt of PNNL is the project manager for this subcontract.

\subsection{Research Objectives}

The objectives of this analysis were 1) to evaluate the link between high-performance buildings and their market value; 2) to identify core messaging to motivate owners, investors, financiers, and others in

\footnotetext{
${ }^{1}$ The term high-performance building refers to a building that achieves significant efficiency and performance improvements in the areas of energy use, water use, indoor air quality, overall operations and maintenance, occupant satisfaction, materials waste and recovery, and occupant commute. Although energy efficiency is the primary concern of the BTP, the high-performance or "green" building community beyond DOE requires that all these operational facets be recognized and addressed.
} 
the real estate sector to appropriately value and deploy high-performance strategies and technologies across new and existing buildings; and 3) to summarize financial mechanisms that facilitate increased investment in these buildings. ${ }^{1}$

\subsection{Approach Overview}

To meet these objectives, work consisted of a literature review of relevant writings, examination of existing and emergent financial and policy mechanisms, interviews with industry stakeholders, and an evaluation of the value implications through financial modeling, as follows:

- literature review of more than 70 articles, peer-reviewed reports, and books on topics related to real estate sustainability and value; impact of financial and policy mechanisms; energy pricing and utility regulation; cost of sustainable improvements and, human behavior, social psychology, decision making, and change management

- review and analysis of existing, innovative, and emerging financial mechanisms being used or proposed nationally and internationally

- interviews with key stakeholders, including property owners, institutional and private equity investors, financiers, appraisers, property and asset managers, and senior managers from non-profit organizations, utility companies, energy service companies, equipment/product vendors, and state and federal government agencies

- evaluation of linkage between high-performance attributes and value, particularly looking at the financial and competitive impact

- external peer reviews of this report - The draft of this report was shared with four key stakeholders representing the appraisal, investor, asset manager, and real estate broker communities for input, clarification, and vetting of key data points.

\subsection{Report Organization}

Section 2 provides background on the key players in the commercial buildings sector, particularly its real estate owners and investors. In Section 3, an overview is provided of the obstacles within the industry to achieving high reductions in resource use. An assessment of the overall real estate investment decision process is provided in Section 4 to put efficiency and high-performance buildings into context. The decision framework for property investment decisions is explained in Section 5. In Section 6, the real estate investment decision process is mapped. Section 7 offers a discussion of value perceptions prevalent among the industry decision makers and provides an analysis of value. The tools and measures needed to increase investment in deep energy savings are discussed in Section 8. Section 9 focuses on existing and potential financing and policy mechanisms that will drive deployment of energy efficiency investment in the real estate sector. The findings from the overall analysis are summed up and discussed

\footnotetext{
${ }^{1}$ The statement of work for this effort, "High-Performance Building Decision Making," was separated into two tasks. This effort comprises Task 2, which addresses the market value of high-performance buildings and decisionmaking processes of building owners. Task 1, with Kim Fowler, PNNL, as the lead investigator, addresses the cost of high-performance buildings and is being completed separately. The separation between cost and value is necessary because value is driven by market factors and overall operating cash flow, while costs in this analysis are limited to design, construction, and operations and maintenance.
} 
in Section 10, which also suggests next steps for DOE, followed by a conclusion statement in Section 11. Literature cited in the text of the report is listed in Section 12. Appendix A presents the excerpt on financing from the Commercial Buildings Integration Multi-Year Program Plan FY 2010-2015 section on Opportunities and Gaps. Results of the literature survey conducted as part of this analysis are presented in Appendix B. 


\subsection{Background}

What drives the need for this work?

The perception in the commercial building sector ${ }^{1}$ is that there is a significant cost premium to achieve high-performance buildings, ${ }^{2}$ costs do not equal the benefits, and these cost premiums are not recoverable when these buildings are leased or sold. Broadly speaking, the industry judges the market risks to be greater than potential benefits or increases in value (Lutzenhiser et al. 2001).

How do we change this perspective and get building owners and investors not only engaged but excited about high-performing buildings and motivated to modify investment strategies, deploy capital, and upgrade operations and maintenance to achieve significant resource efficiency?

First, we need to define the audience. There are various categories and subcategories of commercial real estate owners and investors. Owner/users are those who use buildings to house their own employees to meet their own business needs - these may be corporate, institutional, or government entities. Then there is a broad category of real estate investors - institutional, private, core, opportunistic, large, and small. Only 5\% of commercial buildings are larger than 50,000 square feet. These large properties account for more than $50 \%$ of the total space by square footage and are generally owned by institutional investors. According to the 2003 Commercial Building Energy Consumption Survey (EIA 2006), 72\% of the total commercial buildings in the United States are 10,000 square feet or less. Overall, these figures reflect a fragmented ownership market.

Generally speaking, one of the most difficult groups to interest in deep efficiency are pure institutional investors and real estate investment trusts (REITs) who typically invest in the large square-footage properties. This category is marked by aggregated pools of funds and often disinterested owners who have allocated a portion of their investment monies to asset managers and investment advisors in the real estate sector. They are focused primarily on the real estate return compared to the return on their other investments. However, within this group is a subset of investors (e.g., TIAA-CREF, TransWestern, USAA) who do understand the benefits of high performance and efficiency and have been doing a good job maintaining and upgrading their properties. They make capital improvements when the timing is right (i.e., when equipment has reached the end of its useful life or a retrofit is necessary) and actively manage their buildings to maximize operational efficiency. These firms are forward thinking, have weathered the real estate cycles fairly well, and have positive and long-standing relationships with tenants. They often will look toward utility and government incentives and rebates to offset the costs of efficiency improvements. Then there are investors who may be interested in efficiency but who do not have ready access to capital. Either they are too small or their real estate exposure is in less desirable markets and capital availability is more limited. Finally, there are those smaller owners and investors who have never considered energy efficiency or high-performance attributes and for whom the issue is a low priority.

\footnotetext{
${ }^{1}$ Commercial property is generally segregated into five categories: office space, which can include a multistory office tower or a small suburban building; industrial, which encompasses warehouse and factory space; retail, which ranges from a small storefront in a shopping center or mall to a big-box space used by a large retailer like Costco; multifamily apartment complexes, typically with more than four units; and hotels.

${ }^{2}$ In one example, a study analyzing purchase decisions on high-performance HVAC units found "[D]istributors representing $84 \%$ of the market indicated that customers' perception of high first costs is the primary reason high efficiency units are not specified and installed more frequently" (KEMA 2006).
} 
There are other investor-related participants, such as tenants, lenders, real estate brokers, and rating agencies, all of whom have a stake in a property's performance and returns and have significant impact on the owner/investor's decision.

If the goal is to engage property owners in a way that motivates them to invest in the construction and retrofit of high-performance buildings, the message needs to be centered on the financial impact to the property and/or portfolio, focused on risk and return. High-performing buildings are a hedge against future risks such as competitive obsolescence, energy price volatility, resource availability, and pending regulatory changes. ${ }^{1}$ And, for some, there is an increasing recognition of a link between higherperforming buildings and health of occupants and the corresponding impact on risk/return and value. Ultimately, there is a need to assist property owners, investors, and lenders in evaluating the true risks associated with a given property in concert with the opportunities for return. Overall, high-performing properties save money-money that will increase net operating income and consequently the value of the property.

\footnotetext{
${ }^{1}$ There are no disclosure mandates yet, but in some markets such as New York, San Francisco, and Seattle, disclosure of energy consumption is right around the corner.
} 


\subsection{Situation Overview}

Studies such as those conducted by the World Business Council for Sustainable Development (WBCSD) and McKinsey \& Company ${ }^{1}$ show that vast reductions in resource use are possible, even in the face of an increasing absolute number of buildings (WBCSD 2009; Granade et al. 2009). However, clearly this is not happening on a wide-scale basis. Why are we not deploying that which we know we have the technology to accomplish and that makes sense to deploy? The obstacles to achieving this level of performance and efficiency in the building sector take many forms, many of which derive directly from the investment side of the equation:

- first costs and short-term investment horizons

- inadequate awareness of and interest in efficiency including risks associated with the impact of future regulation and energy prices

- low priority of energy issues as compared to other factors (such as tenancy, rental income, short term return on investment, competing capital needs)

- difficulty in "seeing" actual energy usage or its costs in real time

- practical limitations on obtaining a complete picture of energy consumption for the entire building (i.e., lack of submetering, lack of access to tenant data, "ownership" of energy consumption data)

- cultural inertia driven by standard practices in design, construction, and operation that enable inefficient energy use and equipment applications over the building life

- financial transaction costs that create agency issues, inherent conflicts between stakeholders; for example,

- utility incentives that reward kilowatt-hours used instead of kilowatt-hours saved

- financial structures and investment horizons that typically do not go beyond 3 to 5 years and consequently do not accommodate the longer-term payback ( $>3$ years and frequently much longer) often needed to reach deep efficiency ${ }^{2}$

- principal-agent problems (the split-incentive), such as a difference between who pays for the investment and who benefits from the performance

\footnotetext{
${ }^{1}$ The WBCSD is a CEO-led global association of some 200 companies dealing exclusively with business and sustainable development. Its Energy Efficiency in Buildings Project was led by a core group of 14 corporations and co-chaired by United Technologies and Lafarge. McKinsey \& Company is a global management consulting and research firm.

${ }^{2}$ In reality, this may not be as substantial a hurdle as it appears on the surface. The issue really drives toward the nature and depth of the improvements. Amory Lovins has posited that when you reach significant efficiency, you "tunnel through the cost barrier," whereby "when designed as whole systems, the superefficient [building] can often cost less than the original, unimproved version" (Hawken et al. 2008, p. 114). Among others, property owners along with researchers at the New Buildings Institute have confirmed that their research and pilot projects support this conclusion. However, this presumes a holistic and whole-building approach and creative architects and engineers, incorporating tenant engagement - not typical of today's construction or retrofit process. One of the key challenges in reaching this point is a limited design budget that incentivizes design professionals to use existing plans as the basis for new and retrofit projects, consequently limiting overall cost and a risk factor resulting from new modes of design (one engineer mentioned that the cost of his liability insurance increases if the design is not the tried and true standard). One way to enhance deep efficiency design could be by providing technical assistance to the design team.
} 
- who pays the costs of getting people up the learning curve - upfront training and education

- societal benefits that do not translate into individual owner benefits

- operational and budgetary fragmentation that divides the analysis and decision making regarding capital investments from operating costs

- shortage of skilled service providers

- regional differences that require capacity building among building professionals

- the imprecision of energy modeling as a tool - Actual results often do not meet the modeled results, leading to skepticism about efficiency outcomes.

- inadequate persistence and performance of efficiency measures

- limited historical, comprehensive, and reliable financial data on investment returns for highperformance components.

In 2007, the Swedish utility company Vattenfall AB and the consulting firm McKinsey published a very influential study comparing the greenhouse gas abatement potentials of various strategies and technologies to their respective costs, including those in the transportation, industrial, and building sectors. In January 2009, McKinsey updated this widely circulated and heavily discussed analysis (McKinsey \& Co. 2009). The analysis

\section{The Energy Efficiency in Buildings project of the World Business Council for Sustainable Development (www.wbcsd.org) has found that low-cost opportunities are likely to achieve only limited reductions in energy and $\mathrm{CO}_{2}$ emissions. To achieve deep energy savings, improvements must go beyond fast payback measures such as lighting, appliances, and leak sealing. They frequently include upgraded windows, attic and wall insulation, new ductwork, and HVAC system overhaul.}

Basic weatherizing and lighting may save $5 \%$ to $15 \%$ of energy use. More extensive retrofits can save $20 \%$ to $50 \%$ or more. Due to the nature of the deep efficiency upgrades, they often have a longer lifespan. Accordingly, these modifications frequently have long payback periods that are not financed easily with conventional means and may require incentives, extended loan terms (10 to 20 years), or alternative types of financing that tie directly to the property rather than to the owner. evaluates the potential magnitude of savings in carbon dioxide $\left(\mathrm{CO}_{2}\right)$ emissions versus cost of each abatement measure. Many of the positively correlated strategies include a variety of "cost-effective" building-related changes - lighting, insulation, and retrofitted HVAC systems. The report implies that future energy savings could potentially pay for the upfront costs.

However, as the authors point out, it is one thing to have significant potential and another thing entirely to implement the necessary changes. Massive behavior modification and major capital resources are required. Further, the benefits and the cost of abatement are calculated from a societal perspective rather than from an individual investor point of view. Few property owners will invest their hard-earned dollars on a philanthropic basis simply for the public good, highlighting some of the challenges inherent in making broad assumptions on the ease of implementing the technology available today. Moreover, every building is unique, and the solutions both available and appropriate will differ widely. As a building owner, it would be difficult to use McKinsey's data to make investment option decisions on an individual level. Hence, it is necessary to develop a full range of tools that can be deployed in concert to maximize performance for any given building. 
Integrated solutions start with a whole-building (or even district-wide) approach that incorporates advanced technology, ongoing commissioning, education, and training (operations staff and occupants), along with universally agreed-upon benchmarks, measurement standards, and mandated improvements in efficiency. When supported by financial incentives, modified lease structures, and cost/benefit-sharing that align stakeholder interests, these integrated solutions result in more rapid deployment of measures and in meaningful and persistent performance, thereby facilitating investment decisions. No single lever alone can rapidly drive meaningful change. 


\subsection{Putting It in Context}

Based on the available technology, information, and media attention on energy, greenness, and sustainability, it would be reasonable to expect widespread interest and adoption of high-performance attributes. Actual investment in high-performance buildings is sluggish. The question is why. The answer lies in putting efficiency and high performance into context as part of the overall real estate investment decision process.

\subsection{Commercial Real Estate Markets}

The commercial real estate markets are currently hampered by the lack of available external capital and the overarching economic downturn, which impacts owners directly and indirectly though inability to finance projects, tenant downsizing (and bankruptcy), reduced travel and discretionary spending, and budgetary restrictions. According to real estate research firm Reis Inc., the commercial office market had a national vacancy rate of $17.4 \%$ as of the end of the second quarter of 2010, the highest since 1993 (Troianovski 2010). Further, the situation is particularly acute for the hundreds of office properties in uncertain financial condition because they are worth less than the mortgages that were made prior to 2008. Owners need to fill space to increase rental revenue - and values. Consequently, most investor commercial property owners are conserving cash to deal with tenant rollover and debt repayment rather than putting money into large retrofit projects.

Current sentiment is that while the economic recovery is proceeding, the upturn (and in commercial real estate in particular) will continue to be muted over the next few years. In its June 2010 meeting, the Federal Reserve System Federal Open Market Committee (FOMC) projected the economy will grow at a real rate of $3.0 \%$ to $3.5 \%$ in $2010,3.5 \%$ to $4.2 \%$ in 2011 , and $3.5 \%$ to $4.5 \%$ in 2012 , with a long-run projection of growth at $2.5 \%$ to $2.8 \%$ (FOMC 2010a). The FOMC meeting on August 10, 2010, confirmed that pace of recovery has continued to slow in recent months (FOMC 2010b).

In minutes from the June meeting (FOMC 2010a), the FOMC cited specific concerns about the health of commercial real estate markets, writing

The outlook in commercial real estate markets stayed weak; prices of commercial properties fell a bit further in the first quarter, and the volume of commercial property sales remained light. The delinquency rate for securitized commercial mortgages continued to climb in May....

Real estate values have become unmoored from property performance. And, even high-performance buildings able to show superior returns are not immune to the value declines. On a more positive note, the FOMC did cite anecdotal evidence of improved credit availability for good credit quality borrowers (FOMC 2010a):

Participants also noted ongoing difficulties in financing commercial real estate. Nonetheless, reports suggested that more-creditworthy business borrowers were still able to obtain funding in the open markets on fairly attractive terms, and a couple of participants noted that credit from the banking sector, which had been contracting for some time, was showing some tentative signs of stabilizing. 
Overall, however, the deterioration in commercial real estate lending portfolios remains a factor for the stability of banking (FOMC 2010a):

... despite improvements in the condition of banking institutions, strains in the commercial real estate sector were seen as posing risks to the balance sheets of such institutions for some time ... Participants noted that problems in the commercial real estate market and the effects of financial regulatory reform could lead to greater constraints on credit availability, thereby restraining growth of output and employment.

In spite of these current constraints on the capital markets, new financial structures are being piloted that will facilitate investment in high-performance buildings, financially strong owners can receive loan dollars (even if loan amounts are steeply curtailed), and solid properties are trading hands at acceptable investment returns.

\subsection{Perspective on Energy and Efficiency}

Results of a global survey released in June 2010 (Johnson Controls 2010b) note that a majority of senior-level executives at responding companies (71\%) are paying more attention to energy efficiency compared to 12 months ago. ${ }^{1}$ The key driver both in the United States and globally is the potential for energy cost savings. Of the North American respondents to the survey, 64\% indicated believing that prices for energy will rise over the next 12 months, with an average expected increase of $7 \%$. In comparison, the U.S. Energy Information Administration (EIA) Annual Energy Outlook for 2010 reflects declining to stabilized prices for the next 10 years. $^{2}$

What is relevant here is that investors make a decision to invest based on a number of things, including their own perception of energy prices rather than a differing conclusion reached by energy experts such as the EIA. At the same time investors look to the future and perceive increasing energy costs, they also are evaluating the cost of the efficiency measures compared to the efficiency generated and how long it will take to see a return on their investment. In looking at efficiency investments, $44 \%$ of the North American respondents in the Johnson Controls study would require a simple payback of less than 3 years (not dissimilar to other retrofit investment decisions). It is important to note that these senior-level respondents are evaluating the perceived opportunity in the context of competing needs for

\footnotetext{
${ }^{1}$ For the fourth consecutive year, Johnson Controls, International Facility Management Association (IFMA), and the American Society for Healthcare Engineering (ASHE) conducted the North America Energy Efficiency Indicator (EEI) survey of 1,435 decision makers responsible for managing energy use within commercial buildings across North America. The March 2010 EEI survey examined the attitudes, practices, investment plans, and expected return-on-investment for energy management initiatives among decision makers in commercial buildings. The majority - $58 \%$ of the respondents - is characterized as vice president level or above, $25 \%$ were facility managers, and $10 \%$ were direct owners. The study targeted primarily large property owners $-73 \%$ of respondents had responsibility for properties totaling greater than 100,000 square feet. Sectors included healthcare $(20 \%)$, consulting/legal services (9\%), manufacturing (7\%), financial services (7\%), government $(6 \%)$, and retail trade $(5 \%)$ sectors; $90 \%$ were from the private sector, and $10 \%$ were from the public sector. More than $60 \%$ spend at least $\$ 100,000$ per year in energy costs to power their facilities (Johnson Controls 2010b).

2 "Real average delivered electricity prices in the $A E O 2010$ reference case fall sharply from 9.8 cents per kilowatthour in 2008 to 8.6 cents per kilowatt-hour in 2011 and remain below 9.0 cents per kilowatt-hour through 2020" (EIA 2009, p. 4, col. 1). "Throughout the projection, electricity prices are linked to natural gas prices. Once natural gas prices begin to rise steadily, electricity prices also begin to increase, reaching an average of 10.2 cents per kilowatt-hour in 2035" (EIA 2009, p. 4, col. 2).
} 
capital, returns on investment, and available funds. Further, although the study indicates an increasing level of consciousness (which likely results from increased attention and publicity around the Energy Star and LEED programs ${ }^{1}$ ), it does not reflect a concrete commitment to actual investment in, or implementation of, efficiency or high-performance measures.

Although there may be a growing interest in energy efficiency improvements and sustainability, action still lags talk. ${ }^{2}$ With the exception of a few high-profile projects such as the Empire State Building sustainability retrofit, ${ }^{3}$ some earlier adopters, and government-initiated projects, widespread action has not been taken on increasing deep energy efficiency in buildings. Amongst the Johnson Controls survey respondents, the greatest barrier continues to be capital availability (noted by $38 \%$ in North America and $29 \%$ globally), followed by insufficient payback (21\% in North America and $18 \%$ globally,) and uncertain savings (16\% in North America and 18\% globally) (Johnson Controls 2010a, 2010b).

\footnotetext{
${ }^{1}$ The U.S. Environmental Protection Agency (EPA) Energy Star building rating program and the U.S. Green Building Council Leadership in Energy and Environmental Design (LEED) certification.

${ }^{2}$ The literature review conducted as part of this task (Appendix B) indicates a growing number of research papers and publications on sustainability and energy efficiency. These provide a glimpse into successes by early adopters but do not reflect a groundswell of statistically meaningful activity.

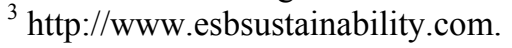




\subsection{Decision Framework}

The decision framework for any property investment decision can be divided into three types of decisions: strategic, tactical, and property-specific (Muldavin 2010, p. 80, Exhibit IV-5). ${ }^{1}$

Strategic decisions are broader in context; for example, how will we respond to the issue of sustainability generally, and specifically within our own portfolio? These decisions are typically made at the CEO or board level. Statistical modeling, research, and other market-based analysis that looks to the value of sustainability at an enterprise level are used in making this type of decision. From the perspective of sustainability and high-performance characteristics, the key questions at this point are

Should we invest in sustainable buildings? ${ }^{2}$

Should we evaluate our existing property or portfolio of properties in the context of sustainability?

Tactical decisions take the strategic determination to invest in sustainable properties to the next level. How should we go about investing in sustainable properties? The decision-making process is passed along to asset managers and others who are tasked with determining how to best execute on the strategic decision to invest. At this level, decisions are made on the basis of portfolio strategies and sustainability options. The key questions here are

Which property types and with which attributes? $?^{3}$

How will we evaluate our existing investments in the context of sustainability?

On what basis will we make a decision to retrofit or dispose (sell) a property?

Then the decision must be made as to which property to invest and which property to sell. Propertyspecific decisions are focused explicitly on individual properties. These decisions are made "on-theground" by those responsible for analyzing different investment choices and making reasoned recommendations. The decisions require in-depth analysis on the opportunities, risks, and benefits for a specific real estate asset. The key questions that surround the investment decision at this point include

What are the risks and returns for specific investments for a given property?

How will the sustainability features impact the property value and its competitive positioning in the marketplace?

For any given real estate owner, the decision to invest in high-performance measures is predicated on their individual risk/return perspective, worldview, and their own long-term objectives and corporate values, as reflected in Figure 5.1.

\footnotetext{
${ }^{1} \mathrm{http}: / / \mathrm{www}$.greenbuildingfc.com.

${ }^{2}$ Ibid.

${ }^{3}$ Ibid.
} 


\section{Investor Type}
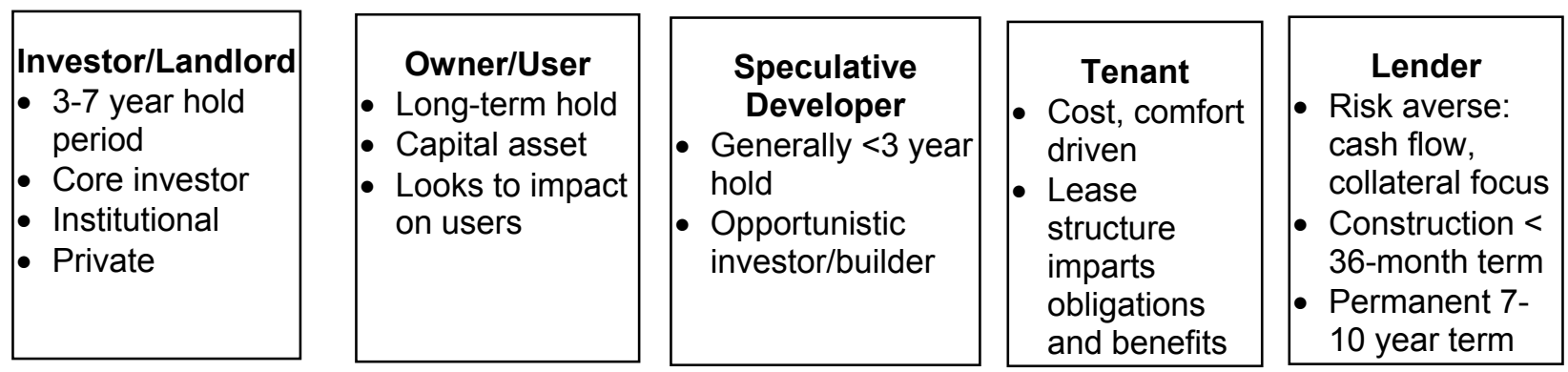

Figure 5.1. Basic investor context

For example, owners/users who tend to have longer-term hold mindsets are generally more likely to invest in technologies that require a longer payback period because they are able to wait longer to recoup their investment and tend to reap the rewards of efficiency for a longer period. Institutional and other mainstream real estate investors will prioritize competing capital needs on the basis of necessity, returns, and the potential to improve leasing, use, or competitive position in the market. For example, will improvement ensure the property maintains its status as a Class A space with correspondingly higher rents? Again, depending on the nature of the investor, these owners may take a long- or a short-term view of their investments. Properties that by the nature of their lease structures, which allocate capital costs to owners and operating benefits to tenants/occupants, will likely require new contractual agreements, financial structures, or both. Further, owners of leased property as well as real estate brokers often make money from utility charges passed along to tenants. Reduced utility costs due to resource efficiency could reduce revenue for both, leading to a disincentive to invest or to push for higher efficiency.

\section{Decision-Making Factors for Existing Building Retrofit}

- Worker/tenant displacement during retrofit

- Impact on revenue stream

- Upfront cost and return time horizon (including property hold period)

- Deep energy efficiency retrofit timing often predicated on whole building (or substantive) renovation

- Timing of tenant turnover

- Investments prioritized on the basis of impact on property value and cash flow (i.e., is it necessary to keep tenants, will it increase tenant interest or rental revenue, will it impact operating costs over the long term?)

- Will the retrofit ensure competitiveness, or can it result in up-tiering or repositioning in the marketplace? 


\subsection{Key Drivers}

Typically, high-performance and energy efficiency improvements are done in conjunction with a major retrofit - driven largely by the age of the property and its improvements but also driven by a desire to avoid competitive obsolescence as other more efficient buildings come on line. Capital projects are budgeted in advance and prioritized on the basis of necessity, enhanced lease desirability, and anticipated returns.

Different owner strata have differing motivations. Owner/users evaluate the investment in the context of competing needs for capital along with a desire to meet certain corporate objectives (e.g., expense reduction, corporate social responsibility $(\mathrm{CSR})^{1}$ goals, corporate values, public image). Private sector investors have, in the past, looked to a short-term bump in net operating income that they can parlay into a higher sale value in the near term. In comparison, energy efficiency measures are generally seen as investments with longer-term returns. Most private sector investors look to hold properties for 3 to 5 years; 7 years is rare and would be considered a long-term hold. To meaningfully accrue value to the building upon sale, efficiency performance must be measurable, verifiable, and persistent over the life of the improvements.

The inflection point that will enable efficiency to scale beyond the earlier adopters in the private sector is the intersection of tenants defining high performance as industry best practice and an owner who believes they will receive enhanced leasing interest if they have a resource-efficient building. This point is further defined when owners recognize there is inherent risk due to the potential for competitive obsolescence, energy and resource price volatility, and pending regulation.

For private sector investors, the following components are relevant in the decision to act:

- financing that requires minimal or no initial capital outlay

- improvements that result in positive impact on cash flow net operating income (NOI) from reduced operating expenses due to energy savings

- opportunity to benefit from government and utility incentives and depreciation treatment

- measurement and verification $(\mathrm{M} \& \mathrm{~V})$ of efficiency over a baseline (which strengthens the case for investors, lenders, and tenants)

- ongoing commissioning (monitoring and tuning) and a robust operations and maintenance (O\&M) program, which ensures systems are operating at peak performance and may result in more satisfied occupants

- future proofing against energy price and regulatory risk and avoided competitive obsolescence

- higher Energy Star or LEED rating that, particularly in combination with strong M\&V and robust O\&M, may result in higher property valuation

- potential to increase net rentable area as a result of smaller, more efficient systems.

Some of these factors are similar for a second set of property owners who can be characterized as owner/users - essentially the corporate market or municipal, state, and federal government entities — but

\footnotetext{
${ }^{1}$ Corporate social responsibility goals also may be referred to as environmental, social, and governance.
} 
some are vastly different. These owners generally are long-term holders of property where real estate ownership is not their primary business. They control real estate as a means to conducting business or governing. They manage the movement of their own occupants/workers in and out of space. They are interested in occupant comfort and health because this meets their corporate values and believe it translates into enhanced worker satisfaction, retention and recruitment, and possibly productivity. Although they might get their buildings Energy Star or LEED rated, they do it more because it correlates with their fundamental values or for public relations purposes rather than with any residual value driver. In the current economic environment, these entities may also be capital constrained and want to retain cash for operational purposes and may look for outside financing for efficiency improvements. They are interested also in increasing cash flow, which allows them to invest more in their core business. This segment of the commercial owner market is more likely to engage immediately in an efficiency project due to their long-term hold horizon, the direct benefits derived by their workers, and the corresponding impact on cash flow.

\subsection{The Agency Issue or "Split Incentives"}

The fundamental nature of the real estate industry skews the distribution of benefits among the various stakeholders, which can be called the "agency issue." Unfortunately, the various stakeholders do not always perceive or capture the immediate benefits of sustainable or energy-efficient design. There are two agency issues at hand - the first is the different accruals of benefits. For example, if tenants are responsible for a building's electric bill, then the building's owners may not see the advantage in installing energy-saving heating, ventilating, and air conditioning (HVAC) or lighting systems. It is hard for anyone to rationalize an additional expense, especially when we do not believe we will enjoy an immediate return on our investment. The second agency issue is differing perspectives of the agents on the actual value of the interventions; for example, societal benefits that do not translate into individual owner benefits, such as upfront training costs to get people up the curve.

By the nature of their tolerance for risk as compared to return, most financial structures and investment horizons typically do not go beyond 3 to 5 years and consequently do not accommodate the longer-term payback ( $>3$ years and frequently much longer) often needed to reach deep efficiency levels.

The same concept applies to utility companies. As power providers, they are usually compensated on a straight kilowatt-hour basis for energy used. Unless they are obligated to reduce demand, or unless they are also compensated or rewarded for lower consumption levels, they have little incentive to promote efficiency.

In addition to this lack of vertical integration, we are generally short on benchmarks and feedback mechanisms for the designers and builders. Without these tools, it is difficult to hold designers and builders accountable for ongoing building performance. And when we cannot measure overall building performance or hold people accountable, the entire design/construction process is likely to be driven by short-term economic considerations and local building codes. 


\section{Energy Prices and Utilities}

Energy prices and utility policies impact investment in high-performance properties in several important ways. These include accurate projection of energy costs and potential savings, cash flow projections, value and risk assessment.

Savings anticipated from efficiency investments are calculated on the basis of the quantity of energy saved multiplied by the price of energy. Absolute energy prices determine future operating expenses and thereby impact projections for net operating income $(\mathrm{NOI})$ and consequently value. Risk associated with energy price volatility can be mitigated by efficiency improvements. The perception of reduced or increased risk will be captured in the capitalization and discount rates when valuing property. (Higher perceived risk results in higher capitalization and discount rates, which results in a lower valuation.) Further, regional differences in energy prices impact the benefits derived from energy efficiency. In regions where energy prices are high, such as in the Northeast, Hawaii, and California, efficiency measures will be easier to justify because the savings are that much greater.

The Brookings Institution identified barriers and key opportunities that would engender change in the utility markets and level the playing field between energy efficiency and generation sources to meet demand (Risser and Wood 2009). Some key points:

- Treat energy efficiency as an investment, with mechanisms to deal with the recovery of lost revenue (i.e., decoupling) and performance incentives (such as shared benefit and/or higher returns on efficiency).

- Allowing utilities to recover lost revenues to cover fixed costs is critical. Without it, utilities have little incentive to invest significantly in energy efficiency.

- Efficiency investments must be able to earn a "return" equivalent to other capital investments.

- Regulated utilities recoup fixed costs based on energy sales. If sales fall below a certain level, then utility cannot recover sufficient revenues to cover fixed costs (which include "profit" or margin). Solutions offered:

- Allow all or a portion of investment in efficiency to become part of rate base( i.e., capitalized and depreciated).

- Increase the utility's rate of return for efficiency investments through a higher incentive, such that lower sales of energy will be offset by the higher return.

- Provide financial incentives for achieving specific energy savings targets and penalty for not meeting targets.

- Use the following approaches to manage lost margin recovery:

- Provide for adjustment mechanisms that address lost revenue (i.e., recover lost revenue by increasing rates)

- Decouple revenues from sales.

The solution has broad appeal: Customers who install efficiency measure will immediately see reduced monthly bills. Over time, even those who do not install efficiency measures may see benefits as overall system demands decline and overall rates decline.

Compared to future options to generate new power, energy efficiency is far less expensive.

To effectively scale, there is a need to deploy

- advanced metering infrastructure with two-way communication between utility and customer

- distributed resources to the grid

- regulatory policies that align the customer, utility, and investor interest around efficiency.

Drawn from Risser and Wood (2009), which addresses the impact of the regulations impacting utilities and the ease of deploying efficiency measures more broadly. 


\subsection{Mapping the Process}

When we take a moment to consider a typical building project from its inception through occupancy and operation, we see a succession of discrete although interrelated and interdependent, perspectives and roles. Real estate investment decisions are multi-faceted and complex. Different owner strata have differing motivations. Decisions involve numerous stakeholders with both competing and complementary objectives. For real estate investors, owners, and financiers, investment analysis and decision-making are led by traditional bottom-line factors such as revenue, expenses, risk, and return, rather than by the narrower life-cycle cost analysis. And each participant views these factors through their own lens.

- Owner-users, along with institutional and public building operators, bring their own complex set of multi-dimensional lenses. They are concerned about upfront costs and ongoing operations, but they are focused also on branding and image, CSR goals, employee retention, health, productivity, and recruiting.

- Even in sustainably minded corporations, managers from different departments face competing incentives. The group or department who will use a specific space frequently works with the architect to design the space and pays for the new facility out of its capital budget. After moving in, operating expenses are often covered through another corporate group such as Corporate Real Estate or Facilities.

- With an investment property, the owner, developer, and investment manager are concerned with maximizing total return over a limited time period, which often means minimizing up-front costs. Further, these time periods may not correspond.

- Architects often bid on fixed-price contracts. Consequently, they may have little incentive to include sustainable or energy efficiency features that are not required by local building codes (unless required in their contract).

- Contractors without special incentives or requirements try to minimize their upfront costs-generally installing the least-expensive equipment that meets specifications. Building codes, permits, and the availability and cost of materials and skilled subcontractors are their primary concerns.

- The construction project manager is focused on completing construction on time and on budget.

- The leasing agent is paid on commission based on the lease rate (often including utility charge reimbursements). Brokers are a key link in the sustainability chain. As can be seen by the Grubb \& Ellis Company's involvement in the DOE Global Superior Energy Performance Partnership, ${ }^{1}$ an increasing number of brokerage firms are targeting sustainability as a differentiator for their agents, and some incorporate training into their overall operations.

- The property manager is concerned with getting the property up and running, which implies that extended downtime or new maintenance protocols can impact the ability to run the building at a profit. Furthermore, typical compensation structures involve commissions based on total rent. (These commissions often incorporate tenant utility reimbursements, which can discourage energy-saving activities).

\footnotetext{
${ }^{1} \mathrm{http}: / /$ energy.gov/news/documents/GSEP-Fact-Sheet.pdf.
} 
- Potential tenants look for the best rent, floor plate layout, and location. Despite the increasing number of large corporate tenants looking for "green space," most move in after the building is complete, with little understanding of sustainable or green features.

- There is little doubt that the growing number of tenants looking for this type of space will drive the market. Increasingly, requests for proposals by tenants seeking space are incorporating a requirement for high-performance (Energy Star or LEED) buildings.

- Management and operational issues impact existing tenants around things related to comfortlighting, airflow, and temperature, as well as space and energy usage (duration and time of use) whose solutions may not align with high-performance standards. Leases generally incorporate specific comfort standards such as temperature ranges, lighting, and HVAC system operation.

- Lenders, mortgage investors, and insurers try to reduce risk. Complexity and unfamiliarity with highperformance systems imposes a level of uncertainty in their underwriting analysis, which by its nature connotes greater risk.

- Appraisers currently have no standardized tools with which to incorporate sustainability into their evaluation. At a minimum, they evaluate sustainable buildings by comparing them to similar conventionally built properties. Because there is a lack of compiled data, appraisers have no easy way to integrate and validate sustainability results. Without the proper data or education, they are unlikely to give credit in the form of a lower rate or higher loan-to-value (LTV) ratio. They may even consider the features an added risk. 


\subsection{Value Considerations}

It is not just first costs or even a simple payback analysis that drives investment decisions. In fact, the process encompasses a complex set of variables, unique to each type of stakeholder and each decision maker individually. Broadly speaking, the industry does judge the market risks associated with highperformance attributes to be greater than potential benefits. In part, this is based in reality-products are unproven, skilled service providers are few and far between, and definitive data are unavailable. Many property owners believe they know how to manage their buildings, and they manage them efficiently. Even though they constitute a large component of operating expenses, utility costs do not impact value nearly as much as rent and occupancy. Ultimately, to overcome the barriers that limit investment in highperformance attributes, real estate professionals must look at the entire value picture including risks and benefits associated with high-performance standards.

The obvious question arises: what is a meaningful level of efficiency that will cause investors to stand up and take notice because they see an obvious impact on value? So many factors go into a valuation, there is never a point where "everything is equal" and apples can be compared to apples. When differences in use, occupancy, location, and construction are incorporated, the analysis for each property becomes complex and unique to that asset and investor. Having said that, $10 \%$ efficiency gain is insufficient - there is too much room for volatility, and the absolute financial impact is not compelling enough. At $20 \%$ savings, investors will take notice, but they need to be convinced the efficiency and savings are durable. What will carry the weight along with the absolute percentage reduction is the meaningful tracking and management due diligence to ensure persistence of results. This requires accurate measurement and verification, real-time monitoring, and a proactive operations and maintenance protocol. Ultimately, this allows the performance to be incorporated into the valuation of the property.

Two recent studies (Pivo and Fisher 2009; Kok et al. 2009) have shown a correlation between Energy Star ratings and increased rent and value. Both studies indicate that the broader sustainability index, LEED, is a more difficult nut to crack in terms of clear value indicators. However, for properties with high Energy Star ratings, they have found a 5.9\% increase in net income (due primarily to lower utility costs, although not exclusively) and higher rents and up to a $16 \%$ higher return on ultimate sale. Generally speaking, there is an argument to be made that a higher-performing building equates to higher quality overall. This is supported by a strong M\&V of performance and energy savings and ongoing commissioning as well as a robust O\&M process. And tenants, especially large corporate and government ones, recognize this and have begun to use high-performance measures as a litmus test. Further, as investors look to reposition an asset through deep efficiency retrofits (either to maintain their position as a Class A property or up-tier from one below), the improvements and active ongoing maintenance and commissioning signal the market that this building is best in class.

\subsection{Perception of Value}

Value considerations are important in framing the message. Broadly speaking, the industry judges the market risks associated with high-performance attributes to be greater than potential benefits. This judgment is based partly in reality and partly on cultural barriers, business norms, and competing stakeholder interests. The perception of value depends on the stakeholders, investment objectives, access to and cost of capital, property type, and lease structure. 
Different stakeholders accrue different benefits. Increased NOI and risk reduction create value for investors, while lower operating expenses, higher worker retention, increased satisfaction (which may equate to productivity), and enhanced branding and image are major advantages for occupants. There is no "one size fits all" answer. Stakeholders evaluate the property through their own unique lens. Ideally, that includes understanding the needs and interests of everyone else involved in the process. However, as in any transaction, that is not always the case.

If the goal is to align everyone's interests, then we must utilize new contracts that focus on accountability and shared benefits at the same time we create standardized performance metrics that define and measure success. To be successful, solutions and messaging must directly address value and bottom-line results.

The following paragraphs consider the perceived benefits of sustainability for different stakeholders.

\subsubsection{Owner/User}

- lower operating expenses

- monetization of incentives - grants, tax credits, tax abatement, fast tracking, accelerated depreciation

- monetization of excess electrical capacity through net metering and/or sale back to utility

- hedge against utility (electricity, gas, water) price volatility and resource availability

- enhanced reputation and branding: public relations from "first mover" advantage and market differentiation as "thought leader":

- improved community relations

- improved client relations and market opportunity

- improved employee satisfaction and loyalty

- stronger recruiting capability

- potential for increased employee satisfaction (which may lead to enhanced productivity) and health

- for publicly traded companies, a guard against shareholder initiatives that could force sustainability initiatives, which may or may not be appropriate or desired

- long-term-increased market value of property.

\subsubsection{Investor Owner/Developer}

- net revenue enhancement through lower operating expenses and potentially higher rents (increased demand and limited supply)

- potential for quicker lease-up (absorption) higher occupancy and tenant retention

- potential for increased market value due to higher NOI and lower risk exposure as reflected in reduced cap and discount rates and higher Energy Star or LEED ratings

- enhanced reputation and branding: public relations (PR) benefit from "first mover" advantage, market differentiation as "thought leader," and limited competition from other sustainable properties 
- monetization of incentives: grants, tax credits, tax abatement, fast tracking, improved floor-area ratio, accelerated depreciation

- hedge against utility price volatility (e.g., electricity, gas, water) and resource depletion

- hedge against competitive (or economic) obsolescence.

\subsubsection{Portfolio Investor and Asset Manager}

- superior portfolio returns ${ }^{1}$

- reduced exposure to utility price volatility and resource depletion

- monetization of incentives: grants, tax credits, tax abatement, fast tracking, accelerated depreciation

- monetization of excess electricity capacity through net metering and/or sale back to utility

- monetization of portfolio-wide improvements through buying power associated with scale

- hedge against future regulation (e.g., global warming/ carbon, building code, minimum energy requirements)

- widening of potential pool of socially responsible investors and responsible property investors who are reporting and publicizing their corporate social responsibility activities (e.g., Carbon Disclosure Project, Principles for Responsible Investment)

- hedge against competitive obsolescence

- increased market value of property.

\subsubsection{Tenant}

- lower operating expenses

- hedge against utility (electricity, gas, water) price volatility and resource availability

- enhanced reputation and branding: PR from "first mover" advantage and market differentiation as "thought leader"

- improved client relations and market opportunity

- improved employee satisfaction and loyalty

- stronger recruiting capability

- potential for increased employee productivity and health.

\subsubsection{Lender}

- reduced risk due to the owners' and/or tenants' lower exposure to energy price volatility and resource availability, reduced lease-up time, greater tenant retention, and increased property value

\footnotetext{
${ }^{1}$ Innovest's analysis of 30 of the largest North American REITs by market cap shows that since 2005, those REITs rated BBB and above have consistently outperformed those rated BB and below. (A 2003 analysis of quarterly returns on 124 U.S. REITS reflected a 10.4\% market value premium for portfolios with superior energy efficiency (Eastern Research Group et al. 2003).
} 
- hedge against competitive obsolescence

- reputation enhancement as a "thought leader"

- ability to meet CSR and Community Reinvestment Act goals

- broadened market opportunities.

\subsubsection{Property Manager}

- market differentiation and reputation enhancement

- reduced exposure to operating expense volatility

- potential for higher revenues due to lower cost structure or benefit sharing with landlord.

- stronger recruiting capability for vendors and service providers due to healthier environment.

\subsubsection{Real Estate Broker}

- market differentiation

- broaden attraction to key client base - especially with Fortune 500 tenants requiring Energy Star, sustainable, LEED, or high-performance buildings.

\subsection{Value Analysis}

The factors that go into making the decision to invest in a specific sustainable property or highperformance measures are inherently no different than looking at any other property type or capital investment. However, what is different is that the assessment needs to take into account the net impact of all costs and benefits related to the high-performance attributes after synergies and risk mitigation measures are considered. Sustainability-related development or retrofit costs might be higher than conventional properties due to costs related to a number of items, including energy modeling and commissioning. Further, in some markets, lack of an integrated design and construction team along with a limited availability of products and materials can increase costs. New modes of operation require a learning curve to get everyone from the contractor through the maintenance team up to speed. These costs can be offset through integrated operational systems as well as utility and governmental rebates and incentives.

Looking at the long-term operational aspects of the property means evaluating the resource use and potential cost reductions resulting from the efficiency measures. Putting the inherent challenges of accurate energy modeling aside, energy forecasts can be difficult — energy price volatility, changing weather, use type, and occupancy factors all impact the quality of the estimate and say nothing about the ongoing durability of the savings. Rigorous monitoring and verification along with robust commissioning, staff and tenant education and training, and an alignment of performance measurements can mitigate this risk.

The financial performance of a property is determined by a number of inputs including rent, occupancy, tenant renewals, operating costs, insurance, and a market estimation of the risk of the property investment (discount rate). The relative impact of each of these factors is critical to the overall analysis. 
For example, rent and revenue-related components would have a more significant impact than operating expenses. However, high-performance attributes that reduce operating expenses have a twofold impact. First, even small reductions in energy, water, and maintenance costs add up and increase net operating income. Second, persistent reductions in those same expenses reduce the operating risk of the property and can have a large impact on the discount rate and resulting value. Further, this limited look does not take into consideration the potential market value of future-proofing against regulatory changes or increased marketability due to sustainable attributes.

A reasonable reduction in energy use and accordingly, operating expenses can be much easier to achieve than increased rents and still have a substantive impact on value. One way to analyze the impact is to use a discounted cash flow (DCF) model over a 10-year horizon. (The DCF is the most likely analysis tool for commercial property investors). By using a DCF, the investor is able to compare, over time, the relative value of the reduced expenses to the annual cash flow and to the ultimate value of the property. Thus a modest reduction in energy efficiency — say 20 or $30 \%$, which can be fairly easily achieved through simple and low cost improvements - can yield a substantial return equivalent to increases in rent, which may be far more difficult to obtain. A simple proxy for the impact of these efficiencies on the value of the property is to capitalize ("cap") ${ }^{1}$ the annual net operating income of a property before and after an efficiency retrofit. Let's look at an example of a 400,000-square-foot office building before and after a retrofit that yields a $30 \%$ reduction in energy costs. In this example (Figure 7.1), a reduction in electricity alone results in reduced operating expenses and an increase in NOI (and cash flow) of $\$ 170,100$. Using an $8.5 \%$ cap rate, this savings increases the value of the building by just over $\$ 2$ million.

\footnotetext{
${ }^{1}$ A quick way to estimate a property's value is to "cap" (i.e., apply a "cap rate") its net operating income. The capitalization rate ("cap rate") is the percentage number used to determine the current value of a property based on estimated future operating income. Net operating income divided by property value $=$ the cap rate. The higher the cap rate, the greater risk the investor perceives with the property returns.
} 


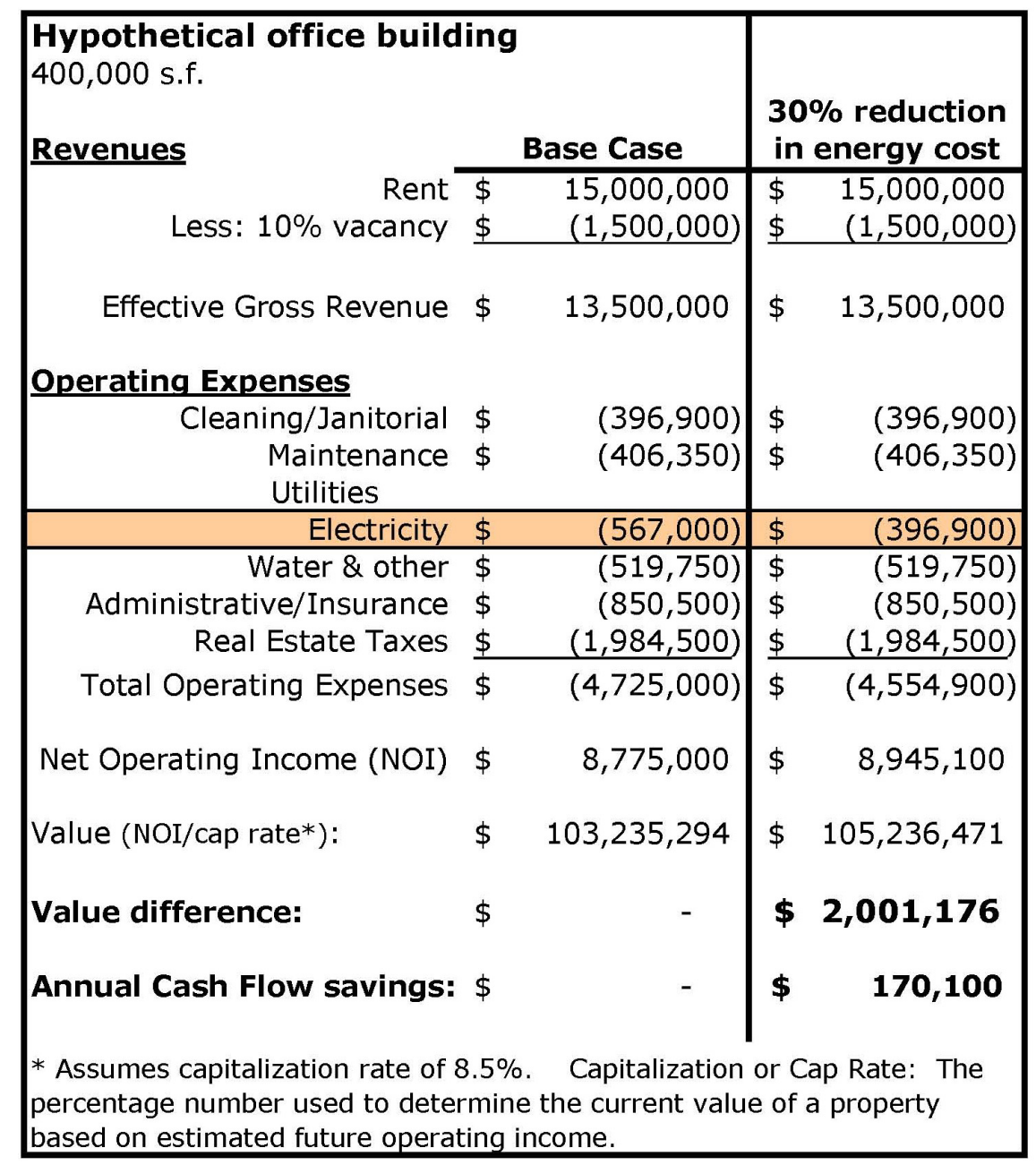

Figure 7.1. Impact of energy efficiency retrofit on net operating income, property cash flow, and value 


\subsection{Building the Tools and Measures}

Moving from talk into meaningful action means increasing investment in deep energy savings, not simply going after the "low-hanging fruit." Emerging ideas and solutions thus far are clustered around education and information transparency; codes, standards and policies; and incentives and financing mechanisms. Crucial in ensuring ongoing success are measurement, verification, transparency, and ongoing monitoring and active management.

Cities such as New York, San Francisco, and Seattle are leading the way on benchmarking and transparency. In 2007, California approved legislation that required benchmarking and limited disclosure as of the first of 2010. In 2008, the District of Columbia went further and required phased-in public disclosure, also starting in 2010. And in what has been called the most sweeping commercial building energy-efficiency legislation, New York City passed the Greener, Greater Buildings Plan ${ }^{1}$ in December 2009. The legislation increases energy efficiency requirements for renovations and requires most properties to undergo energy use audits and retrocommissioning ${ }^{2}$ every 10 years. The audit process will identify capital improvements that will pay for themselves in a "reasonable" period. Perhaps most significant is the requirement that all commercial buildings greater than 50,000 square feet benchmark and publicly report their energy use. The city of Seattle followed suit in January 2010.

\subsection{Market Linkage}

There is a need to link high performance and energy efficiency to the value of the property beyond that which can be achieved in operating savings. In the private sector, efforts to capture these data are centered on linkages between properties that achieve certain levels of Energy Star and LEED ratings and their corresponding rent and sale values. As noted previously, these provide some compelling directional data but are still limited in the size and scope of their results. The U.S. Green Building Council (USGBC) now requires submittal of performance data on properties that receive LEED certification. CoStar, a firm that collects real estate information on the sales and lease rates for commercial properties, has added a screen to its database that includes a check for properties rated as LEED or Energy Star. ${ }^{3}$ The CoStar database notes if a property has received a designation but does not collect data related to property performance. As of December 2009, there were 4,531 LEED-certified projects ${ }^{4}$ and just under 9,000 Energy Star-labeled buildings, ${ }^{5}$ which compares to the EIA 2003 estimate of 4.9 million commercial buildings nationally. However, these still account for only a small proportion of properties.

\subsection{Validating Energy Efficiency}

Supporting efforts to develop more accurate methods of verifying energy use provides clarity around efficiency results and allows private sector capital to finance improvements. A nationally agreed upon standard for determining energy baseline, measurement, and verification, akin to what is anticipated in

\footnotetext{
${ }^{1} \mathrm{http}: / /$ www.nyc.gov/html/planyc2030/html/plan/buildings_plan.shtml.

${ }^{2}$ Retrocommissioning involves retuning measures that ensure building systems are operating efficiently.

${ }^{3}$ www.costar.com.

${ }^{4} \mathrm{http}: / / w w w . U S G B C$.org, fact check February 9, 2010, the vast majority certified at LEED Silver or below.

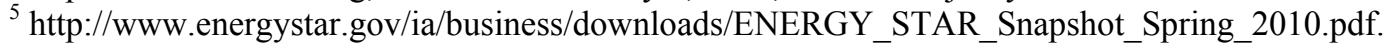


ISO $50001^{1}$ and that targets protocols aimed at ensuring strong persistence of savings, also would help. Certainty around actual energy performance and savings requires increased focus on analytic tools that allow for accurate measurement and transparency of information. Two equally important elements play a role here-metering and operations. Simply getting the design "right" is not enough. There must be measurable performance standards to confirm that the building works and to allow benchmarking against other buildings. The building must be operated and maintained, discrepancies immediately reported and fixed, over its whole life if we are to achieve persistent and meaningful energy efficiency.

Critical in defining which mechanisms are most practically applicable in a given region or for a specific property type are the characteristics of the building stock: Who are the major property owners (government, owner/user, long-term or short-term investors)? What percentage is leased versus owned? What are typical lease structures and terms? What is the energy makeup in a specific region in the country, and how expensive is it? And how much capacity building (of engineers, contractors, builders, architects) is necessary? Some mechanisms will be more successful in urban office building markets and some in rural retail, some in the investor markets, and others with corporate owner/users.

\subsection{Tools}

To monetize energy savings, the savings must be bankable. To be bankable, the investment community must believe in the level of efficiency and that it will be persistent over time, or else they will not invest in or finance the improvements. The notion of savings is predicated on the credibility and credence of a valid baseline. To achieve legitimacy, we need to

- Understand and agree on the baseline.

- Validate the baseline, prove out the energy models, via measurement and verification.

- Track efficiency over time; monitoring and verification equate to transparency.

- Proactively manage efficiency measures through robust O\&M.

Tools that facilitate this level of transparency increase awareness, reduce risk by alleviating uncertainty, and set standards upon which appropriate benchmarks may be based by property type and region. Monitoring and verification, ongoing commissioning and robust maintenance are critical. Through metering and response, they provide both feedback and transparency and enable persistent efficiency, increasing stability and continuity and reducing uncertainty over time. These in turn give comfort to tenants, owners, and investors that the savings are achievable and credible and allow for the efficiency to be monetized and the benefits allocated.

\subsubsection{Industry Consensus Metrics, Third-Party Standards, and Reporting}

Industry consensus metrics verified by a credible third party will ensure transparency and enable sustainability value to be incorporated into value and financing decisions. There is presently no universal benchmark system in the United States. The real estate industry has embraced Energy Star, but additional work is necessary to enhance and create standards that meet all property types. One means of reporting

\footnotetext{
${ }^{1}$ International Organization for Standardization (ISO) Draft International Standard 50001. http://www.iso.org/iso/ pressrelease.htm?refid=Ref1337.
} 
and disclosure could be an energy usage "sticker" (akin to a fuel mileage sticker) affixed to the building or incorporated as part of the building sales or lease package. Given varying occupancy conditions, weather variations, and energy price differences, the information would be specific to both region and property type. Greater impact would be derived by directly correlating the energy usage to the cost over time. Given that most investor/owners retain a property for 3-7 years, a 5-year horizon would be appropriate and would provide sufficient data to smooth operating variations. ${ }^{1}$

\subsubsection{Access to Real-Time Numbers}

Providing the technology and the means to "see" and track the consumption metrics allows owners and tenants to modify activities in ways that avoid peak pricing use and allow for rapid deployment of maintenance staff to fine-tune systems and identify and address operational failures. One means of increasing the visibility of energy use and transparency to building owners and occupants would be some type of "dashboard" akin to that on the Prius vehicle. Metering provides transparency to the owner, the tenant, the investor, and the lender.

\subsubsection{Robust Operations and Maintenance}

Ensure the persistence of the efficiency results through active and effective operations and maintenance protocol. Retrocommissioing, ongoing commissioning, and the means to correct problems as they arise are critical for durable results. Consistent feedback and correction ensures the property is operating at peak levels and enables investment and financing to proceed with greater assurance of returns.

\subsubsection{Monetizing Energy Efficiency}

There must be a market for energy efficiency through which efficiency measures can be monetizedsuch as carbon and/or energy efficiency trading, policies that place energy efficiency at the same level as energy supply, white certificates, or energy performance certificates. This market is yet unproven and considered risky. An agreed-upon baseline methodology to measure energy use and a means to consistently track performance are required. A greater amount of certainty and transparency is needed before private actors will be willing to engage further. Investors, owners, tenants, brokers, and appraisers are pivotal to the market's development. Through its energy performance certificates, whereby property owners are required to measure and disclose energy use of their buildings to potential purchasers and tenants, the European Union (EU) is poised to make significant progress. (Evaluation of the success of this endeavor has just begun; it is anticipated that results will be reported out shortly.) In another example, the IPD Environment Code offers property owners a framework for evaluating the environmental performance of their buildings and sets a standard for comparison across sectors (IPD 2008).

\footnotetext{
${ }^{1}$ The sticker might say something like "As of the current date $\mathrm{xx} / \mathrm{xx} / 20 \mathrm{xx}$ : Based on the current level of occupancy (x\%), existing equipment and machinery and plug loads, energy prices averaging $\$ 0 . x x / k w h$, this building estimated to use $\mathrm{x}$ Btu per year at an annual cost of $\$ \mathrm{x}$.xx per square foot for the upcoming 5-year period." The Zerofootprint Foundation in Canada is in the process of rolling out a voluntary sticker program. Further details can be found in "Let's Do For Buildings What We Have Done For Cars," Dembo 2009) available from http://www.zerofootprintfoundation.org/images/uploads/

Lets_Do_For_Buildings_What_We_Have_Done_For_Cars_US.pdf (September 2010).
} 


\subsubsection{Tenant Engagement}

A key driver in efficiency will be a tenant who identifies high-performance attributes as a best practice. The Office of the Future project is directly engaging tenants through pilot projects that use direct utility incentives to supplement tenant improvement allowances and incentivize tenants to choose efficient upgrades when building out their space. ${ }^{1}$ Once energy demand in tenant spaces is reduced, central systems can be replaced with smaller equipment, thus reducing first costs and the overall energy use of the building. However, the timing must be synchronized with existing business plans, capital improvement plans, and equipment replacement cycles to leverage the opportunity with the property owner. Owner motivation can be enhanced further by leases that allow the landlord and tenant to share in the efficiency gains. ${ }^{2}$ (With reporting standards for energy efficiency leaning toward increased transparency, property owners who have benefited from utility pass-throughs as an additional revenue source likely will see increasing pressure to modify their agreements. Without recognition of this issue and care in drafting new lease structures, these property owners may resist efficiency measures and/or transparency.)

\subsubsection{Public/Private Partnerships}

To leverage private sector participation, governments at all levels need to reach further to create mechanisms that enable more public/private partnerships, risk sharing, and certainty. By linking multiple components in one initiative, public-private partnerships offer strong opportunities to move the market rapidly. One example is the Clinton Climate Initiative (CCI) partnership between 40 international cities, energy efficiency equipment manufacturers, banks, and energy services companies (ESCOs) to provide financing, discounted products, and services to building owners. ${ }^{3}$ (Due to a variety of factors, including the current lack of credit available broadly and a lack of financeable projects, this initiative has not taken off as quickly as anticipated.) Other possibilities include loan guarantees/credit enhancement provided by a government entity to leverage private capital investment; requirements by government-sponsored enterprises (i.e., Fannie Mae/Freddie Mac), the U.S. Department of Housing and Urban Development (HUD), rating agencies, financial institutions, and investors for energy-efficiency certification; and municipalities and utilities offering fiscal incentives for the use of specific green products or reaching and maintaining specific efficiency benchmarks.

\footnotetext{
${ }^{1}$ http://www.newbuildings.org/advanced-design/advanced-energy-office.

${ }^{2}$ Full service gross lease: a lease in which the stated rent includes the operating expenses (including utilities) and taxes for the building. It is the opposite of a triple net lease (NNN). A triple net lease requires the tenant to directly pay, in addition to rent, all expenses of the property, such as utilities, taxes, insurance. The tenant would reap any benefits of lower property expenses.

${ }^{3}$ The Clinton Climate Initiative (CCI) Energy Efficiency Building Retrofit Program is working with 40 of the world's largest cities along with energy service firms and financial institutions in an effort to reduce energy consumption in existing buildings. The CCI has helped initiate more than 250 retrofit projects encompassing over 500 million square feet of building space in more than 20 cities around the world. In addition to municipal properties, the CCI has worked with private building owners including the owners of the Empire State Building in New York City. Working with the Building Owners and Managers Association (BOMA), the CCI has developed an energy services performance contract (ESPC) that addresses the needs of commercial property owners and is also providing owners with the means of entering into a purchasing alliance for energy-efficient products. http://www.clintonfoundation.org/what-we-do/clinton-climate-initiative/our-approach/cities/building-retrofit; http://www.c40cities.org; and the BOMA Energy Performance Contracting Model (BEPC) at http://www.boma.org/resources/bepc/Pages/default.aspx.
} 
These types of partnerships tackle multiple hurdles and leverage the policy impact, driving larger and more sustainable changes.

\subsection{Communication Strategies and Messaging}

Communication strategies must be developed and tailored to investors, owners, managers, and tenants. Delivery must be made by trusted partners and industry leaders. Partnerships that leverage key industry organizations and stakeholders to deliver targeted education, training, and information around specific incentives, financing structures, and tools will reach a far greater audience than through one medium or strictly from one entity. Messaging that educates and looks at high-performance attributes in the context of property operations and the real-life impact on occupants, operations, cash flow, and net operating income is effective — risk and return, health, and safety.

\subsubsection{Messaging}

In a recent study, Attari et al. (2010) surveyed 505 individuals on their perceptions of energy consumption. Results showed participants consistently and substantially underestimated energy use and savings and believed that curtailment (turning lights off) was a more effective strategy than efficiency improvements (new light bulbs). The authors posit that the lack of focus on efficiency improvements was due to the fact that efficiency improvements involve research, effort, and out-ofpocket costs. Further, participants were unable to accurately estimate the magnitude of energy use across devices and activities.

Attari et al. (2010, p. 1) concluded "The serious deficiencies highlighted by these results suggest that well designed efforts to improve the public's understanding of energy use and savings could pay large dividends." The study suggests that understanding the knowledge gaps and misconceptions will enable credible and understandable messages to be crafted that can influence better-informed decisions.

Information leads to awareness, and awareness leads to action. Messages and mechanisms that link multiple components are likely to have wider-ranging impact and be more durable and sustainable by bringing together stakeholders for a common goal. Incorporating meaning that ties to a common goal encourages a viral component to messaging, which is critical to widespread adoption.
The non-profit TED* is a great example of successful messaging that leads to action. The TED motto is "Ideas Worth Spreading." At its core is an annual conference featuring 18-minute talks by leading-edge thinkers and innovators on a variety of topics ranging from green energy to global social issues and culture. What makes it successful in spreading ideas broadly is that in addition to live participation, the talks are available online for free. The ideas are spread by word of mouth, via online videos, and through a variety of social networking tools, including blogs, tweets, and discussion groups. The talks showcase innovative ideas with the potential for farreaching impact-the messages are successful because they link to individual values by making an emotional connection while providing information. The participants are directly engaged and act as influencers in bringing the concepts to a wider audience.

*TED: Technology, Entertainment and Design, www.ted.com. 
So, how can this be successfully applied to incentivizing property owners and investors to invest in high-performance measures?

1. Information must reach the investors most likely to take action and act as influencers.

2. Market research is necessary to better understand the demand patterns going forward. Creating transparency around performance metrics will strengthen both the desire to achieve high performance and facilitate investment by creating certainty around results.

3. Models, programs, and standards that facilitate benchmarking ${ }^{1}$ and help firms identify and set efficiency targets will elevate awareness, enhance competition among properties, and increase investor confidence. ${ }^{2}$

4. Incentives that incorporate both a carrot and a stick to move investors toward certain behaviors.

5. Communication strategies that influence companies and corporate leaders and dispel misinformation. Messaging that concretely links sustainability and high performance with risk and return will prove more impactful than broad concepts.

To scale, messaging must close the gap between the innovators/early adopters (15.5\% the market) and the early majority (34\%). ${ }^{3}$ Bridging this gap brings the idea to the mass market. The innovators and early adopters are comfortable making gut decisions and utilizing an imperfect model. The early majority needs more proof - they want more evidence and will try something after the opinion leaders or respected members of the community have tried it. Messaging must link beyond the "what" (energy efficiency) and "how" (lighting, building orientation) to the "why" (the cause, purpose, or belief). This increases the level of confidence in the decision beyond the rational - "I think this is the right decision" and the gut"this feels like the right decision" to one that incorporates both. "The decision both feels right and can be justified by facts and figures - "I know this is the right decision" (Sinek 2009). Few people make decisions solely on facts and figures. Their fundamental values such as security, freedom, and responsibility play into their decision significantly. Property owners and corporations also operate under fundamental values such as safety, responsibility and reliability, respect for their workers and clients, innovation, and in increasingly more cases, environmental sustainability and community commitment (with the awareness that being a good corporate citizen engenders trust and ongoing corporate sustainability and profitability).

Messages that will resonate with investors will target two key areas - risk and return. Investments by their nature have some inherent risk - some deviation from expected returns - be it opportunity cost, risk

\footnotetext{
${ }^{1}$ The EPA Energy Star program and ANSI/ASHRAE/USGBC/IES Standard 189.1-2009 are good examples. Standard 189.1 is modeled after LEED. Like typical codes, it provides specific requirements for energy efficiency in buildings but extends to other "green building" considerations such as materials selection. The resulting building might look and behave much like a LEED-certified building but is not labeled as such.

${ }^{2}$ One such effort to define sustainability performance metrics is currently being undertaken by Pacific Northwest National Laboratory and the National Renewable Energy Laboratory. These metrics include energy, water, indoor environmental quality, transportation, maintenance, and waste and recycling.

${ }^{3}$ In Diffusion of Innovations, Everett Rogers outlines a study by Bruce Ryan and Neal Gross that provides a welldocumented examination of the diffusion and spread of hybrid seed corn in Iowa in the 1930s. Rogers defines diffusion as "the process by which an innovation is communicated through certain channels over time among the members of a social system" (Rogers 2003, p. 6). The concept has been expanded by Malcolm Gladwell in The Tipping Point (Gladwell 2002) and Simon Sinek in "How Great Leaders Inspire Action" (Sinek 2009), a TEDx, Puget Sound, lecture filmed September 2009 available from http://www.ted.com/talks/lang/eng/ simon_sinek_how_great_leaders_inspire_action.html (September 2010).
} 
of failure, risk of default, lower return. An investment that yields a higher return than another is not necessarily better than the other. One needs to evaluate the overall risk associated with that return and the risk tolerance of the investor. In the case of a property owner, as we move toward an energy-conscious market, the risks associated with an inefficient building can be significant. These include regulatory risk, energy price risk, ${ }^{1}$ energy availability and security, health and wellbeing of occupants, and competitive obsolescence (companies and buildings that are no longer as desirable as others - the perception of being behind the times/not cutting edge or lower performance; workers who look for "cutting-edge firms" and socially conscious firms; occupants/tenants who require sustainable properties).

\subsubsection{Communication Strategies}

Communication strategies may subtly encourage transparency and raise the bar. Look at the results of car labeling and the Corporate Average Fuel Economy (CAFÉ) standards enacted after the 1973-1974 oil crisis. ${ }^{2}$ The sticker is a visible announcement of a vehicle's fuel economy and allows for easy comparison between cars. Another example is the Emergency Planning and Community Right-to-Know Act (EPCRA), cited by Thaler and Sunstein (2008, pp. 190-191). The Act was enacted by Congress in 1986 in the wake of the world's worst industrial disaster in December 1984 at the Union Carbide pesticide plant in Bhopal, India. ${ }^{3}$ The Act requires firms and individuals to report to the federal government the quantity of potentially hazardous chemicals stored or released into the environment. The means of collection is through the Toxics Release Inventory, ${ }^{4}$ which is posted on the U.S. Environmental Protection Agency (EPA) website and readily available to anyone. Nearly 650 chemicals are covered, and more than 23,000 facilities disclose detailed information on their on-site and off-site disposal of chemicals and any potential adverse health impacts. Thaler and Sunstein note that in the intervening years since enactment, the law has resulted in significant reductions in the quantities of toxic substances released across the United States (Hamilton 2005). The point here is that the objective of the act was simple: to allow communities and individuals to know where hazardous materials were being held and to support informed decision-making. The unintended, although positive, consequence is far fewer releases of hazardous materials into communities. What is important here is not the prescriptive policy but what is driving the result: the transparency of the information. No company wants to find its name on a public list of polluters. And those that do tend to take actions to reduce their emissions or ensure they do not end up on the list at all.

This concept is supported by a study done on Los Angeles County restaurants. In 1998, Los Angeles County introduced hygiene quality grading cards that each restaurant was required to display in its window. "The researchers found that the grade cards caused the restaurant health inspection scores to improve, consumers' sensitivity to hygiene in restaurants to increase, and hospitalizations for food-borne illnesses to decrease." ${ }^{, 5}$

\footnotetext{
${ }^{1}$ Johnson Controls (2010b) reflects that property owners anticipate an average annual increase in energy prices of $7 \%$.

${ }^{2}$ http://www.nhtsa.gov/cars/rules/cafe/overview.htm

${ }^{3}$ EPCRA was passed in response to concerns regarding the environmental and safety hazards posed by the storage and handling of toxic chemicals.

http://www.epa.gov/ceppo/web/content/lawsregs/epcraover.htm; http://en.wikipedia.org/wiki/Bhopal_disaster.

${ }_{5}^{4} \mathrm{http} / / / \mathrm{www} . e p a . g o v /$ tri/.

${ }^{5}$ As reported in Thaler and Sunstein (2008, p. 190) who reviewed a 2003 paper by Ginger Zhe Jin and Philip Leslie.
} 
The two examples just presented highlight the positive implications inherent in transparency and reporting. From an energy perspective, this underpins current efforts in the United Kingdom (UK), which require both commercial and residential property owners to provide energy performance certificates (EPCs) to prospective buyers (and tenants). In addition, public buildings must post display energy certificates (DECs) of their energy usage. ${ }^{1}$ In the United States, a number of voluntary initiatives are currently in the works, including one developed by the American Society of Heating, Refrigerating and Air-Conditioning Engineers (ASHRAE) for commercial buildings called Building Energy Quotient, currently in the pilot stage. ${ }^{2}$ Additionally, research at DOE around the use of energy performance certificates in the residential sector is being done. ${ }^{3}$ (It should be noted that some in the real estate industry have opposed an energy labeling concept because of fears that older, less efficient buildings will be labeled as poor performers, and also concerns about difficulty determining appropriate baselines that take into consideration property type, occupancy, usage, and regional weather conditions.)

Increasing awareness, communication strategies, transparency, and labeling are valuable components of an overall strategy to increase investment in high-performance buildings - but they are limited in scope. There also needs to be the means to deploy the improvements that lead to high-performance buildings. Financing is a means to that end.

\footnotetext{
${ }^{1}$ Available through the UK National Archives: http://webarchive.nationalarchives.gov.uk/+/http://www.communities.gov.uk/planningandbuilding/theenvironment/e nergyperformance/.

${ }^{2} \mathrm{http}: / /$ www.buildingeq.com.

${ }^{3}$ http://apps1.eere.energy.gov/buildings/publications/pdfs/corporate/rating_rfi_6_2_10.pdf.
} 


\subsection{Financial and Policy Mechanisms}

This section of the report focuses on existing and potential financing and policy mechanisms, individually and in combination, if scaled, that will help drive deployment of energy-efficiency investment in the real estate sector. It is not all-encompassing; rather, it is meant to identify those mechanisms that currently have the most likelihood of impact and success. It further outlines some of the barriers to achieving success and potential solutions.

Beyond traditional government and utility incentives, some financing mechanisms are cropping up across the country. Some of the new and reformulated ideas include on-bill pay or on-bill financing, energy services companies (ESCOs) and energy services performance contracts (ESPCs), energy and efficiency services agreements, energy efficiency power purchase agreements and property-assessed clean energy (PACE), all of which focus on the retrofit of existing buildings. Some policy mechanisms include energy performance certificates, minimum energy performance standards, renewable and energy efficiency certificates/credits (RECs), carbon offsets, cap and trade, or a carbon tax. On the market-driven front are carbon trading, energy efficiency or emissions trading, and even modified lease structures.

The applicability of each mechanism depends not only on the property type but also on regional context and existing market structures. Currently, the most prevalent are incentives, grants and rebates, and conventional loans for those who can qualify. These structures limit the amount and depth of efficiency that can be achieved. Beyond federal inducements, regional incentive structure, amounts, and requirements vary across the country, making it difficult for portfolio owners to implement a strategy that scales across their assets. For portfolio owners, transaction costs associated with meeting individual program requirements for a single asset can offset the benefits associated with retrofit rebates.

Policy mechanisms could include carbon legislation (cap and trade or a carbon tax), energy performance labeling and disclosure, energy performance standards, and more stringent building codes.

Hurdles posed on the financial side can be pivotal. They include lack of data, first cost, capital versus operating budgets, risk exposure, the low ratio of energy costs to total operating expenses, high transaction costs, discount factor issues, and the inadequacy of traditional financing mechanisms for energy efficiency projects, as follows:

- Most financial institutions are accustomed to an asset-based lending structure and are not equipped to view cash flow generated from energy efficiency as an asset that can be monetized or used as credit enhancement.

- Identifying the means to collateralize the financing of improvements has been challenging (as illustrated by the current issues with PACE $^{1}$ financing). One option is to take the equipment (or efficiency features) as collateral. Difficulties with holding the equipment or improvements as collateral are threefold:

- First, the property owners (at least in the commercial markets) have a contractual obligation with their tenants to provide a specific level of comfort and safety in the building. Hence, they want to maintain control of systems.

\footnotetext{
${ }^{1}$ Property-assessed clean energy (PACE) provides for energy investments to be financed and collateralized through a property tax lien, which has, from the mortgage lenders' perspective, raised issues of priority in collecting debt. Updates on PACE are available from http://www1.eere.energy.gov/wip/pace.html (September 2010).
} 
- Second, any improvements would, by their nature, be affixed to the building (e.g., windows, chillers). As a consequence, they become real property as defined by law. This compares to furniture, fixtures, and equipment, which is considered personal property, not integral to the operations of the building, and which can have a Uniform Commercial Code (UCC) filing ${ }^{1}$ placed on it. Clearly, in the event of a default, it would be impractical to remove many of the efficiency improvements (consider windows, for example).

- Third, mortgage holders take a blanket lien on the real property. They need to ensure the property is able to perform as intended, both while owned by their borrower and in the event of a foreclosure. Consequently, they are not willing to allow anyone else to have a claim on assets that are necessary to keep the building operational.

- In the case of energy per se, there are ordinances related to safety and security that are dictated by local laws.

- Financing periods are generally short (less than 10 years), and interest rates can be high.

Financing remains a critical component in deploying the necessary technology and is a significant hurdle, even if in some cases only a psychological one, to seeing substantial investment in highperformance attributes. Financing mechanisms can be categorized into those currently available in the market (at least to some level) new and innovative structures that attempt to deal with some of the inherent challenges that have limited investment, and finally those that are more government-driven, such as incentives and potential policy changes. These financial mechanisms are listed according to category in Table 9.1.

\subsection{Currently Available Mechanisms}

\subsubsection{On-Bill Pay or On-Bill Financing}

Of the currently available mechanisms, the one that seems to have the greatest potential and where DOE leadership could result in significant progress is on-bill pay or on-bill financing.

Utility-based on-bill pay or on-bill financing (OBF) has great potential for large-scale applicability in both the commercial and residential sectors. The concept of OBF, which has been around for some time yet is still in infancy in practice, is financing offered through the local utility company with repayment made through the client's monthly utility bill. To date, the programs have been structured with the utility company acting directly as the funding source. Consequently, on-bill pay is available on a very limited basis.

\footnotetext{
${ }^{1}$ A UCC filing is made under the Uniform Commercial Code and is a lien placed upon a business or the assets of a business and registered with the state in which the business is located.
} 
Table 9.1. Financial mechanisms

\begin{tabular}{ll}
\hline \multicolumn{1}{c}{ Type } & \multicolumn{1}{c}{ Mechanism } \\
\hline Currently available & On-bill financing (OBF) \\
& Energy services companies (ESCOs) \\
& Power purchase agreements (PPAs) \\
& Revolving loan funds \\
& Utility incentives, grants, and rebates \\
New and emerging innovative strategies & Modified lease structures \\
& Efficiency or energy services agreements (ESAs), managed \\
energy services agreements (MESAs) & Energy efficiency power purchase agreements (eePPA ${ }^{1}{ }^{1}$ ) \\
& Climate benefit districts \\
& Foundation investments \\
Green loans/loan guarantees \\
Property assessed clean energy (PACE) \\
Tenant incentives \\
Government incentives, tax credits \\
Energy performance labeling \\
Energy performance standards \\
Energy trading schemes (ETS) \\
Energy efficiency trading scheme \\
Voluntary carbon trading \\
White certificates \\
Clean development mechanisms \\
\hline
\end{tabular}

The benefits of OBF include a one-stop provider, vetted certified professional contractors, long-term financing, ease of repayment (through a regular billing cycle), and a lien that attaches to the property instead of to the borrower. Further, because both the local municipality and/or utility touch all members of the community, the program could be scaled. In the short run, the scalability of the model is hampered by a financial structure that disincentivizes efficiency, the fragmented nature of the utility industry. In addition to federal regulations, each state has its own overarching requirements for utilities. Many states also have more than one utility. Further, neither the utility nor the municipality has lending (or energy efficiency) as a core business. Consequently, a new core competency and protocol would need to be developed for success.

In the OBF model, a utility company (or some other entity) finances the energy efficiency improvements. The property owner receives the benefit of the efficiency reduction in the form of a partial reduction in his monthly utility bill (although not as great as the actual savings). The difference between the actual savings and the rate paid by the property owner presumably is sufficient to amortize the cost of the improvements plus some interest rate to the utility. The obligation runs with the property, attached to the utility bill, and would be passed along to subsequent purchasers.

\footnotetext{
${ }^{1}$ The term eePPA has been trademarked by Equilibrium Capital Management.
} 
Two potential roles that DOE could play in facilitating on-bill pay programs are

1. Work with the Edison Electric Institute or other utility groups (e.g., the National Association of State Energy Offices [NASEO], the Office of the Future ${ }^{1)}$ to address the misalignment between profit and efficiency, develop protocols, and model documentation for utilities nationwide.

2. Facilitate a pilot program with a third-party provider who would provide funding through the utility as well as ongoing management of the billing and servicing of the financing (including development of the enterprise software that would be necessary to modify existing billing systems.

\section{On-Bill Pay - An Example}

Sempra Energy in San Diego, California, offers a program to both business and tax-funded clients (http://www.socalgas.com/documents/business/rebates/2010OnBillFinancing.pdf). The funding amount varies, however; for commercial property owners, it is a maximum of $\$ 100,000$ per meter and must be repaid within 5 years, limiting the amount of deep efficiency retrofit. If the property is sold or the bill-payer occupant vacates the space, the loan must be repaid immediately. The repayment upon sale requirement by Sempra limits the applicability of this mechanism to investor-owned commercial properties.

\subsubsection{Energy Services Companies}

An energy services company (ESCO) provides energy-efficiency-related and other value-added services to building owners. Performance contracting is a core part of its energy-efficiency services business. ESCOs ${ }^{2}$ have been around since the late 1970s and early 1980s when energy prices spiked after the Arab oil embargo. Although a relatively young industry in the United States, they have been around in Europe for about a century. They typically provide four main services: the development, installation, and arrangement of financing for energy efficiency improvements and then, through an energy services performance contract (ESPC), ongoing maintenance, operation, and a guarantee of energy savings. The cost of the improvements is paid from the savings generated by the efficiency.

Through an ESPC, the ESCO "guarantees" the project will maintain a stipulated level of energy savings over a certain period - anywhere from 7 to 20 or even 25 years, based upon specific parameters such as load, usage patterns, hours of operation, and maintenance. The ESCO model has worked almost exclusively in the so-called MUSH market, ${ }^{3}$ which along with federal government clients, accounts for about $84 \%$ of total revenues for the ESCO industry. Due to the nature of the financing structure, the applicability of the ESCO model is generally limited to an entity with a desire for outside financing, a high credit rating (generally investment grade), and planned continued ownership.

\footnotetext{
${ }^{1}$ A consortium of utilities in partnership with the New Buildings Institute (www.newbuildings.org).

${ }^{2}$ The DOE Federal Energy Management Program has developed lists of ESCOs for federal projects that either 1) have competed and been awarded a master DOE ESPC contract and/or 2) have been screened by a qualifications review board. For links listing these firms, visit http://wwwl.eere.energy.gov/femp/financing/espcs_companies.html.

${ }^{3}$ The MUSH market comprises municipalities (state/local governments), universities, K-12 schools, and hospitals.
} 
In 2006, ESCOs in the United States did about $\$ 3.5$ billion in business, the majority of it with government clients. Between 2006 and 2008, the ESCO market grew at about 7\% per year. Based on analysis by the National Association of Energy Service Companies (NAESCO), ${ }^{1}$ the market is anticipated to grow $26 \%$ annually between 2009 and 2011 . More than $69 \%$ of the market comes from the MUSH sector. The federal market accounts for an additional 15\% of business. Key drivers of the increase in the MUSH market include the large amounts of funding from the American Recovery and Reinvestment Act of 2009 going into state and local government energy efficiency programs. The combination of institutions who own their own buildings, are considered low risk, are subject to legislative-, policy-, or philosophy-driven efficiency/sustainability objectives, and are capital/budget constrained make this a prime market for ESCOs and others who want to finance this sector.

ESCO engagement in the commercial market is slightly higher than the industrial market; however, at $9 \%$ of revenues, it remains a relatively small market segment. According to a report published by the Lawrence Berkeley National Laboratory (LBNL; Hopper et al. 2007), significant barriers limit ESCO activity in the commercial sector. These include

- "misplaced" or "split" incentives that separate the responsibility for making capital investments from paying operating costs and consequently limit the owners' interest in long-term performance contracts

- the relatively short terms of tenant leases (e.g., 1 to 5 years)

- high investment hurdle rates for non-owner-occupied commercial space

- the unwillingness of some owners to take on long-term debt, which might interfere with their ability to sell their properties.

In addition, although not included in the LBNL report, private commercial property owners report a distrust of the energy savings purported to be achieved by the ESCOs as well as an unwillingness to "give away" excessive economic returns. As noted previously, the inability to maintain persistent energy efficiency over time is common. Most buildings and facilities exhibit the same basic limitations with respect to energy conservation and optimum maintenance.

U.S. government studies show that due to the lack of ongoing commissioning and robust maintenance, building systems routinely fail to meet performance expectations, and these faults often go unnoticed over time. For example, a 2005 report released by the U.S. Government Accountability Office (GAO) validates the concerns raised by private property owners. The study, which looked at federal ESPCs, suggested there might not be sufficient data to prove that the gains delivered by ESCOs were sustainable over time. The report further questions the practice of having ESCOs monitoring and validating the performance of their own projects (GAO 2005). ${ }^{2}$

The LBNL report (Hopper et al. 2007) shows that residential and public housing markets together account for only $5 \%$ of industry revenues and are targeted by only a handful of ESCOs. Due to high transaction costs and institutional barriers in the case of public housing, these remain a niche market for

\footnotetext{
${ }^{1}$ www.naesco.org.

${ }^{2}$ The Office of the Under Secretary of Defense for Technology, Acquisition, and Logistics agreed with the GAO findings, stating "Although these complicated contracts are structured to ensure that savings will exceed costs," and further, "we recognize that our measurement and verification procedures must be improved to confirm estimates with actual data."
} 
ESCOs. In small-size properties, the energy cost savings are generally not significant enough to offset the transaction costs inherent in implementing performance-based contracts.

The core market in which the ESCO business model has been most successful is in energy efficiency retrofits to large buildings owned primarily by institutional clients. There is increasing interest in energy efficiency and clean energy among municipal governments that are pursuing sustainable energy and/or climate change initiatives. Recent examples include the participation of several large ESCOs in the CCI Energy Efficiency Building Retrofit Program, which involves 40 cities. Through the standardized protocols developed by the CCI, there is potential to reduce some of the inherent transaction costs, presumably allowing the ESCOs to participate more fully in the commercial markets. Despite great initial promise, the efforts here have not yielded much change in the investment patterns to date. The most wellknown project undertaken to date under this program is the retrofit of the Empire State Building. ${ }^{1}$ It is clear there are untapped opportunities in both the residential and commercial markets that will require some sort of aggregation of small projects to reduce the transaction costs.

In addition to providing financing, an ESCO provides energy audits, recommendations, and performance contracting as a core part of the business. The majority of the market is driven by federal, state, local, university, and educational projects. Barriers in the typical commercial and/or residential real estate markets include the high transaction costs per project, credit-worthy borrowers (single-family residential and/or multifamily, along with single-asset partnerships and an expectation of non-recourse debt) and an inability to adequately secure the loans (collateral and first mortgage-holder challenges). From the borrower/property owner perspective, ESCOs are not always viewed as being transparent. The ESCO industry is dominated by product manufacturers who combine the energy audit with purchase recommendations and ultimately sell their products to meet the needs identified through the auditpotentially an inherent conflict of interest.

The concept behind the CCI Energy Efficiency Building Retrofit Program offers is an opportunity to overcome the obstacles on a large-scale basis. The CCI has partnered with the Building Owners and Managers Association (BOMA) to overcome some of the performance contract hurdles and is working with the financial institutions, to manage the collateral and investment challenges. The BOMA and the $\mathrm{CCI}$ have put forth a performance contract ${ }^{2}$ document for use by the commercial sector. The means of identifying appropriate collateral in the absence of a credit worthy borrower continues to be challenging.

\subsubsection{Power Purchase Agreements}

In simplest terms, a power purchase agreement (PPA) is a legal contract between an electricity generator and a purchaser of energy or capacity (power or ancillary services). ProLogis ${ }^{3}$ has entered into several of these types of contracts in the EU (Spain, Germany, France, Italy, and the UK) through feed-in tariff laws that promote investment in renewable energy. Under the EU feed-in tariff laws, regional or national utilities are obligated to purchase renewable energy at rates set by the government based on the cost of the generating the renewable power. ProLogis also has a PPA in place for two of its properties in California (ProLogis 2010). The ProLogis properties have incorporated solar panels onto their rooftops (typically flat, industrial properties) and have entered into 20- to 25-year agreements to sell energy back

\footnotetext{
${ }^{1}$ www.esbsustainability.com.

${ }^{2}$ http://www.boma.org/resources/bepc/Pages/default.aspx.

${ }^{3}$ Prologis is a large real estate developer/owner of warehouse facilities globally.
} 
to the utility grid. In the case of the Southern California property, the sales price to the utility is based on the amount of energy produced by the rooftop. The properties are metered and send a bill to the utility on a monthly basis.

\subsubsection{Revolving Loan Funds}

Revolving loan funds deploy public sector capital to meet needs that contribute to the public good. They are applicable to commercial, residential, and neighborhood buildings. Generally speaking, these funds supplement private capital in areas where private capital is less available. A revolving loan program (similar to a community development block grant) lends money and earns a return on their capital. As loan funds are repaid, the principal and interest are added back into the fund and become available for future projects. These funds also can be used in conjunction with private sector capital to leverage project financing.

One such municipality currently using this tool to combat climate change and encourage energy efficiency is the Toronto Atmospheric Fund (TAF). ${ }^{1}$ Originally endowed by public funds in 1992, TAF, which is run by an agency of the City of Toronto, has innovated a program called the Green Condo Loan and Towerwise (both targeted at high-rise apartments and condominiums) whereby efficiency loans are made to the condo association for the building efficiency measures and repaid by the residents/owners via their energy bill savings. The TAF developed a loan concept, the energy retrofit STEP Loan, which facilitates deep efficiency. The STEP Loan is essentially three loans rolled into one: a short-term loan covering fast payback items (like lighting); a medium term-loan for items with a mid-term payback (e.g., HVAC equipment); and a long-term loan for items with long paybacks (e.g., cladding).

\subsubsection{Utility-, Federal-, and State-Based Incentives, Grants, and Rebates}

Utility-, federal-, and state-based programs offering incentives, grants, and rebates are available fairly widely throughout the country to facilitate limited energy efficiency improvements to commercial, industrial, institutional, and residential buildings. These often take the form of rebates or tax credits for lighting, windows, or insulation. A comprehensive database of utility, state, and federal incentives (e.g., rebates, tax credits, grants) is available at the Database for State Incentives for Renewables and Efficiency (http://www.dsireusa.org). These incentives provide an easy entree for property owners to test out basic efficiency measures. They enable many projects, especially renewables such as solar, to get done that would not ordinarily be accomplished due to the high initial cost and long payback. The programs typically arise out of "public good" initiatives from the state public utility commissions or state legislatures. On the downside, they typically take the form of upfront incentives that do not require ongoing monitoring that would ensure persistence. These types of incentives target what has been termed as the "low-hanging fruit" (least expensive, easy to do, quick results; e.g., lighting) and can dissuade property owners from doing deep retrofits that could both save substantial energy and money over time.

A further discussion of federal, state, and local incentives and policy is provided in Section 9.3.

\footnotetext{
${ }^{1}$ http://www.toronto.ca/taf/ and http://www.toronto.ca/taf/pdf/leveraging-leadership.pdf and www.towerwise.ca.
} 


\subsection{New and Emerging Innovative Strategies}

Three strategies have emerged at the forefront of efficiency financing. The first and most widely publicized is property assessed clean energy or PACE. PACE focuses primarily on the residential markets and recently was dealt a setback when the financing community raised concerns over its impact on mortgage debt. Two other strategies are rapidly gaining traction in the commercial property sectorthe first, energy services agreements (ESAs) (or managed energy services agreements [MESAs]) is a modification of the more traditional ESCO structure, which has been so successful in the MUSH markets. The ESAs focus primarily on energy efficiency retrofits versus other limited resources or generation capacity and new construction. ESAs have been utilized in a few cases in the Northeast, and applications throughout the country are being evaluated. Climate benefit increment financing (CBIF) or climate benefit districts (CBD) look to finance a broader mix of resource efficiency and generation capacity and take a neighborhood or multi-property approach rather than an individual building. CBIF is a based on the concept of tax increment financing for neighborhood infrastructure projects. A few pilot CBD projects are being pursued across the country (e.g., Oregon and Colorado). CBD financing has large potential but has not yet been proven.

Not a typical financing strategy per se, but equally on the forefront of activities that address value, modifying leases to engages tenants and expand participation in efficiency has surfaced as a key opportunity to drive investment.

\subsubsection{Modified Leases}

One seemingly simple financial mechanism for commercial and multi-family buildings would be lease modification, both on new leases as well as existing ones to deal with the split of benefits arising from efficiency measures. Lease roll-over differs by property type and location; however, if the majority of leases is assumed to roll within 7 years, it is possible that a concentrated effort to change the language in all new lease documents to encourage a split on the reduced energy costs due to efficiency measures that keep the tenant whole, or even in a lower-cost position, could turn the tide.

Several efforts to define a "green lease" and create a model that can be tailored have been undertaken in the last 12 to 18 months. Recent efforts include 1) the Real Property Association of Canada (REALpac) Green Office Lease $;{ }^{1}$ 2) the BOMA Green Lease Guide; 3 ) the Natural Resources Defense Council (NRDC) Green Lease Forum, which aimed to create a set of principles for lease negotiations and other recommendations for making existing leases more energy efficient; 4) The Model Green Lease; ${ }^{2}$ and 5) the USGBC Green Office Guide. ${ }^{3}$ Defining the scope of building operating expenses is a major green leasing challenge, ${ }^{4}$ particularly with respect to landlord-initiated capital improvements to the building's infrastructure during the term of the lease and as reflected in split incentives. Hermes in the UK has made some efforts to introduce a green lease. Interestingly, the company has encountered adverse reaction from some tenants. What is particularly noteworthy is that some tenants with impressive CSR statements and corporate websites advertising their sustainability credentials have been very

\footnotetext{
${ }^{1} \mathrm{http}: / /$ www.realpac.ca/green-office-leases/.

${ }^{2}$ Developed by The Model Green Lease Task force headed by Alan Whitehead; http://www.squarefootage.net/TMGL.html.

${ }^{3} \mathrm{https} / / /$ www.usgbc.org/ShowFile.aspx? DocumentID=6429.

${ }^{4}$ Especially as related to a full service gross lease.
} 
reluctant to agree to even the simplest of clauses aimed at mutual cooperation and expressed concern the firm is undertaking sustainability improvements with long payback periods at their expense. Hermes has had positive responses as well, and the introduction of the lease has provided a unique way to engage on the subject with a variety of corporations.

\subsubsection{Energy and/or Efficiency Services Agreements and Managed Energy Services Agreements}

The newest financing concept to be utilized for efficiency in commercial and industrial buildings is the energy services agreement (ESA). These take different forms including the managed energy services agreement (MESA), efficiency services agreement (ESA), and energy efficiency power purchase agreement (eePPA). These financing mechanisms leverage off the same base. All provide a solution that requires no up-front capital from the property owner and are transactions off the balance sheet. Owner equity is replaced with third-party financing covering all project costs. In return, the provider receives some portion of the efficiency benefit in the form of a services payment. The provider initiates and maintains the contractual relationship with the efficiency retrofit contractor and handles ongoing management of the systems. The client continues to pay the energy bill plus an energy services payment to the provider, who takes a fee for managing the process and repays the debt and equity. The combined net payment is intended to be equal to or less than the pre-retrofit energy cost. The amount of benefit recognized by the property owner can be anticipated to be higher in expensive energy markets and lower in less costly ones. In some cases, the provider owns the efficiency equipment, and the fee goes to pay for the ongoing operation and maintenance of the systems.

The ESA expands the ESCO model to property owners outside the MUSH market, primarily in the industrial property segment. The MESA model delivers efficiency improvements to landlords of multitenant properties, primarily offices, and steps between the utility company and the client to deliver a single consolidated utility bill equal to historical cost. The savings generated from the efficiency are used to repay the debt, equity, and the service fee without impacting the structure of the leases in place. Both ESAs and MESAs target efficiency improvements between $\$ 1$ million and $\$ 4$ million, with terms up to 10 years.

\subsubsection{Energy Efficiency Power Purchase Agreement}

Expanding the model through what could be called an energy efficiency power purchase agreement (eePPA), the provider pays the owner of commercial and industrial properties a site host fee for housing the efficiency improvements. The provider pays for all improvements and provides continuous performance through $M \& V$ protocols, real-time monitoring, and vigorous O\&M practice. Through the eePPA, efficiency is utilized by the utility as a resource. The property owner and the provider share in the benefits created by the efficiency generated by the property. Through ongoing commissioning, maintenance, and operation of the efficiency improvements, the building continues to operate at intended design efficiency over the long term. This mechanism allows for deep efficiency retrofits and is financed over a longer period, 15 to 20 years.

Revenues from energy efficiency financed projects appear to be both predictable and consistent. In 2008, a study was begun that was to evaluate the correlation between rising energy prices and mortgage default rates. Although the study was never published and there is no way to verify the data, anecdotally 
the initial results indicated that for each $1 \%$ increase in energy costs, there was a corresponding $1 \%$ increase in the mortgage default rate. Therefore, properties and/or loans that incorporate energy efficiency measures should reflect a lower risk profile. ${ }^{1}$

At least one private equity firm ${ }^{2}$ is looking at ways to harness this lower risk profile - to structure and aggregate a portfolio of loans (or investments) to reach sufficient scale and ultimately sell into the secondary market in the form of a securitized product. Primary investors are anticipated to be utilities, socially responsible funds (the socially responsible investing industry) along with insurance companies and union-based pension funds. The premise of the structure is to "expand the pie" by valuing energy efficiency at least the same level (or even subsidized to raise the value) as purchased energy sources (avoided cost). This type of model works best in a high energy cost environment and one in which the utility revenues are decoupled from energy sold (NREL 2009). ${ }^{3}$ The source of financial capital to pay for the efficiency improvements (essentially the delta between the conventional or existing energy use and the deep efficiency resulting from the high-performance attributes) is a combination of efficiency sold to the utility in the form of an eePPA and a premium over the actual use (still less than the conventional cost) paid by the property owner. The combination of these two sources of ongoing cash flow provide for the ability to do deep ( $>40 \%$ ) efficiency and finance it over a fairly long period (7 to 12 years).

In one possible model,

- Energy use in the building would be baselined for comparative purposes.

- Investors would buy, own, and manage the "energy savings generators" in the building.

- Private equity owners would measure and sell the "efficiency generated energy" through PPAs back to the utility.

- Building owners get paid as "site hosts" for the "energy savings generators" (essentially a lease payment for space usage.) Further, they receive ongoing lower energy costs in operating efficiencies.

To prime the market and prove the returns, the model may require a public partner to make an initial purchase of the long-term debt and for the debt to be warehoused and bundled for sale to private investors.

To reach maximum potential, this model requires the utility to value the energy efficiency at least on par with the use of energy, a substantial hurdle in many markets at present. Given this disaggregated nature of the utility markets across the United States, some markets such as California are more likely to achieve parity before others and, as such, provide a greater potential for this model to be successful in the near term.

\footnotetext{
${ }^{1}$ Hiskes J, August 27, 2010, "Fannie Regulator Digs in on Energy Opposition” Grist http://www.grist.org/article/2010-08-27-exclusive-fannie-regulator-digs-in-on-clean-energy-opposition/ ${ }^{2}$ Hannon Armstrong Capital, LLC.

3 "Decoupling is a rate adjustment mechanism that breaks the link between the amount of energy a utility sells and the revenue it collects to recover the fixed costs of providing service to customers. This ensures that a utility's revenue from fixed costs remains at the level regulators determine to be fair and reasonable, including a fair return on investment and that customers pay a fair amount for services rendered" (NREL 2009, p. 1).
} 


\subsubsection{Climate Benefit Districts/Climate Benefit Increment Financing}

In a traditional project structure, financing is segregated between the building core and shell and the district energy. A typical commercial building has its own energy conversion plants (chillers, boilers, furnaces) that serve only the heating and cooling energy needs of the building itself. In a climate benefit district, the district spans the boundary with the efficiency structure integrated into the buildingsdistrict-wide green infrastructure and green power production on site. Each building's efficiency and generator components support the entire district. From a financing perspective, - the funder looks at a district-wide investment profile rather than to the individual buildings (both, commercial and communitywide neighborhood), essentially aggregating and monetizing the difference between neighborhood baseline energy and high-performance use. Essential components for success include demand reduction through building efficiency, new supply through recovery and generation, and neighborhood (public realm) integration.

To function, a climate benefit district (CBD) is formed and designates a managing entity, similar to a homeowners association, to operate the district, which can receive and distribute revenues, and which is a financeable entity, thus providing access to capital for high-performance, district-level infrastructure and shared facilities. Each building within the district provides efficiency (and generators in the form of on-site power - solar, wind, or other) for the benefit of the whole. Property owners would benefit from revenue sharing, after debt service, from the monetization of excess efficiency the district.

Opportunities provided by the CBD:

- Creates an investment that leverages public and private resources to manage growth pressures and improve environmental performance.

- Merges public/private resources:

- government bonds

- local benefit charge on property owners

- distributed portfolio of sustainability devices.

- Aggregates and smoothes efficiency performance, creating more reliable and consistent resource supply and financial returns.

- Reduces aggregate cost across the district.

Obstacles to overcome:

- May require legislative approval to form a benefit district.

- Need to demonstrate a consistent return on investment that attracts the right mix of public and private financing.

- Districts are financially successful only if properties are operating at peak efficiency, which is impacted by occupancy, use, load variations, and maintenance.

- Return requirement threshold for investors/lenders/bondholders is unclear.

- Allocation of benefits between property owners, which is also affected by occupancy, use, load variations, and maintenance, must be done appropriately. 
- The CBD will likely need to be collateralized through contractual agreement with the district rather than a lien on real property.

- Relatively short building ownership durations lead to the need to develop protocols for rights and obligations upon property transfer.

\subsubsection{Foundation Model}

The foundation model is applicable to residential and possibly commercial buildings. Under the U.S. tax code, foundations are required to distribute $5 \%$ of the fair market value of their "non-charitable use assets"1 for administrative expenses and grants to independent public charities (often for capacity building) and below-market loans. There is a potential for large foundations, perhaps in partnership with major corporations, to fund a financing initiative. This concept has been vetted with some foundations, but has not been actively pursued. It warrants additional analysis; for example:

- $\$ 500$ million - \$250 million to get contractors trained and on board; $\$ 250$ million to finance improvements

- 5-10 year ramp-up

- Helps move through economic crisis, provides job creation.

- Has potential to partner with corporations with a 5-year funding commitment (e.g., below-market loans or grants).

\subsubsection{Green Loans/Loan Guarantees}

Like the challenges with the ESCO model, green or energy efficient loans are hampered by the limitations of existing mortgage structures: first lien holders reluctant or unwilling to allow a second lien, lack of collateral and borrower credit capacity. One particular concept that has raised interest is the energy efficiency line of credit, allowing for drawdown over time as need and opportunity arise. Further analysis of this concept is warranted because it would allow for retrofit over time as small commercial tenant spaces vacate and equipment reaches the end of its natural life. (The downside is that this structure could preclude deep retrofit if equipment were simply changed out rather than a holistic look at the entire building systems and structure taken and wholesale changes made.) Loan guarantee or credit enhancement provided by either federal or state agencies (e.g., Pennsylvania Housing Finance Agency, the DOE) or through a new insurance product would also be supportive. The DOE currently has a loan guarantee program that applies to industry. With legislative changes, this could be modified to incorporate energy efficiency in buildings.

A first-mortgage product previously offered by Fannie $\mathrm{Mae}^{2}$ provides a possible template for a loan product. The Fannie Mae Energy Efficiency Loan added up the cash savings anticipated from the future energy savings (over 26 years) from the efficiency improvements. This amount was then discounted to a

\footnotetext{
${ }^{1}$ Generally, stocks, bonds, certificates of deposit, and other investments that make up a foundation's endowment.

${ }^{2}$ The Alliance to Save Energy includes a list of consumer loan opportunities. Nothing similar exists for the commercial market. http://ase.org/section/_audience/consumers/refinanceremodel/refinancing/.
} 
current value ${ }^{1}$ to come up with a lump sum figure. This lump sum figure was assumed to be cash and added to the down payment of the property for purposes of evaluating the borrower's credit and for determining upfront fees and interest rate, hence reducing the risk to the borrower.

Given the small size of many energy efficiency loans, most of the programs can be localized. Community development banks have the potential to play a major role in rolling out energy efficiency loans, especially to the small commercial sector. However, because this has been tried primarily in the residential sector, looking at an example from that market gives an idea on how this might be scaled into the small commercial sector.

\subsubsection{Private Sector Example: ShoreBank Corporation, Chicago}

ShoreBank Corporation has provided financing to low-income residents in Chicago for energy efficiency measures. Typically the loans are part of a transaction in which the purchaser is applying for a mortgage loan. ShoreBank offers to do an energy audit for free and to incorporate the costs of the improvements into the mortgage loan. In most cases, the estimated energy savings are sufficient to offset the potential increase in mortgage interest. The borrowers are free to choose their own contractor and do the improvements. ShoreBank does not regulate the contractor or do any verification or monitoring. ShoreBank also has partnered with a foundation to offer a loan/grant combination. In this case, the corporation has predetermined a specific set of improvements such as water heaters and insulation and has an approved list of contractors to work. This program garnered significant interest but was limited in its applicability due to income and property type restrictions.

\subsubsection{Public Sector Example: The Carbon Trust}

Through the Carbon Trust in the UK, ${ }^{2}$ commercial property owners can borrow, interest-free, up to $£ 100,000$ to finance renewable energy equipment. Any project that can demonstrate a payback period of less than 5 years is eligible. These renewable energy interest-free loans offer the following features:

- loan rate - interest-free

- loan amount - $£ 3,000$ to $£ 100,000$, with repayments based on the anticipated energy savings

- candidate projects - any project that can demonstrate an energy saving with a payback of less than 5 years (e.g., air conditioning, boiler, insulation, lighting, process controls).

- candidate borrowers - private sector organizations that have been trading for at least 12 months and have an acceptable credit rating and fall within the definition of a small to medium-size enterprise in England or Scotland and any business in Wales or Northern Ireland.

\subsubsection{Property-Assessed Clean Energy}

There has been a groundswell of activity around property-assessed clean energy (PACE) in the last 12 months. In October 2009, Vice President Biden announced ${ }^{3}$ that through competitive grants, federal

\footnotetext{
${ }^{1}$ The net present value of a series of payments (26 years in this case) recognizes that the present value of $\$ 1.00$ today is higher than that same $\$ 1.00$ if received 26 years from now.

${ }^{2} \mathrm{http} / / / \mathrm{www}$. carbontrust.co.uk/cut-carbon-reduce-costs/products-services/business-loans/pages/loans-faqs.aspx.

${ }^{3} \mathrm{http}: / /$ www.whitehouse.gov/assets/documents/PACE_Principles.pdf.
} 
monies would be available under the Energy Efficiency and Conservation Block Grant (EECBG) program for retrofitting real estate. Many communities targeted the use of PACE-based financing when applying for the grants, and most focused on residential properties. In conjunction with financial providers, DOE (along with HUD, the National Economic Council, and the Council on Environmental Quality) designed a 24-month trial initially slated to begin in mid-2010. ${ }^{1}$

Although PACE has been targeted primarily at residential properties, it could also be used in the commercial markets. New York City, San Francisco, and Los Angeles in particular have targeted the use of PACE financing for commercial properties in addition to residential.

One of the barriers to wide-scale implementation of PACE in both the residential and commercial markets has been the nature of the lien priority. A number of mortgage lenders have balked at an additional priority coming before repayment of their collateralized loan. In June 2010, both Fannie Mae and Freddie Mac stated that they would not purchase loans that included a PACE lien, effectively putting the brakes on PACE nationally. Fannie and Freddie's operational guidelines, like those of most lenders, require them to sit in a first-lien position on any property. Some lenders have declined to refinance loans that have PACE financing in place. As a consequence, San Francisco has terminated its residential program and is questioning whether or not to continue with the commercial one. The ruling by Fannie Mae and Freddie Mac has placed property owners with this type of financing at risk relative to what will happen when they try to sell their properties. This decision by Fannie and Freddie has put PACE financing (and its use for the federal EECBGs) in limbo. In July 2010, the State of California filed suit against Fannie Mae and Freddie Mac to preclude them from redlining properties that carried PACE financing. Ultimate resolution is unclear.

PACE provides cities, counties, and special districts with the ability to designate a community or region where property owners may enter into a voluntary contractual assessment to finance energy and water efficiency or renewable energy improvements fixed to real property. PACE emerged in California in 2008 out of work that was initially done for the city of Berkeley ${ }^{2}$ to finance residential solar systems and energy efficiency. The nature of the PACE vehicle requires enabling legislation both at the state and the local level. It is now authorized in 22 states and the District of Columbia.

In simple terms, PACE is a way to finance energy efficiency retrofits or solar systems. Essentially, the municipality loans money to owners to make improvements to their property. To secure the loan, a lien is placed on the property in the form of an additional property tax assessment. Liens are repaid via an add-on to the property tax bill at an established rate of interest over a specific period, generally 20 years. The lien remains with the property, even upon sale, until fully repaid. The lien sits in priority to the property's first mortgage. Energy savings that flow from the improvements directly benefit the owner.

The initial thrust of PACE financing has been on the residential market, although several initiatives have begun to push into the commercial sector. The city of San Francisco has approved $\$ 150$ million to

\footnotetext{
${ }^{1}$ In July 2010, federal banking regulators (the Office of the Comptroller of Currency and Federal Housing Financing Agency) determined that structure of the PACE financing during the trial period would cause mortgage defaults due to lien priority and are requiring further consumer and lender protections, borrower financial tests among other items. The PACE concept enjoys broad appeal and support. It remains to be seen how these structural details will be worked out.

${ }^{2}$ BerkeleyFIRST.
} 
support PACE financing, which includes the potential for commercial properties to apply. In further support, the state of California approved a $\$ 50$ million fund to provide credit enhancement toward the issuance of PACE bonds.

Although they vary on the particulars, the PACE programs incorporate the following features:

- Financing is long term and lower cost. Property owners would be able to get 20 years to pay for solar photovoltaic or energy efficiency installations (thus far, the focus has been primarily on solar rather than efficiency). The interest rate on the loans is priced off the city's municipal bond rate, its own cost of capital, generally lower than an individual consumer's typical cost for credit. Depending on the improvements made, the property owner may benefit from the investment tax credit. Further, interest payments may be deemed to be tax-deductible.

- Credit is driven by tax capacity. The homeowner's credit rating is not a qualification factor-the property's tax capacity is.

- Loan stays with the property. The repayment obligation stays with the property upon sale, so the loan benefits are transferable. Property tax liens have priority over first mortgages.

\subsection{Government- and Policy-Supported Mechanisms}

Government-, utility-, and policy-supported mechanisms provide the foundation for the existing efficiency market. These programs not only raise awareness around high-performance opportunities, they also often provide the impetus for property owners to test-drive basic improvements. These mechanisms have been the driving force for engagement and deployment. By their nature, the incentives focus on the "low-hanging fruit" and least-expensive measures. Consequently, these can have a perverse effect on deep efficiency by taking some of the "easy" wins that, when combined with substantive efforts, make the financial returns more acceptable. Policy measures, particularly those in the municipal and state markets, have and will continue to be some of the most significant drivers of greater efficiency in resource use through their combination of incentives and prescriptive nature.

\subsubsection{Utility and Government Incentives}

A number of utilities and federal, state, and municipal entities are offering a variety of tax incentives such as credits and rebates to incentivize investment in energy efficiency measures ${ }^{1}$ in commercial and residential buildings. These activities are very beneficial in supporting investment in this sector and in driving public/private partnerships. They are however, generally limited to the "low-hanging fruit"-the relatively easy and inexpensive solutions that do not go very deep and are often not persistent in their savings. What they do provide is an easy method to enter the market and gain initial traction.

\subsubsection{Example: Green Roofs - United States and Germany}

Under a bill (\#A11226²) passed by the New York legislature in 2008, building owners in New York City who install green rooftops on at least $50 \%$ of available rooftop space can apply for a 1-year property

\footnotetext{
${ }^{1}$ A full description of both governmental and utility incentives is available from the Database of State Incentives for Renewables and Efficiency at http://www.dsireusa.org.

${ }^{2} \mathrm{http}: / / \mathrm{www} . \mathrm{nyc} . \mathrm{gov} / \mathrm{html} / \mathrm{dof} / \mathrm{html} / \mathrm{pdf} / 08 \mathrm{pdf} /$ green_roof_legislation.pdf.
} 
tax credit of up to $\$ 100,000$. The credit will be equal to $\$ 4.50$ per square foot of roof area that is planted with vegetation, or approximately $25 \%$ of the typical costs associated with the materials, labor, installation, and design of the green roof. Building owners can apply for the credit starting January 1 , 2009, under the pilot program that will expire after March 15, 2013, unless it is extended.

It is estimated that each 10,000-square-foot green roof, for instance, can capture between 6,000 and 12,000 gallons of water in each storm event, the evaporation of which will produce the equivalent of between 1,000 and 2,000 tons of air conditioning - enough heat removal to noticeably cool 10 acres of the city.

Green roofs are taking root in other areas, too. According to the Cable News Network, the green roof industry in Germany is now worth $\$ 77$ million annually. Germany has instituted the Green Area and Biotope Area Federal Law. Green roofs are not a legal requirement, but through incentives set up at a city level, the mandates have helped to encourage lower prices.

\subsubsection{Example: Municipal Incentives and Regulations}

Under PlaNYC adopted in 2007, New York City set a goal of achieving a 30\% reduction in the city's annual greenhouse gas emissions below 2005 levels by 2030. Recognizing that nearly $80 \%$ of citywide emissions result from the energy used in buildings, the Greener, Greater Buildings Plan, passed in late 2009, is a comprehensive framework that requires ongoing efficiency improvements in existing large buildings. The plan has six complementary components that use a series of mandates, challenges, and incentives to reduce demand among the city's largest energy consumers:

1. more stringent requirements in the New York City energy code

2. lighting upgrades and submetering

3. benchmarking

4. audits and retrofits

5. green workforce development training

6. green building financing.

As part of the program, the city is developing a revolving loan fund that will be provided at no cost to New York City taxpayers. The city will use \$16 million in federal stimulus funding allocated to the city under the EECBG program for this direct lending program. Originally, the city had planned on leveraging the PACE model to facilitate this program. With the challenges that are facing PACE programs, New York City is now said to be considering other options.

\subsubsection{Example: Building Star - Tax Credits and Accelerated Depreciation}

The Real Estate Roundtable and the Building Owners and Managers Association, along with Rebuilding America, have proposed an incentive-based solution called Building Star. As proposed, Building Star (introduced in the U.S. Congress as "The Building Star Energy Efficiency Act of 2010," S. $3079, \mathrm{HR} 5476^{1}$ ) is a federal rebate program for energy efficiency investments (including equipment,

\footnotetext{
${ }^{1}$ http://www.govtrack.us/congress/bill.xpd?bill=s111-3079 (accessed February 2011).
} 
materials, and services). The legislation also would create a loan program to make grants to states that would allow them to extend low-interest loans to property owners to finance the remaining portion of their energy efficiency investments. It is unclear at this point whether or not this bill will make it out of Congress.

Other tax-related options supported by the real estate industry include an energy efficiency tax deduction up to as much as $\$ 3.00$ per square foot as well as accelerated depreciation tied to environmental performance measures.

\subsubsection{Energy Performance Certificates and Display Energy Certificates}

Energy performance certificates (EPCs) became compulsory on all commercial properties constructed, rented, or sold within the UK effective October 1, 2008. With the introduction of EPCs into the commercial sector, details of the energy efficiency and environmental impact of a rental property will need to be made available to prospective tenants/buyers at the earliest opportunity. The energy certificate provides a rating of the energy efficiency and carbon emissions of a building from $A$ to $G$, where $A$ is very efficient and $\mathrm{G}$ is very inefficient. For rental property, an EPC is currently valid for 10 years and can be reused as many times as required within that period. Landlords do not have to commission a new EPC each time a new tenancy starts, but they are required to provide a copy of the latest EPC to new tenants. Furthermore, although landlords are not obliged to make any of the changes suggested on the EPC, measures that could be taken to improve the property's energy efficiency and environmental impact rating are highlighted. Public authorities with space greater than 1,000 square meters (10,764 square feet) must display a valid EPC.

As of December 2007, all single-family homes in the UK and Wales require an energy rating before they can be sold. Energy Performance Certificates are included in the Home Information Pack, which rates the home from A to $\mathrm{G}$ and lists efficiency measures the homeowner can take.

Energy performance certificates would create transparency and impact valuation by creating a protocol, metrics, and public accounting of performance. Linked with energy performance certificates are display energy certificates (DECs). The DECs show up to 3 years of data on energy used in the building. They must be provided by an accredited assessor (appraiser) and must be displayed on the building.

There have been some suggestions by the Brookings Institution to incorporate energy usage reporting into Real Estate Settlement Procedures Act (RESPA) statements upon property sales. Although RESPA does not apply to commercial properties, a change of this nature to the residential sector would likely set the stage for this type of reporting to apply more broadly. Presumably, the form would be similar to that of energy performance certificates in the European Union.

\subsubsection{Carbon Trading}

As to carbon trading, the most action seems to be at the power plant level, with some focus on transportation and a few other sectors. Many feel that a hard cap on carbon is necessary along with some combination of auction and allocation of permits. Given existing efforts outside the United States, a national and international agreement would be useful. There seems to be substantial agreement that, 
although many of the specific financial mechanisms would be helpful in increasing investment in energy efficiency, they will be insufficient until there is a game-changing limitation on carbon usage.

In the United States, regional greenhouse gas initiatives are moving forward. The Northeast Regional Greenhouse Gas Initiative (RGGI) ${ }^{1}$ began emissions trading on September 25, 2008. Incorporating 10 northeastern states, the power companies submitted sealed bids to buy allowances to emit greenhouse gasses. The RGGI requires a 10\% reduction in emissions by 2019 by power plants only. This program requires $100 \%$ of the allowances to be auctioned. In the West, seven U.S. states and four Canadian provinces are part of the Western Climate Initiative. ${ }^{2}$ This initiative, which is scheduled to start in 2012, requires power plants and industries to cut total emissions by $15 \%$ by 2020 . In 2015 , the program will expand to cover emissions from transportation, residential, and commercial fuel use. Plans recently started in the Midwest for a third program that will include six more states and one province. Overall, 24 states and 5 provinces are working on cap and trade programs.

Both voluntary and mandatory trading schemes are targeted upstream at the utilities and major industrial users. The mechanisms have not been engineered to deal effectively with downstream users such as building owners and tenants. They are still to be seen in practicality, but baseline data and the development of a protocol to capture, verify, and monitor the data may support applicability of carbon trading in the real estate sector.

To qualify in the certified emissions reduction (CER) market, a project must prove its "additionality." Under the Clean Development Mechanism (CDM), industrialized nations can partly meet their Kyoto Protocol emission reduction targets by financing low-carbon initiatives in developing countries and buying carbon credits from those projects. However, for these emission projects to qualify to sell carbon credits, they have to demonstrate that they are "additional" and would not have gone ahead without assurances that they could generate a revenue stream by selling carbon credits. If taken to its logical conclusion, this poses a problem for many projects in the real estate industry because of the lack of benchmarking and the fact that an energy efficiency project by nature accrues benefits to the owner in the form of lower operating expenses. It is possible that under the basis of a lease, which allocates efficiency benefits to the tenant, the owner might be able to claim additionality, but this is far from clear.

The questions that need to be answered relative to buildings are How would you baseline energy usage? How much efficiency, over what time period, would be necessary? How much additional value and/or risk reduction would such a scheme add to the building, and how would you assess such value? What is the level of magnitude of potential benefit? How much would it cost to implement? Who could participate-would it be international, national, regional, state?

Voluntary carbon trading seems to have more potential for downstream users such as building owners. However, this is also an unproven market. ProLogis, one of the largest real estate owners in the United States and globally, is the first real estate firm participating on the Chicago Climate Exchange (CCX). As a corporate entity, ProLogis commits to reducing its own carbon footprint by $6 \%$ below its baseline. As an associate member, ProLogis annually calculates and offsets $100 \%$ of its carbon footprint from office operations and business travel globally.

\footnotetext{
${ }^{1} \mathrm{http}: / /$ www.rggi.org/home.

${ }^{2}$ Western Climate Initiative - Program Design: http://westernclimateinitiative.org/the-wci-cap-and-tradeprogram/program-design.
} 
ProLogis has instituted a company-wide initiative that includes a "champion" in each office, monthly calls to work on creative ways to save energy, competitions, and ongoing training for the 1,500 international staff members. The corporation also has committed to LEED for all new construction. ProLogis held discussions with CCX to design a protocol for baselining and measuring energy usage and efficiency improvements for its existing building stock, although nothing public ever was released. The goal is that these savings could be measured, monitored and verified, and ultimately traded on the exchange.

\subsubsection{Efficient Building Trading Scheme}

An idea proposed by property company Lend Lease Corporation of Australia is that of an Efficient Building Scheme, ${ }^{1,2}$ similar to an emissions trading scheme except that it recognizes energy efficiency improvements in nonresidential buildings (e.g., office, industrial, hospital, school, retail, hospitality) rather than emissions avoided. It would treat 1 ton of greenhouse gas emissions $\left(\mathrm{tCO}_{2} \mathrm{e}\right)$ avoided in the same way that a conventional emissions trading scheme treats 1 ton of $\mathrm{CO}_{2} \mathrm{e}$ that is not emitted due to a change in energy generation. Building owners would provide data on their buildings' greenhouse gas emissions, including

- energy consumption (electricity and gas bills, including any on-site energy generation)

- building type (e.g., office, hotel, retail, school)

- location (climatic zone and/or economic center).

From these data, the building's energy intensity (kilowatt-hours per square meter per year) and carbon intensity (tonnes of equivalent carbon dioxide per square meter per year using official greenhouse gas emission coefficients for fuel sources) would be calculated. For industry players who improve the energy efficiency of their buildings there would be a financial return. The Efficient Building Scheme would provide a carrot and a stick, balancing permit allocation with an obligation to acquire permits. A cap would be applied to carbon emissions from buildings, and those that achieve lower emissions than the cap could sell the surplus to less efficient buildings. Trading of the permits would be fungible between the emissions permits and energy efficiency permits. A government body would set (presumably, based on regional and climatic variances) separate trajectories for energy efficiency for each building class (i.e., office buildings, schools, hospitals). To provide certainty for the industry, it is projected that each trajectory be set for a minimum 10-year period and ideally longer. The first year of trading might be based on the average energy efficiency of each building class, with future years set as aggressively as needed or wanted, according to national targets.

\footnotetext{
${ }^{1}$ Bovis LendLease Sustainability - "Efficient Building Scheme" http://www.bovislendlease.com/sustainability/pdf/EfficientBuildingScheme.pdf The Efficient Non-Residential Building Scheme Bill was introduced and rejected by the Australian Senate in late 2009. Legislators who brought the bill to a vote indicate they will propose it again.

${ }^{2}$ The use of the term "scheme" here is consistent with the language used to describe the Energy Trading Scheme in Europe.
} 
This concept addresses some of the most challenging issues related to adoption of energy efficiency strategies:

- principal/agent issue - It moves the point of obligation to the building owner, so that obligation is aligned with ownership, opportunity and operation, and it can also apply to buildings without a capital investment

- cost - It creates a low cost of transaction, allowing for universal application and annual auditing for robustness

- measurement, verification, and valuation - It provides reliable benchmarks/trajectories into the future, providing investment certainty, allowing for assets and liabilities to inform valuations, and providing an ability to balance against deferred infrastructure investment.

\subsubsection{Carbon Offsets}

Carbon offsets are applicable to multifamily and affordable housing as well as commercial buildings.

\subsubsection{Example: Green Communities Offset Fund}

Enterprise Community Partners, a national nonprofit, raises charitable contributions from organizations, individuals, and events to purchase carbon offsets from developers of green affordable housing projects. Fully $100 \%$ of all contributions to the Green Communities Offset Fund ${ }^{1}$ go to community-based groups for activities that reduce energy use and global warming pollution in homes for low-income people and result in verified carbon emissions reductions. All fund proceeds support activities that directly reduce carbon emissions below the level that otherwise would be achievable.

Contributors to the fund receive credit for verified emissions reductions that can offset their own carbon generating activities and may take a tax deduction for their contribution. The fund employs rigorous measurement and verification procedures to determine and certify offsets that are aligned with international best practices. The fund "retires" the verified emission reductions it purchases, meaning the reductions cannot be bought or sold during the period of the fund's purchase.

\footnotetext{
${ }^{1} \mathrm{http}: / /$ www.greencommunitiesonline.org/green/offset/; http://www.greencommunitiesonline.org/projects/projects_by_name.asp.
} 


\section{State Energy Efficiency Policies}

According to Hendricks et al. (2010), 10 key energy efficiency policies that states are adopting or experimenting with to varying degrees are

- energy efficiency measures in Renewable Portfolio Standards - policies that not only require utility companies to meet a set portion of demand from renewable energy but also include energy efficiency as a qualifying form of clean energy

- energy efficiency measures in Renewable Energy Credits - policies that establish markets for tradable clean energy credits and include energy efficiency as a qualifying clean energy resource

- energy efficiency specific standards that require utilities to plan for meeting a percentage of future growth in demand through energy efficiency instead of increasing supply - These policy tools include Energy Efficiency Resource Standards and Energy Efficiency Portfolio Standards.

- unbundled utility structures in which energy transmission and distribution utilities are separate from power generation companies that own power plants, encouraging least-cost strategies for meeting energy demand through conservation

- decoupled utility rate structures, where utilities' rates are adjusted to compensate for changes in the volume of energy sold, removing the structural disincentive to conserve energy

- aligning efficiency with utility companies' shareholder benefits, such as bonus rates of return, reimbursing program costs, or other incentives that help transform efficiency from a special program into a core business practice

- penalties for noncompliance with energy efficiency standards, to ensure that well-intentioned programs are effectively implemented, monitored, and improved upon over time - Effective policies must have real consequences.

- regulatory cost-benefit tests that focus on utilities' real costs, in order to isolate the specific value offered by energy efficiency investments.

- property-assessed financing structures that link the benefits of installed efficiency to a building, rather than the owner of the building, allowing repayment of financed investments to transfer automatically to new owners.

- service assessment delivery structures, which allow government jurisdictions to directly facilitate financing of upfront capital costs, assuring repayment through municipal or other service assessment mechanisms.

The following 10 states have leading efficiency policies and programs (Hendricks et al. 2010):

$\begin{array}{ll}\text { Connecticut } & \text { New York } \\ \text { California } & \text { Texas } \\ \text { Maryland } & \text { North Carolina } \\ \text { Massachusetts } & \text { New Jersey } \\ \text { Pennsylvania } & \text { Ohio }\end{array}$




\subsection{Discussion}

\subsection{Insights from the Analysis}

Based on the available technology and the sheer amount of information on hand actual investment in high-performance building lags behind what would be expected. In an environment where concepts such as green, sustainable, and high-performance seem to be in the forefront, why are more property owners and investors not taking note and acting?

The perceived market risks of doing energy efficiency are greater than any potential benefits. Many in the commercial building sector believe there is a significant cost premium associated with the design and construction of high-performance buildings, deep efficiency is difficult to attain, retrofits are disruptive to occupants and cost premiums are not recovered when the buildings are sold or leased.

Selected findings from the analysis completed include the following:

- Current technology is capable of delivering substantial efficiency. However, technology alone cannot solve the problem.

- While there is an increasing level of consciousness around energy efficiency, this does not reflect a concrete commitment to actual investment in, or implementation of, efficiency or highperformance measures.

- The equipment must be purchased, installed, and properly run for efficiency to be realized.

- Deployment is accelerated with the right mix of financial tools.

- Direct funding for efficiency retrofits is neither sustainable nor scaleable; tactics must leverage a range of options.

- Deployment must incorporate a multidisciplinary approach and collectively address the issues of finance, investment and incentives; metrics and verification; operations and maintenance; awareness, education, and training; design and construction; and the energy and utility landscape.

- For real estate investors, owners, and financiers, traditional bottom-line factors such as revenue, expenses, risk, and return, lead investment analysis and decision-making rather than the narrower lifecycle cost analysis (LCCA).

- Real estate investment decisions are multi-faceted and complex. Different owner strata have differing motivations. Decisions involve numerous stakeholders with often competing, and complimentary objectives. To be successful, solutions and messaging must directly address value and bottom line results.

- Value considerations are important in framing the message.

$\circ$ Broadly speaking, the industry judges the market risks associated with high-performance attributes to be greater than potential benefits. In part, this is based in reality, and in part due to cultural barriers, business norms, and competing stakeholder interests.

- The perception of value depends on the stakeholders, investment objectives, access to and cost of capital, property type, and lease structure. 
- To monetize energy savings, the savings must be bankable. To be bankable, the investment community must believe the efficiency is meaningful and will be persistent over time, or else they will not invest in or finance the improvements.

- Monitoring and verification, ongoing commissioning, and robust maintenance are critical. Through metering and response, they provide transparency and enable persistent efficiency, increasing stability and continuity and reducing uncertainty over time.

- There is a need to create partnerships between seemingly disparate groups, some with competing agendas and differing financial and regulatory incentives. This includes engaging the regulated utility market and addressing inherent complexities that serve to dampen rather than promote investment in efficiency.

- To forge common understanding and shared objectives, language needs to be broadened to incorporate financial and energy metrics in the same medium; for example, cost per kilowatt-hour needs to be translated easily to cost per square foot.

Financing remains a critical component in deploying the necessary technology and is a significant hurdle to seeing substantial investment in high-performance attributes. Hurdles can be pivotal and include a lack of data, first cost, capital versus operating budgets, risk exposure, the low ratio of energy costs to total operating expenses, high transaction costs, discount factor issues, and the inadequacy of traditional financing mechanisms for energy efficiency projects.

Several new and reformulated ideas are emerging to facilitate the movement of investment capital to the sector. The most promising of these financing structures aim to monetize energy efficiency, identify new types of collateral and means of ensuring repayment, and extend financing terms to address long payback periods. For commercial property, they include

- On-bill financing (OBF) - A utility company (or some other entity) finances the energy efficiency improvements. The property owner receives the benefit of the efficiency reduction in the form of a partial reduction in his monthly utility with the balance between the actual savings and the rate payment used to amortize the improvements plus interest. The obligation runs with the property, is attached to the utility bill, and would be passed along to subsequent purchasers.

- Energy and efficiency services agreements (ESAs) - An ESA requires no up-front capital from the commercial property owner; third-party financing cover all project costs. The provider initiates and maintains the contractual relationship with the efficiency retrofit contractor and handles ongoing management of the systems. The client continues to pay the energy bill plus an energy services payment to the provider, who takes a fee for managing the process and repays the debt and equity. The combined net payment is intended to be equal to or less than the pre-retrofit energy cost.

- property-assessed clean energy (PACE) - A municipality loans money to owners to make improvements to their property. To secure the loan, a lien is placed on the property in the form of an additional property tax assessment. Liens are repaid via an add-on to the property tax bill at an established rate of interest over a specific period, generally 20 years. The lien remains with the property, even upon sale, until fully repaid. The lien sits in priority to the property's first mortgage.

A concerted approach to facilitating these mechanisms is necessary and one in which DOE could take a role. The key findings indicate that there is no single response that will meet all needs, there are 
significant barriers and competing interests, public/private partnerships add value, the solutions must be contextual, a value must be put on energy usage, and government has a significant role to play.

\subsection{Suggested Path Forward}

To support and encourage investment in and deployment of high-performance measures in all building classes, both quickly and at scale, DOE needs to engage real estate professionals on the basis of financial returns over the holding period of the property and include a wide variety of inputs beyond energy or resource cost. The following criteria must be addressed:

- value proposition that articulates the link between efficiency and returns

- leadership modeled and best practices publicized

- clear action steps that set the framework for success

- transparency and certainty around energy use and efficiency performance

- persistence of high-performance measures over time

- education/training tailored for key stakeholders such as occupants, operators, and investors

- investment/financing which values high-performance and efficiency as a bankable asset

- ease and simplicity of solutions that make adoption of high-performance measures effortless.

Many of these needs identified (Table 10.1) can be addressed effectively by DOE alone, or in partnership to promote investments in high-performance buildings. Needs-driven promotion efforts include

- Facilitate (and publicize) pilot projects between property owners, utilities, and financing sources.

- Develop a set of consistent, agreed-upon standardized metrics and valuation methodology so that properties can be evaluated across the sector allowing for comparison between assets and enhancing uniform lending and investment strategies.

- Develop a prototype "energy usage sticker" to provide a visible indicator of usage and thereby impacting tenant and occupant interest in building performance and demand for high-performance buildings. The sticker should take into consideration varying occupancy conditions, weather variations, and energy price differences, making the information specific to region and property type. Information provided would directly correlate the energy usage to the cost over time (e.g., 5 years).

- Partner with industry organizations to present tailored and targeted training for major stakeholder groups, such as the Building Owners and Managers Association, Urban Land.

- Institute, Institute of Real Estate Managers, National Association of State Energy Officials, and the American Bankers Association.

- Develop databases to collect and disseminate meaningful performance and valuation data on highperformance buildings, allowing real estate professionals to compare properties more effectively and ultimately allowing for data to be standardized, risk analyzed, and financial market mechanisms crafted. 
Table 10.1. Identified needs

\begin{tabular}{|c|c|}
\hline Criterion & Solution \\
\hline $\begin{array}{l}\text { Value } \\
\text { proposition }\end{array}$ & $\begin{array}{l}\text { Tie to risk/return } \\
\text { Tie to health and safety (which leads to improved building performance and reduced risk) }\end{array}$ \\
\hline Leadership & $\begin{array}{l}\text { Publicize successes and failures to generate best-practices summary } \\
\text { Provide energy usage sticker for government buildings } \\
\text { Expand the Global Superior Energy Performance Partnership } \\
\text { Model construction and retrofit of high-performance buildings } \\
\text { Provide technical assistance }\end{array}$ \\
\hline $\begin{array}{l}\text { Clear action } \\
\text { steps }\end{array}$ & $\begin{array}{l}\text { Step-by-step decision-making tool box, addressing impact of key performance attributes on risk } \\
\text { and return } \\
\text { - Road map that outlines discrete path for the investment decision process - including short } \\
\text { and long term outcomes } \\
\text { - Easily replicable and customizable by property type and specific property } \\
\text { Quick wins } \\
\text { - Facilitate pilot projects - engage property owners and lenders around a real building, a real } \\
\text { project, with real leases and real tenants. } \\
\text { - Develop model lease language in partnership with Commercial Real Estate Energy Alliance } \\
\text { members. }\end{array}$ \\
\hline $\begin{array}{l}\text { Transparency/ } \\
\text { certainty }\end{array}$ & $\begin{array}{l}\text { Standardized baseline and metrics } \\
\text { Dashboard } \\
\text { Energy performance disclosure; e.g., energy usage sticker (akin to fuel mileage sticker) } \\
\text { Standardized underwriting }{ }^{(a)} \\
\text { Social networking postings } \\
\text { Competitions }\end{array}$ \\
\hline Persistence & $\begin{array}{l}\text { Measurement and verification-metering, real time monitoring } \\
\text { Robust operations and maintenance- ongoing commissioning, active and immediate tuning and } \\
\text { correction of identified problems. }\end{array}$ \\
\hline $\begin{array}{l}\text { Education/ } \\
\text { training }\end{array}$ & $\begin{array}{l}\text { Detailed summary of finance/investment options that address key points for each: } \\
\text { - Description, applicability, availability, maturity, terms and limits, benefits, and hurdles. } \\
\text { - Capacity building of service providers, municipalities, real estate professionals } \\
\text { - Partner with key stakeholder organizations to provide education and training: } \\
\text { - Building Owners and Managers Association, Urban Land Institute, National Association of } \\
\text { Realtors, International Council of Shopping Centers, National Association of State Energy } \\
\text { Officials, American Bankers Association, etc. } \\
\text { - Webinars, presentations to property owners, investors, realtors, energy officials, financiers, } \\
\text { rating agencies, and municipalities through industry meetings, conventions, trainings, events } \\
\text { and on-line presence. }\end{array}$ \\
\hline $\begin{array}{l}\text { Investment/ } \\
\text { Financing }\end{array}$ & $\begin{array}{l}\text { On-bill pay } \\
\text { Energy-efficiency services agreement } \\
\text { property-assessed clean energy (PACE) } \\
\text { - modified to incorporate greater transparency of performance metrics } \\
\text { Climate benefit districts } \\
\text { Incentives/rebates to supplement and leverage internal cash and financing options. }\end{array}$ \\
\hline Ease & $\begin{array}{l}\text { "One-stop" providers, including financing, approved (and trained) contractors, performance } \\
\text { guarantee, real-time monitoring, verification and maintenance. }\end{array}$ \\
\hline
\end{tabular}

(a) Lawrence Berkeley National Laboratory is currently working on a project that aims to develop a commercial mortgage underwriting protocol and a tool that evaluates energy use volatility. 
- Work with the Commercial Building Energy Alliances to craft lease language that better aligns property owner and tenant incentives for efficient resource utilization.

- Provide capacity building grants to help utilities and municipalities develop the core competencies necessary to deliver the program along with a protocol for roll-out of such a program. ${ }^{1}$

- Evaluate the correlation between the default rate on property mortgages and incremental increases in energy prices, to enable investors, owners, financiers, and tenants to evaluate the potential for risk reduction associated with persistent high-efficiency performance.

\footnotetext{
${ }^{1}$ Among a handful of other states, California, for example, has a wide variety of programs and protocols currently in
} existence and planning that could be leveraged and modified for wider dissemination nationally. 


\subsection{Conclusion}

The DOE Building Technologies Program can act as a catalyst to deploy energy efficiency and highperformance buildings. While we have the technology to achieve increased efficiency, without tying efficiency and high performance to the real risk, return, and value impact, property owners will not take meaningful action. We have to speak the real estate industry's language and address their financial concerns in order to be successful. Language and messaging must tie directly to the overall investment analysis, not just life-cycle cost. It is necessary to recognize and address the unique and often complex and competing interests of the stakeholders. Reducing the uncertainty around energy savings is critical. The investment community must believe the efficiency is both meaningful and persistent over time in order to finance and invest in improvements. Support from DOE in setting baselines and metrics, as well as encouraging best practices for measurement, verification, and monitoring, will reduce the perceived risk and help provide a means for defining the value of high-performance attributes. 


\subsection{Literature Cited}

American Recovery and Reinvestment Act of 2009. 2009. Public Law 111-5, as amended, 26 USC 1 et seq.

ANSI/ASHRAE/USGBC/IES Standard 189.1-2009. Standard for the Design of High-Performance Green Buildings Except Low-Rise Residential Buildings. American Society of Heating, Refrigerating and Air-Conditioning Engineers, Inc., Atlanta, Georgia.

Attari SZ, ML DeKay, CI Davidson, and W Bruin de Bruin. 2010. "Public perceptions of energy consumption and savings." Proceedings of the National Academy of Sciences. PNAS direct submission; available through the PNAS open access option at http:/www.pnas.org/cgi/doi/10.1073/

pnas.1001509107 (September 2010).

Dembo R. 2009. “Let's Do For Buildings What We Have Done For Cars.” Zerofootprint Foundation, Toronto, Ontario, Canada. Available from http://www.zerofootprintfoundation.org/images/uploads/ Lets_Do_For_Buildings_What_We_Have_Done_For_Cars_US.pdf (September 2010).

Eastern Research Group, InnoVest Group, et al. 2003. "Estimating the Value of Participation in EPA's Energy Star Program." Presented at the United Nations Environment Programme-Principles for Responsible Investment (UNEP-PRI) webinar, January 2009.

EIA. 2006. “2003 CBECS Detailed Tables. Building Characteristics Tables for All Buildings (Including Malls), table A1.” Energy Information Administration, U.S. Department of Energy, Washington, D.C. Available from http:/www.eia.doe.gov/emeu/cbecs/cbecs2003/detailed_tables_2003/ detailed_tables_2003.html (September 2010).

EIA. 2009. “Annual Energy Outlook 2010 - Early Release Overview.” U.S. Energy Information Administration, U.S. Department of Energy, Washington, D.C. Available from www.eia.doe.gov/oiaf/aeo/pdf/overview.pdf (September 2010).

Emergency Planning and Community Right-to-Know Act. 1986. Public Law 99-499, as amended, 42 USC 11001 et seq.

FOMC. 2010a. "Minutes of the Federal Open Market Committee - June 22-23, 2010." Board of Governors of the Federal Reserve System. Available from http://www.federalreserve.gov/ monetarypolicy/fomcminutes20100623.htm (September 2010).

FOMC. 2010b. "Minutes of the Federal Open Market Committee - August 10, 2010." Board of Governors of the Federal Reserve System. Available from http://www.federalreserve.gov/monetarypolicy/fomcminutes20100810.htm (September 2010).

GAO. 2005. Energy Savings - Performance Contracts Offer Benefits, But Vigilance Is Needed to Protect Government Interests. GAO-05-340. U.S. Government Accountability Office, Washington, D.C. Available from http://www.gao.gov/products/GAO-05-340 (September 2010). 
Gladwell M. 2002. The Tipping Point: How Little Things Can Make a Big Difference. Back Bay Books, Hatchette Book Group, Boston, Massachusetts.

Granade HC, J Creyts, A Derkach, P Farese, S Nyquist, and K Ostrowski. 2009. Unlocking Energy Efficiency in the U.S. Economy. McKinsey \& Company, New York.

Hamilton JT. 2005. Regulation through Revelation: The Origin, Politics, and Impacts of the Toxics Release Inventory Program. Cambridge University Press, New York.

Hawken P, A Lovins, and LH Lovins. 2008. Natural Capitalism: Creating the Next Industrial Revolution. Back Bay Books, Hatchette Book Group, Boston, Massachusetts. Chapter 6 available from http://www.natcap.org/images/other/NCchapter6.pdf (February 2011).

Hendricks B, B Campbell, and P Goodale. 2010. Efficiency Works - Creating Good Jobs and New Markets Through Energy Efficiency. Energy Resource Management Corporation, Southfield, Michigan. Available from http://www.americanprogress.org/issues/2010/08/pdf/good_jobs_new_markets.pdf (September 2010).

Hopper N, C Goldman, D Gilligan, TE Singer, and D Birr. 2007. A Survey of the U.S. ESCO Industry: Market Growth and Development from 2000 to 2006. LBNL-62679, Lawrence Berkeley National Laboratory, Berkeley, California.

IPD. 2008. IPD Environment Code -- Measuring the Environmental Performance of Buildings. Investment Property Databank Limited, London, United Kingdom. Available from http://www.ipdoccupiers.com/Default.aspx?TabId=1632 (September 2010).

ISO. 2010. "Future ISO 50001 on energy management progresses to Draft International Standard." International Organization for Standardization, Geneva, Switzerland. Available at http://www.iso.org/iso/pressrelease.htm?refid=Ref1337 (September 2010).

Johnson Controls. 2010a. "2010 Energy Efficiency Indicator - Global Results.” Institute for Building Efficiency, Johnson Controls, Inc., Milwaukee, Wisconsin. Available from http://www.institutebe.com/Whats-New/global-energy-efficiency-indicator-results.aspx (September 2010).

Johnson Controls. 2010b. "2010 Energy Efficiency Indicator Results for North America." Institute for Building Efficiency, Johnson Controls, Inc., Milwaukee, Wisconsin. Available from http://www.institutebe.com/Whats-New/north-america-energy-efficiency-indicator.aspx (September 2010).

KEMA. 2006. Packaged Commercial HVAC Equipment Market Characterization. Northeast Energy Efficiency Partnerships, Inc., Lexington, Massachusetts.

Kibert CJ. 2007. Sustainable Construction: Green Building Design and Delivery. 2nd edition. John Wiley \& Sons, Inc., Indianapolis, Indiana. 
Kok N, P Eichholz, and J Quigley. 2009. "Doing Well by Doing Good? Green Office Buildings.” Center for the Study of Energy Markets, University of California Energy Institute, UC Berkeley, California. Available from http://escholarship.org/uc/item/4bf4j0gw (September 2010).

Lutzenhiser L, NW Biggart, R Kunkle, TD Beamish, and T Burr. 2001. Market Structure and Energy Efficiency: The Case of New Commercial Buildings. Institute for Energy Efficiency, College of Engineering, UC Santa Barbara, California (formerly the California Institute for Energy Efficiency).

McKinsey \& Co. 2009. Pathways to a Low-Carbon Economy - Version 2 of the Global Greenhouse Gas Abatement Cost Curve. McKinsey \& Company, New York. Available from www.mckinsey.com/clientservice/ccsi/pathways_low_carbon_economy.asp (September 2010).

Muldavin SR. 2010. Value Beyond Cost Savings: How to Underwrite Sustainable Properties. Green Building Finance Consortium, The Muldavin Company, Inc., San Rafael, California. Available from http://www.greenbuildingfc.com/ (September 2010).

NREL. 2009. Decoupling Policies: Options to Encourage Energy Efficiency Policies for Utilities. NREL/BR-6A2-46606, National Renewable Energy Laboratory, Golden, Colorado. Available from http://www.nrel.gov/docs/fy10osti/46606.pdf (September 2010).

Pivo G and J Fischer. 2009. "Investment Returns from Responsible Property Investments: Energy Efficient, Transit Oriented and Urban Regeneration Office Properties in the US from 1998-2008."

ProLogis. 2010. "Prologis Renewable Energy Announces New Rooftop Solar Project Totaling 11.1 MW. New Project Increases ProLogis’ Renewable Energy Portfolio to 24.6 MW Globally.” Press Release, May 10, 2010, ProLogis, Denver, Colorado. Available from http://ir.prologis.com/releases.cfm (September 2010).

Real Estate Settlement Procedures Act. 1974. 12 USC 27, Sections 2601-2617.

Risser R and L Wood. 2009. Making the Business of Energy Efficiency Both Scalable and Sustainable. Policy Brief 09-01, The Brookings Institution, Washington, D.C. Available from http://www.brookings.edu/papers/2009/04_energy_efficiency_wood.aspx (September 2010).

Rogers EM. 2003. Diffusion of Innovations. 5th edition. Free Press, Simon \& Schuster, New York.

Sinek S. 2009. Start with Why: How Great Leaders Inspire Everyone to Take Action. Portfolio Hardcover, Penguin Group (USA), New York.

Thaler RH and CR Sunstein. 2008. Nudge-Improving Decisions About Health, Wealth and Happiness. Yale University Press, New Haven, Connecticut.

Troianovski A. 2010. “Office Vacancy Rate Keeps Climbing.” The Wall Street Journal, July 6, 2010. Available from http://online.wsj.com/article/SB10001424052748703778504575347190869129432.html (September 2010). 
WBCSD. 2009. Energy Efficiency in Buildings - Transforming the Market. World Business Council for Sustainable Development. Available from http://www.wbcsd.org/Plugins/DocSearch/ details.asp?DocTypeId=251\&ObjectId=Mzc5NDk (September 2010). 


\section{Appendix A}

\section{Commercial Buildings Integration Multi-Year Program Plan FY 2010-2015 Opportunities and Gaps Excerpt on Financing}




\section{Appendix A}

\section{Commercial Buildings Integration Multi-Year Program Plan FY 2010-2015 Opportunities and Gaps Excerpt on Financing}

Many in the commercial building development and design communities feel that there is a significant cost premium associated with the design and construction of high-performance buildings. Further, they believe these cost premiums are not recovered when the buildings are sold and or leased after the completion of construction. These perceptions discourage developers from designing and building highperformance buildings, as observed in a report completed for the California Institute for Energy Efficiency:

So what does all this mean for energy efficiency in new commercial office buildings? Given what we have learned about building markets and the nature of building industry interests, it is clear that increasing the energy efficiency of buildings is of little value to the building industry. In terms of the parameters important to the building industry, buildings are energy efficient. There is really no value to the building industry in making buildings more energy efficient - it is risky. The perceived market risks of doing energy efficiency are much greater than any potential benefits. ${ }^{1}$

There are two gaps associated with financing. The first gap is the need for field data that allow for comparisons of cost differentials, if any, associated with the design and construction of high-performance buildings. The absence of this data will discourage widespread investments in high-performance buildings across the development community as these investments are not seen as financially rewarding. The second gap is the need to identify financing methods for new and retrofit commercial buildings that address the recovery of increased investment costs and even provide incentives to design for highperformance. One approach might be the establishment of a bank fund having the authority to offer direct loans, loan guarantees, and insurance products to high-performance technology and building developers. A sample approach, the Clean Energy Investment Bank Fund, was proposed in the Clean Energy Investment Bank Act of 2008 (Senate Bill 2730). ${ }^{2}$

Commercial Buildings funded 2010 actions addressing whole-building, life-cycle opportunities and gaps are:

- Analysis in Support of CBI Decision-Making on Financing of High-Performance Buildings - This study will work to identify the true costs of high-performance buildings relative to other buildings, address the overall commercial building value of high-performance buildings and the messages needed to develop a consensus to design and build high-performance buildings. [PNNL]

\footnotetext{
${ }^{1}$ Lutzenhiser L, NW Biggart, R Kunkle, TD Beamish, and T Burr. 2001. Market Structure and Energy Efficiency: The Case of New Commercial Buildings. Institute for Energy Efficiency, College of Engineering, UC Santa Barbara, California (formerly the California Institute for Energy Efficiency).

${ }^{2} \mathrm{http}: / /$ www.govtrack.us/congress/bill.xpd?bill=s110-2730\&tab=summary (September 2010).
} 
- Cross-Cutting Analysis of Financing Alternatives - Analysis to identify the most promising financing alternatives for commercial building new construction and retrofits will be sponsored by the BTP. Navigant will serve as the lead for this analysis with participation from all the National Laboratory Collaborative on Building Technologies member laboratories. Outcome will be a R\&D plan covering the range of financing needs and alternatives.

The remaining identified unaddressed financing need is to explore the potential for a Clean Energy Investment Bank Fund or other financing arrangement for commercial buildings construction and/or renovation. 


\section{Appendix B}

\section{High-Performance Buildings - Literature Reviewed}




\section{Appendix B}

\section{High-Performance Buildings - Literature Reviewed}

\section{B.1 Energy Efficiency Impact on Value and Returns}

Bernstein HM. 2006. Green Building SmartMarket Report 2006. McGraw Hill Construction, Bedford, Massachusetts. Available from http://construction.com/SmartMarket/greenbuilding/default.asp (September 2010).

Bowles E and Rocky Mountain Institute. 2007. The Energy Challenge: A New Agenda for Corporate Real Estate. CoreNet Global and Rocky Mountain Institute, Atlanta, Georgia, and Boulder, Colorado. Available from

http://www.energy.ca.gov/greenbuilding/ab2160/documents/resource_docs/Energy_Challenge_CoreNet_ RMI_2007.pdf(September 2010).

Building Design+Construction, Editors. 2006. "Green Buildings and the Bottom Line." White paper. Building Design+Construction. Available from http://www.bdcnetwork.com/article/380760-

BD_C_White_Paper_2006_Green_Buildings_and_the_Bottom_Line.php (September 2010).

Center for Neighborhood Technology (CNT). 2009. Regional Green Building Case Study Project: A Post-Occupancy Study of LEED Projects in Illinois. U.S. Green Building Council - Chicago Chapter, Chicago, Illinois. Available from http://www.cnt.org/repository/Regional-Green-Building-CaseStudy.pdf (September 2010).

Chappell TW and C Corps. 2009. High Performance Green Building: What's It Worth? Investigating the Market Value of High Performance Green Buildings. Cascadia Region Green Building Council, Vancouver Valuation Accord, and Cushman \& Wakefield, Seattle, Washington, and Vancouver, British Columbia, Canada. Available from http://www.cascadiagbc.org/news/GBValueStudy.pdf (September 2010).

Chappell TW. "Sustainability Today - Where are we now and Where do we go from here?" 2009.

Research publication for The Steven L. Newman Real Estate Institute at CUNY, New York, New York. Available from http://www.baruch.cuny.edu/realestate/pdf/sustainability-today.pdf (September 2010).

Corps C. 2005. "Green Value: Green Buildings, Growing Assets." The Royal Institution of Chartered Surveyors (RCIS), Victoria, British Columbia, Canada. Available from www.metrovancouver.org/about/.../greenvaluecasestudies1.pdf (September 2010).

Eichholtz P, N Kok, and JM Quigley. 2009. "Doing Well by Doing Good? Green Office Buildings.” Working Paper No. W08-001, Working Paper Series, Berkeley Program on Housing and Urban Policy, Institute of Business and Economic Research, University of California, Berkeley. Available from http://escholarship.org/uc/item/507394s4 (September 2010). 
Eichholtz P, N Kok, and JM Quigley. 2009. Why Do Companies Rent Green? Real Property and Corporate Social Responsibility. Energy Policy and Economics 024, UC Energy Institute, Berkeley, California. Available from

http://www.rics.org/site/scripts/download_info.aspx?fileID=5071\&categoryID=523 (September 2010).

Fuerst F and P McAllister. 2009. "New Evidence on the Green Building Rent and Price Premium." Presented to the American Real Estate Society, Monterey, California, April 3, 2009. Henley Business School, School of Real Estate \& Planning, Reading University, United Kingdom. Available from http://www.henley.reading.ac.uk/rep/fulltxt/0709.pdf (September 2010)

Fuerst F and PM McAllister. 2008. Green Noise or Green Value? Measuring the Price Effects of Environmental Certification in Commercial Buildings. School of Real Estate and Planning, Henley Business School, University of Reading, United Kingdom. Available from http://mpra.ub.unimuenchen.de/16625/ (September 2010).

Houser T. 2009. The Economics of Energy Efficiency in Buildings. Policy Brief PB09-17, The Peterson Institute for International Economics, Washington, D.C. Available from http://www.petersoninstitute.org/publications/interstitial.cfm?ResearchID=1198 (September 2010).

Jones Lang LaSalle. 2009. "A Landmark Sustainability Program for the Empire State Building." White paper (Clinton Climate Initiative, Rocky Mountain Institute, Anthony Malkin, Owner Empire State Building, Johnson Controls). New York, New York, Boulder, Colorado, and Milwaukee, Wisconsin. Available from http://www.esbsustainability.com/SocMe/Content/Files/ESB White Paper_061809.pdf (September 2010).

Kats G, M James, S Apfelbaum, T Darden, D Farr, RF Fox Jr., L Frank, J Laitner, C Leinberger, GJ Saulson, S Williams, and J Braman. 2009. Greening Buildings and Communities: Costs and Benefits. Good Energies, New York, New York. Available from http://www.goodenergies.com/presentation (September 2010).

Lucuik M, W Trusty, N Larsson, and R Charette. 2005. "A Business Case for Green Buildings in Canada." Presented to Industry Canada, Report No. 2052223.00, Morrison Hershfield, Ottawa, Ontario, Canada. Available from http://www.cagbc.org/uploads/A Business Case for Green Bldgs in Canada.pdf (September 2010).

Lutzenhiser L, N Woolsey Biggart, R Kunkle, TD Beamish, and T Burr. 2001. Market Structure and Energy Efficiency: The Case of New Commercial Buildings. Washington State University, Pullman, Washington, and the University of California, Davis Institute for Governmental Affairs, Davis, California. Available from http://ciee-dev.eecs.berkeley.edu/pubs/ref_behavior.html (September 2010).

McCabe M. 2010. Practical Greening - The Bottom Line on Sustainable Property Development, Investment and Financing. Peppertree Press, Sarasota, Florida. Available from http://www.practicalgreening.com (September 2010).

McGraw Hill Construction. 2008. Green Outlook 2009: Trends Driving Change. McGraw Hill Construction, Research and Analytics. Bedford, Massachusetts. Available from http://www.analytics.construction.com (September 2010). 
McGraw Hill Construction. 2008. Smart Market Report: Commercial and Institutional Green Building. McGraw Hill Construction, Research and Analytics. Bedford, Massachusetts. Available from http://www.greensource.construction.com/resources/smartmarket (September 2010).

Miller M. 2009. Leading Example for Energy Efficiency, Retrofitting America's Favorite Skyscraper, The Empire State Building, a Leading Example for Energy Efficiency. Rocky Mountain Institute, Boulder, Colorado. Available from http://esbsustainability.com/SocMe/?id=241\&pid=237\&sid=241 (September 2010).

Miller N, J Spivey, and A Florance. 2008. "Does Green Pay Off?” White Paper. University of San Diego and CoStar. San Diego, California. Available from http://www.sandiego.edu/business/documents/USDEconofBeingGreen.pdf (September 2010).

Miller NG and D Pogue. 2009. Do Green Buildings Make Dollars and Sense? USD-BMC Working Paper 09-11, Draft. Burnham-Moores Center for Real Estate, University of San Diego, and CB Richard Ellis (CBRE), San Jose, California. Available from http://www.cbre.com/USA/Sustainability/Envirometrics.htm (September 2010).

Muldavin S. 2008. Quantifying “Green” Value: Assessing the Applicability of the CoStar Studies. Green Building Finance Consortium, San Rafael, California.

Muldavin S. 2009. "Ten Principles for Sustainable Property Underwriting \& Valuation. RICS Property World, pp. 15-18. San Rafael, California. Available from http://www.ricsamericas.org/files/editor/file/Property World/PW Fall09 Files/Muldavin-Ten Principles for Sustainable Property PW Fal109.pdf (September 2010).

Muldavin SR. 2010. Value Beyond Cost Savings: How to Underwrite Sustainable Properties. Green Building Finance Consortium, The Muldavin Company, Inc., San Rafael, California. Available from http://www.greenbuildingfc.com/ (September 2010).

Neill SP. 2009. Energy Efficiency Lease Guidance. Natural Resources Defense Council, The Green Lease Forum, New York, New York. Available from http://www.cycle-

7downloads.com/Downloads_files/Energy Efficiency Lease Guidance in EDNY.pdf (September 2010).

Paevere P and S Brown. 2008. Indoor Environment Quality and Occupant Productivity in the CH2 Building: Post-Occupancy Summary. Report No. USP2007/23, Commonwealth Scientific and Industrial Research Organisation (CSIRO), Highett, VIC, Australia.

Peterson K and R Gammill. 2010. "The Economics of Sustainability in Commercial Real Estate." Prepared for the IFMA Foundation by Sustainability Roundtable, Inc. and Allonhill. Houston, Texas. Available from http://www.ifmafoundation.org/documents/public/EcoofSustainability.pdf (September 2010). 
Pivo G and JD Fisher. 2009. "Investment Returns from Responsible Property Investments: Energy Efficient, Transit Oriented and Urban Regeneration Office Properties in the US from 1998-2008." Working Paper, Responsible Property Investing Center, Boston College and University of Arizona, Benecki Center for Real Estate Studies, Indiana University. Tucson, Arizona, and Bloomington, Indiana. Available from http://www.u.arizona.edu/ gpivo/Pivo_Fisher_Investment Returns from RPI 3_3_09.pdf (September 2010).

Portland Development Commission. 2007. "A Green Building Primer and the Business Case for Constructing LEED Certified Buildings.” Portland, Oregon.

REO Research and F\&C Investments. 2009. "Sustainable Real Estate Securities - How Solid are Your Foundations?" London, England, United Kingdom. Available from http://www.fundnets.net/fn_filelibrary//file/

Sustainable_Real_Estate_Securities_How_solid_are_your_foundations_December_2009.pdf (September 2010).

Thompson B and L Bank. 2006. "The Perception of Risk in Performance-Based Design of Buildings." American Society of Civil Engineers, pp. 1-15, DOI 10.1061/40798(190)46.

Turner C and M Frankel. 2008. Energy Performance of LEED ${ }^{\circledR}$ for New Construction Buildings, Final Report. Prepared for U.S. Green Building Council, Brendan Owens, Washington, D.C. Available from http://www.newbuildings.org/downloads/Energy_Performance_of_LEED-NC_Buildings-Final_3-408b.pdf (September 2010).

Turner Construction Company. 2008. Turner 2008 Green Market Barometer. Turner Construction Company. New York, New York. Available from http://www.turnerconstruction.com/greenbuildings/content.asp?d=6552 (September 2010).

Webb D. 2009. "Toward Sustainable Finance: The Trouble with Asset Values." RICS Property World, pp. 9-11. Available from http://www.ricsamericas.org/files/editor/file/Property World/PW Fall09 Files/Webb-Toward Sustainable Finance PW Fal109.pdf (September 2010).

World Business Council for Sustainable Development (WBCSD). 2009. Transforming the Market: Energy Efficiency in Buildings. Energy Efficiency in Buildings Project, Washington, D.C. Available from http://www.wbcsd.org/Plugins/DocSearch/details.asp?DocTypeId=25\&ObjectId=MzQyMDQ (September 2010).

\section{B.2 Financial Mechanisms and Finance}

Brown M. 2009. "Paying for Energy Upgrades Through Utility Bills." State Energy Efficiency Polices, Options and Lessons Learned, A Series of Briefs, Brief \#3, Alliance to Save Energy, Washington, D.C. Available from http://ase.org/content/article/detail/5476 (September 2010).

Creyls J, A Derkach, S Nyquist, K Ostrowski, and J Stephenson. 2007. Reducing U.S. Greenhouse Gas Emission: How Much at What Cost? U.S. Greenhouse Gas Abatement Mapping Initiative Executive Report, McKinsey \& Company, New York, New York. Available from http://www.mckinsey.com/clientservice/sustainability/greenhousegas.asp (September 2010). 
Earth Advantage Institute and Conservation Services Group for the Energy Trust of Oregon. 2009. Energy Performance Score 2008 Pilot: Findings and Recommendations Report. Portland, Oregon. Available from http://www.earthadvantage.org/eps_2008_pilot_report_fnl1x.pdf (September 2010).

Equilibrium Capital Group LLC. 2010. Sustainability Investment Report, Energy Efficiency: Turning Negawatts into Marketable Securities. Portland, Oregon. Available from http://quuh.files.wordpress.com (September 2010).

Fuller MC, C Kunkel, and DM Kammen. 2009. Guide to Energy Efficiency \& Renewable Energy Financing Districts for Local Governments. Renewable and Appropriate Energy Laboratory (RAEL), University of California, Berkeley. Available from http://rael.berkeley.edu/node/446 (September 2010).

Granade HC, J Creyts, A Derkach, P Farese, S Nyquist, and K Ostrowski. 2009. Unlocking Energy Efficiency in the U.S. Economy. McKinsey Global Energy and Materials, New York, New York. Available from http://www.mckinsey.com/clientservice/electricpowernaturalgas/US_energy_efficiency/ (September 2010).

Hendricks B, B Campbell, and P Goodale. 2010. Efficiency Works: Creating Good Jobs and New Markets Through Energy Efficiency. Center for American Progress and Equilibrium Resource Management Corporation, Washington, D.C. Available from http://www.americanprogress.org/issues/2010/08/pdf/good_jobs_new_markets.pdf (September 2010).

Hinkle B and D Kenny. 2010. Energy Efficiency Paying the Way: New Financing Strategies Remove First-Cost Hurdles. CalCEF Innovations White Paper (California Clean Energy Fund) San Francisco, California. Available from http://www.calcef.org/innovations/activities/CALCEF-WP-EE-2010.pdf (September 2010).

Hinkle B and S Schiller. 2009. New Business Models for Energy Efficiency. CalCEF Innovations White Paper, San Francisco, California. Available from http://www.calcef.org/innovations/activities/NewBusModelforEE_CalCEF-March2009.pdf (September 2010).

Kats G. 2010. Greening Our Built World: Costs, Benefits, and Strategies. Island Press, Washington, D.C.

Kok N, P Eichholtz, R Bauer, and P Peneda. 2010. Environmental Performance: A Global Perspective on Commercial Real Estate. The European Centre for Corporate Engagement, Maastricht University School of Business and Economics, Netherlands. Available from http://www.corporateengagement.com/images/Survey Environmental Performance.pdf (September 2010).

Lovins A. 2007. Advanced Energy Efficiency: Lecture 1-Buildings; Lecture 4: Implementation and Lecture 5: Implications. Stanford University Energy Lectures. Palo Alto, California. Available from http://www.rmi.org/rmi/Stanford+Energy+Lectures (September 2010). 
MacLean J. 2008. Mainstreaming Environmental Finance Markets (I) - Small-Scale Energy Efficiency and Renewable Energy Finance. Energy Efficiency Finance Corporation. Presented at the KfW Financial Sector Development Symposium. Berlin, Germany. Available from http://www.kfwentwicklungsbank.de/EN_Home/Sectors/Financial_system_development/Events/Symposium_2008/Pdf_d ocuments_-_symposium_2008/Session_3_Expert_Paper_Final_Version.pdf (September 2010).

Maldonado E. 2009. The European Union Energy Performance Directive, 2009 Feb. Presentation delivered to RESNET Building Performance Conference. New Orleans, Louisiana. Available from http://www.resnet.us/conference/2009/presentations/maldonado.pdf (September 2010).

McKinsey \& Co. 2009. Pathways to a Low-Carbon Economy - Version 2 of the Global Greenhouse Gas Abatement Cost Curve. McKinsey \& Company, New York. Available from http://rfflibrary.wordpress.com/2009/01/26/pathways-to-a-low-carbon-economy-version-2-of-the-globalgreenhouse-gas-abatement-cost-curve/ (September 2010).

Moore E, A Robbins, E Rowe, S Moersfelder, N O’Neil, B Lynch, N Hillis and M Frankel. 2010. "Small Buildings, Big Savings: Prescriptive Solutions for Energy Efficiency and Green Certification in Small Commercial Buildings." First presented at the ACEEE Summer Study 2010. Portland Energy Conservation, Inc. (PECI), Energy Trust of Oregon, Earth Advantage Institute and the New Buildings Institute, Portland, Oregon. Available at http://www.peci.org/documents/whitepaper/PECI2023_EMoore_0910.pdf(September 2010).

Selkowitz S, J Granderson, P Haves, P Mathew, and J Harris. 2008. Scale Matters: An Action Plan for Realizing Sector-Wide “Zero-Energy” Performance Goals in Commercial Buildings. Lawrence Berkeley National Laboratory, Berkeley, California. Available at http://eec.ucdavis.edu/ACEEE/2008/data/papers/10_673.pdf. (September 2010).

The National Resources Defense Council; PACE Now; Renewable Funding, LCC; and The Vote Solar Initiative. 2010. "Property Assessed Clean Energy ("PACE") White Paper: Helping Achieve Environmental Sustainability and Energy Independence, Improving Homeowner Cash Flow and Credit Profile, Protecting Mortgage Lenders and Creating Jobs." New York, New York. Available from http://pacenow.org (September 2010).

Wood L and R Risser. 2009. Making the Business of Energy Efficiency Both Scalable and Sustainable. Policy Brief 09-01, The Brookings Institution, Washington, D.C. Available from http://www.brookings.edu/papers/2009/04_energy_efficiency_wood.aspx (September 2010).

World Business Council for Sustainable Development. 2008. Energy Efficiency in Buildings, Business Realities and Opportunities: Facts and Trends. World Business Council for Sustainable Development (WBCSD), Energy Efficiency in Buildings Project. Geneva, Switzerland. Available from http://www.wbcsd.org/plugins/DocSearch/details.asp?txtDocTitle=facts\%20and\%20trends\&txtDocText= facts $\% 20$ and $\% 20$ trends\&DocTypeId $=-$

1\&ObjectId=MjU5MTE\&URLBack=result\%2Easp\%3FtxtDocTitle\%3Dfacts + and + trends\%26txtDocTex $\mathrm{t} \% 3 \mathrm{Dfacts}+$ and + trends\%26DocTypeId\%3D\%2D1\%26SortOrder\%3D\%26CurPage\%3D2 (September 2010). 


\section{B.3 Cost Analysis - Energy Efficiency and Sustainability}

Augenbroe G, D Castro, and K Ramkrishnan. 2009. "Decision Model for Energy Performance Improvements in Existing Buildings.” Journal of Engineering, Design and Technology 7(1):21-36.

DB Climate Change Advisors. 2010. Investing in Climate Change 2010: A Strategic Asset Allocation Perspective. Deutche Bank Group, New York.

DOE - U.S. Department of Energy. 2004. "Building Technologies Program Buildings Database." Energy Efficiency and Renewable Energy, Washington, D.C. Available from http://eere.buildinggreen.com/index.cfm (September 2010).

ENR - Engineering News Record. 2007. Square Foot Costbook 2008 Edition. Design and Construction Resources, McGraw Hill Construction. New York, New York.

GSA - U.S. General Services Administration. 2004. GSA LEED ${ }^{\circledR}$ Cost Study, Final Report. Steven Winter Associates, Inc., Norwalk, Connecticut, and Washington, D.C.

International Facility Management Association. 2009. Operations and Maintenance Benchmarks. Research Report \#32, Houston, Texas.

Kats G, L Alevantis, A Berman, E Mills, and J Perlman. 2003. The Costs and Financial Benefits of Green Buildings: A Report to California's Sustainable Building Task Force. Capital-E Analytics. Sacramento, California.

Matthiessen LF and P Morris. 2004. Costing Green: A Comprehensive Costing Database and Budgeting Methodology. Davis Langdon, Sacramento, CA and Los Angeles, California. Available from http://www.davislangdon.com/USA/Research/ResearchFinder/2004-Costing-Green-A-ComprehensiveCost-Database-and-Budgeting-Methodology/ (September 2010).

Matthiessen LF and P Morris. 2007. The Cost of Green Revisited: Reexamining the Feasibility and Cost Impact of Sustainable Design in the Light of Increased Market Adoption. Davis Langdon, Sacramento, California, and Los Angeles, California. Available from http://www.davislangdon.com/USA/Research/ResearchFinder/2007-The-Cost-of-Green-Revisited/ (September 2010).

McGraw Hill Construction. 2009. Smart Market Report: Green Building Retrofit and Renovation. McGraw Hill Construction, Research and Analytics. Bedford, Massachusetts.

RS Means. 2006. Green Building: Project Planning and Cost Estimating, 2nd Edition. 474 pp. Kingston, Massachusetts. Available from http://rsmeans.reedconstructiondata.com/CostBooks.aspx (September 2010).

RS Means. 2010. Building Construction Cost Data 2010 Book. 68th Annual Edition. Kingston, Massachusetts. Available from http://rsmeans.reedconstructiondata.com/CostBooks.aspx (September 2010). 
Seppänen O and WJ Fisk. 2003. A Conceptual Model to Estimate Cost Effectiveness of the Indoor Environment Improvements. Lawrence Berkeley National Laboratory, Berkeley, California. Available from http://escholarship.org/uc/item/3nv9t304 (September 2010).

Smith K. 2009. Cost of Green Analysis for Affordable Housing in Seattle and Portland. Davis Langdon, Seattle, Washington. Available from http://www.davislangdon.com/USA/Research/ResearchFinder/2009-Cost-of-Green-Analysis-forAffordable-Housing-in-Portland-and-Seattle/ (September 2010).

Syal MG, S Mago, and D Moody. 2007. "Impact of LEED-NC Credits on Contractors." Journal of Architectural Engineering 13(4):174. Available from http://dx.doi.org/10.1061/(ASCE)10760431(2007)13:4(174) (September 2010).

Syphers G, M Baum, D Bouton, and W Sullens. 2003. Managing the Cost of Green Buildings, K-12 Public Schools, Research Laboratories, Public Libraries, Multi-Family Affordable Housing. State of California's Sustainable Building Task Force, California State and Consumer Services Agency, and Alameda County Waste Management Authority, Oakland, California.

U.S. Department of Energy. August 2003. The Business Case for Sustainable Design in Federal Facilities. Office of Energy Efficiency and Renewable Energy, Federal Energy Management Program, Washington, D.C.

U.S. Department of Energy. October 2003. The Business Case for Sustainable Design in Federal Facilities: Resource Document. Office of Energy Efficiency and Renewable Energy, Federal Energy Management Program, Washington, D.C.

Vaidya P, L Greden, D Eijadi, T McDougall, and R Cole. "Integrated Cost-Estimation Methodology to Support High-Performance Building Design.” Energy Efficiency 2(1):69-85. Berkeley, California. Available from http://dx.doi.org/10.1007/s12053-008-9028-4 (September 2010).

Warnke DM. 2004. Making the Business Case for Sustainable Design in the Department of Defense. U.S. Department of the Air Force Air University, Air Force Institute of Technology, Wright-Patterson Air Force Base, Ohio. Available from http://oai.dtic.mil/oai/oai?\&verb=getRecord\&metadataPrefix=html\&identifier=ADA423102 (September 2010).

Whitestone Research. 2009. The Whitestone Facility Maintenance and Repair Cost Reference, 2009-2010. 480 pp. Santa Barbara, California. [ISBN: 978-0-9669629-9-0?]

Whitestone Research. 2009. The Whitestone Facility Operations Cost Reference. 304 pp. Santa Barbara, California. [ISBN: 978-0-9840642-0-5?] 


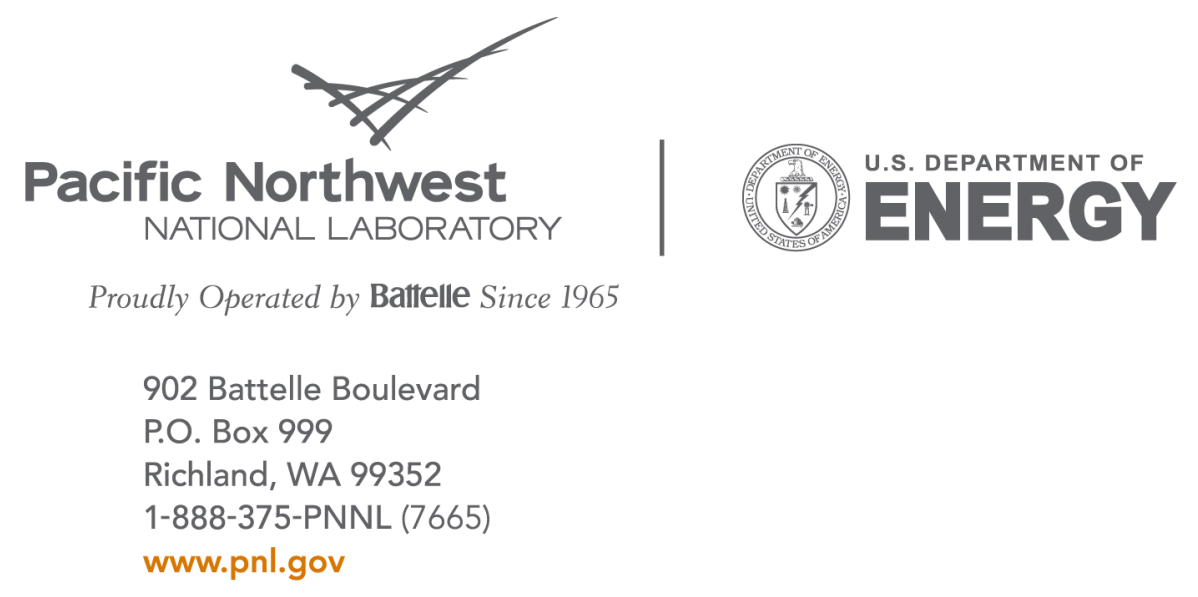

